\title{
Texture analysis in colorectal liver metastases
}

Citation for published version (APA):

Beckers, R. C. J. (2018). Texture analysis in colorectal liver metastases: A potential imaging biomarker. [Doctoral Thesis, Maastricht University]. Optima Grafische Communicatie. https://doi.org/10.26481/dis.20180712rb

Document status and date:

Published: 01/01/2018

DOI:

10.26481/dis.20180712rb

Document Version:

Publisher's PDF, also known as Version of record

\section{Please check the document version of this publication:}

- A submitted manuscript is the version of the article upon submission and before peer-review. There can be important differences between the submitted version and the official published version of record.

People interested in the research are advised to contact the author for the final version of the publication, or visit the DOI to the publisher's website.

- The final author version and the galley proof are versions of the publication after peer review.

- The final published version features the final layout of the paper including the volume, issue and page numbers.

Link to publication

\footnotetext{
General rights rights.

- You may freely distribute the URL identifying the publication in the public portal. please follow below link for the End User Agreement:

www.umlib.nl/taverne-license

Take down policy

If you believe that this document breaches copyright please contact us at:

repository@maastrichtuniversity.nl

providing details and we will investigate your claim.
}

Copyright and moral rights for the publications made accessible in the public portal are retained by the authors and/or other copyright owners and it is a condition of accessing publications that users recognise and abide by the legal requirements associated with these

- Users may download and print one copy of any publication from the public portal for the purpose of private study or research.

- You may not further distribute the material or use it for any profit-making activity or commercial gain

If the publication is distributed under the terms of Article $25 \mathrm{fa}$ of the Dutch Copyright Act, indicated by the "Taverne" license above, 


\section{Texture analysis in \\ colorectal liver metastases}

A potential imaging biomarker

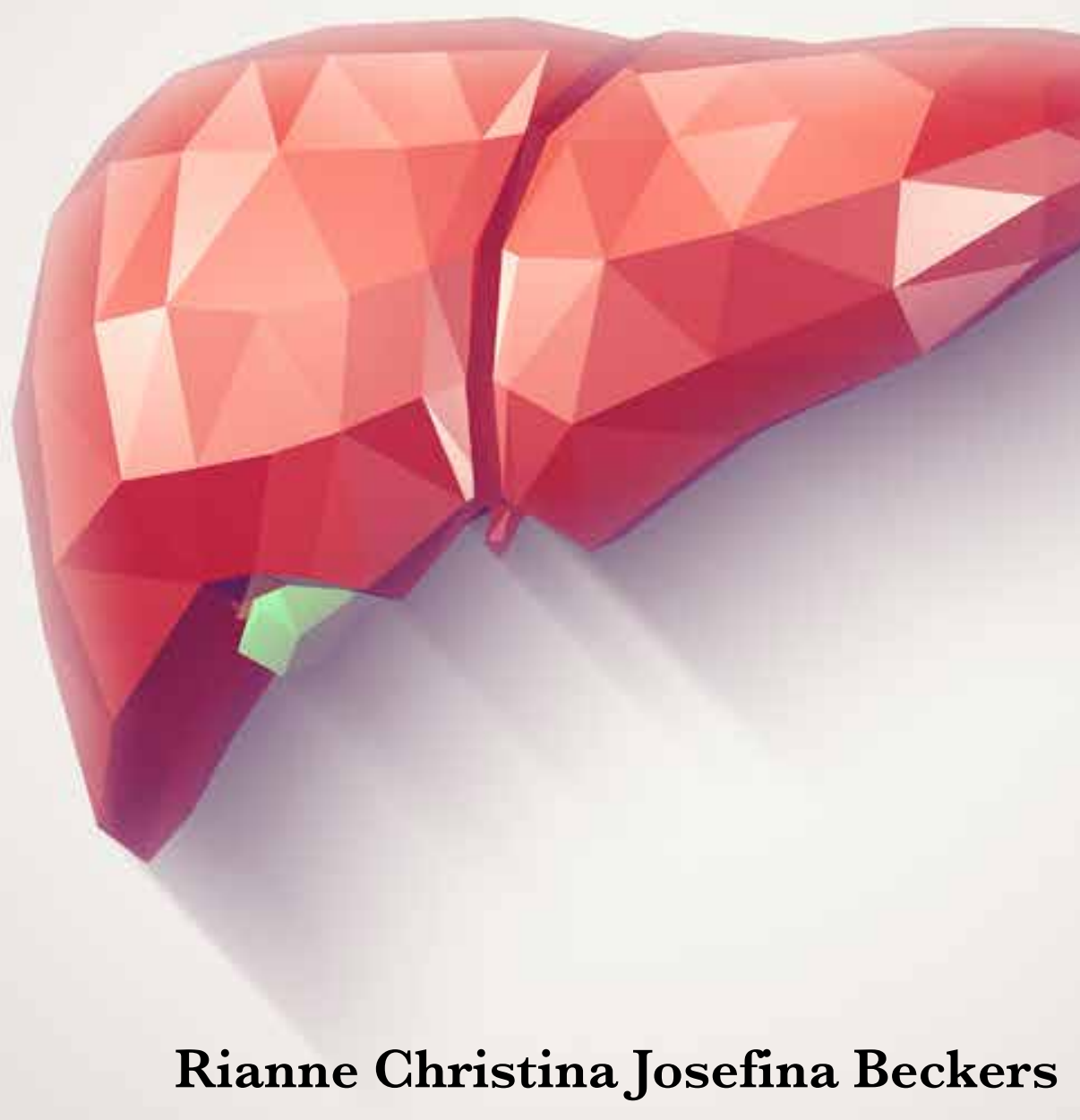




\section{Texture analysis in colorectal liver metastases}

A potential imaging biomarker

Rianne Christina Josefina Beckers 
ISBN: 978-94-6361-122-0

Lay-out \& Coverdesign:
concept:
R.J.C. Beckers
design \& lay-out:
E. van Kempen | Spinning Wheels multimedia

Printed and published by: Optima

(C) 2018 R.G.J. Beckers

All rights reserved. No part of this publication may be reproduced, stored in a retrieval database or published in any form by any means, electronic, mechanical or photocopying, recording or otherwise, without the prior written permission of the author, or, when appropriate, of the publishers of the publications. 


\section{TEXTURE ANALYSIS IN GOLOREGTAL LIVER METASTASES}

\section{A potential imaging biomarker}

\section{PROEFSGHRIFT}

Ter verkrijging van de graad van doctor aan de

Universiteit Maastricht,

op gezag van de Rector Magnificus, Prof.dr. Rianne M. Letschert

volgens het besluit van het College van Decanen, in het openbaar te verdedigen

op donderdag 12 juli 2018 om 14.00 uur

door

Rianne Christina Josefina Beckers 


\section{Promotores}

Prof. Dr. R.G.H. Beets-Tan

Prof. Dr. G.L. Beets

\section{Copromotor}

Dr. D.M.J. Lambregts

\section{Beoordelingscommissie}

Prof. Dr. A.A.M. Masclee (voorzitter)

Prof. Dr. W.H. Backes

Prof. Dr. R.C. Dresen (UZ Leuven, België)

Prof. Dr. U.A. van der Heide (Nederlands Kanker Instituut - Antoni van

Leeuwenhoek, Amsterdam)

Prof. Dr. U.P. Neumann (Uniklinik RWTH Aachen, Duitsland / MUMC+, Maastricht) 


\section{Thesis overview}

Chapter $1 \quad$ General introduction

Chapter 2 Beckers R, Lambregts D.... Beets-Tan R, Maas M. Advanced Imaging to predict response to chemotherapy in colorectal liver metastases - a systematic review Published in HPB 2017 (Nov 28, Epub ahead of print)

Chapter 3

Beckers R, Lambregts D.... Beets-Tan R. Whole liver CT texture analysis to predict the development of colorectal liver metastases - a multicentre study

Published in Eur $\mathcal{F}$ Radiol 2017;92:64-71

Chapter 4

Beckers R, Beets-Tan R....Lambregts D. Whole volume versus segmental CT texture analysis of the liver to assess metachronous colorectal liver metastases

Published in Abdom Radiol 2017;42:2639-2645

Chapter 5

Beckers R, Trebeschi S.... Beets-Tan R, Lambregts D. CT texture analysis in colorectal liver metastases and the surrounding liver parenchyma and its potential as an imaging biomarker of disease aggressiveness, response and survival

Published in Eur F Radiol 2018;102:15-21

Chapter 6

Beckers R, Trebeschi S.... Beets-Tan R, Lambregts D. Quantitative imaging of the liver in colorectal cancer patients: a comparison between diffusion-weighted MRI and CT texture analysis

Under review

Chapter 7

Chapter 8

Chapter 9

Chapter 10

Chapter 11

Chapter 12
General discussion

Summary / Samenvatting

Valorisation Addendum

List of publications

Dankwoord

Curriculum Vitae 


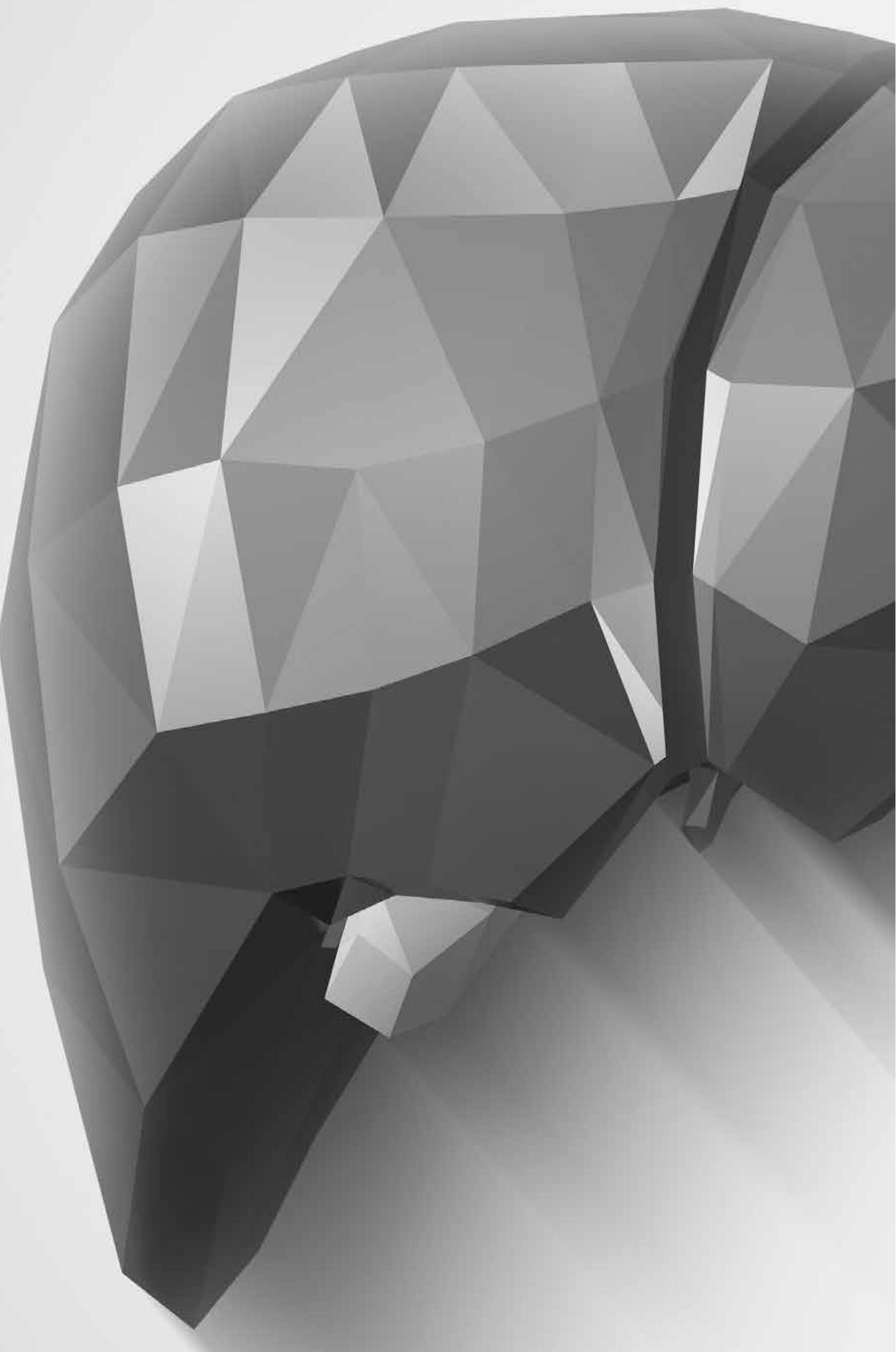




\section{General introduction}

Colorectal cancer (CRC) is the most common form of cancer in The Netherlands, with 15.550 new cases in $2015^{1}$. Incidence is expected to rise to 17.000 new cases in 2020 because of the implementation of the nationwide screening program, the growing incidence (especially in men) and the growing and ageing population $^{1}$. Nowadays, GRC is the second-most common cause of cancer-related death in Western countries ${ }^{2,3}$. Mortality is mainly related to the presence of metastatic disease. The liver is the most frequent and often unique site of metastasis in CRC, with metastases occurring both at the time of diagnosis (synchronous) in $14.5 \%$ as well as within five years after surgery on the primary tumour (metachronous) in $3.7 \%$ to up to $30.4 \%$.

In the last two decades, treatment of metastatic GRC has rapidly evolved with the availability of more effective chemotherapy regimens and more targeted therapies such as monoclonal antibodies (e.g. bevacizumab, cetuximab and panitumumab) that target the endothelial growth factor receptor or epidermal growth factor receptor $^{5}$. Moreover, local treatment options have evolved with the introduction of minimally invasive techniques such as local ablative therapies (radiofrequency and microwave ablation) and chemo- and radioembolization techniques. As a result of these developments, median overall survival rates have improved considerably with reported 5-year overall survival rates of 30-60\% for radically treated patients in recent studies compared to $9-16 \%$ in studies from $1999-2010^{4,6,7}$.

These recent advances in the treatment of colorectal liver metastases (CRLM) have led to an increasing demand for more precise diagnostic imaging techniques to help guide and optimise personalised patient management. Although certainly not (yet) standard in all clinics, an important development is the increasing use of MRI to stage the liver. Particularly MRI with liver-specific contrast has proven superior sensitivity to detect even very small liver metastases, resulting in optimised treatment planning ${ }^{8,9}$. Nevertheless, in most hospitals to date, CT (computed tomography) remains the main 'workhorse' for the staging of CRC, also because it allows simultaneous staging of other potential metastatic sites including the lungs and peritoneal cavity ${ }^{9}$.

Apart from detecting and determining the extent of the metastatic disease, there are two important clinical issues in the imaging of CRLM: [1] analysing the response to systemic therapy and [2] predicting the course of the disease. Approximately $14.5 \%$ of patients initially present without metastases but develop metachronous liver metastases somewhere during the course of their disease. We 
have yet to find the tools to help us determine which factors best predict the course of the disease and consequently to help us identify which patients are at risk. Moreover, once the metastatic disease is present it remains unclear which patients will likely show a good response to treatment and which patients will not. Here might be a window of opportunities because improved knowledge on these issues could help us to further tailor treatment according to a patient's individual risk profile. Imaging could play an important role in this regard.

So far, the mainstay of imaging evaluation has been to assess tumour morphology (e.g. shape, signal) and size, for example in the Response Evaluation Criteria in Solid Tumours (RECIST), one of the most widely used imaging assessment techniques to evaluate response ${ }^{10}$. In other words, we have so far mainly focussed on things that can be appreciated by the 'naked eye'. There is, however, much more information 'hidden' in images that could potentially provide us with more in-depth knowledge about the underlying tumour biology. This information can be distilled when we look at images with more sophisticated image post-processing methods.

Several methods of image post-processing and quantification exist, varying from relatively simple statistical methods such as histogram analysis of signal values within an image to more novel methods like Radiomics, which extract large amounts of imaging features using more advanced data-quantification algorithms ${ }^{11}$. Within a broad spectrum of imaging features used in Radiomics, features related to image "texture" appears to be amongst the most promising ${ }^{12}$. Image texture refers to the spatial distribution of signals intensities within a selected region of an image, for example within a tumour on $\mathrm{CT}^{13}$. When this spatial distribution is more irregular, this is associated with a more heterogeneous underlying tissue architecture ${ }^{12}$. Tumours with a high heterogeneity have been shown to be associated with a more aggressive biology leading to poorer prognosis and treatment resistance. This heterogeneity may be captured by quantitative features derived from image texture analysis and therefore may have potential to act as imaging biomarkers to predict response and outcome ${ }^{12,14-16}$. The major additional benefit is that texture features can 'freely' be derived from any routinely acquired clinical imaging examination (for example CT or MRI) without the need for extra acquisitions or sophisticated image acquisition techniques.

So far most experience exists with texture analysis using CT data. At the start of this thesis project, evidence for CT texture analysis in oncology was scarce but promising. In a small number of (technical) pilot studies in relatively small patient cohorts (typically 10 to up to 50 patients) it was shown that CT texture 
features from oesophageal tumours, primary and metastatic liver tumours, metastasized kidney tumours and colorectal malignancies hold promise to predict treatment response, disease progression and long-term outcome ${ }^{17-23}$. In colorectal liver metastases in specific, the group of Ganeshan et al were the first to show a potential benefit for texture analysis to predict disease outcome ${ }^{24-26}$. They also showed various correlations between liver texture features and related measures of disease such as hepatic perfusion and the presence of nodal and hepatic metastases $^{27}$. Whether there could be any meaningful role for CT texture analysis in the clinical management of patients with colorectal liver metastases remains to be determined by further research and was the main focus of this thesis.

\section{Aims of this thesis}

The aims of this thesis are to review current evidence on the role of imaging in the assessment of colorectal liver metastases and to investigate what can be the potential added clinical role of novel more advanced image quantification techniques, in particular, textural analysis.

The main study questions are:

1. What is the diagnostic performance of currently available imaging techniques to assess response to of colorectal liver metastases to chemotherapy?

2. What is the added value of CT texture analysis for the assessment of colorectal liver metastases? 


\section{Outline of this thesis}

Chapter 2 presents a comprehensive overview of current literature on the potential of different imaging modalities and techniques to predict the response to chemotherapy in colorectal liver metastases.

In Chapter 3, we conducted a multicentre study to investigate whether whole liver CT texture analysis is capable of predicting the presence of metastatic liver disease and the development of metachronous colorectal liver metastases.

In Chapter 4, we aimed to improve our method of texture analyses by investigating whether performing a segmental liver texture analysis instead of a whole liver approach has added benefit to predict metachronous disease.

Chapter 5 evaluates more in depth the relation between the CT texture of colorectal liver metastases and the surrounding liver parenchyma in order to get a better insight into the underlying mechanism of disease. The aim was to assess if the ratio between the texture of the metastases and background liver can be of added value as a predictive or prognostic imaging marker.

Finally, in Chapter 6, we performed a pilot study to investigate potential correlations between CT texture features of the liver and corresponding quantitative imaging characteristics derived from liver diffusion-weighted MRI in patients with colorectal cancer. 


\section{References}

1. Cijfers over kanker. Integraal Kankercentrum Nederland, 2015.

2. Jemal A, Bray F, Genter MM, Ferlay J, Ward E and Forman D. Global cancer statistics. CA: a cancer journal for clinicians. 2011; 61: 69-90.

3. Edwards BK, Noone AM, Mariotto AB, et al. Annual Report to the Nation on the status of cancer, 1975-2010, featuring prevalence of comorbidity and impact on survival among persons with lung, colorectal, breast, or prostate cancer. Cancer. 2014; 120: $1290-314$.

4. Manfredi S, Lepage C, Hatem C, Coatmeur O, Faivre J and Bouvier AM. Epidemiology and management of liver metastases from colorectal cancer. Annals of surgery. 2006; 244: 254-9.

5. Adam R, Delvart V, Pascal G, et al. Rescue surgery for unresectable colorectal liver metastases downstaged by chemotherapy: a model to predict long-term survival. Annals of surgery. 2004; 240: 644-58.

6. Kopetz S, Chang GJ, Overman MJ, et al. Improved survival in metastatic colorectal cancer is associated with adoption of hepatic resection and improved chemotherapy. Fournal of clinical oncology : official journal of the American Society of Clinical Oncology. 2009; 27: 3677-83.

7. Kanas GP, Taylor A, Primrose JN, et al. Survival after liver resection in metastatic colorectal cancer: review and meta-analysis of prognostic factors. Clinical epidemiology. 2012; 4: 283-301.

8. Grand DJ, Beland M, Noto RB and Mayo-Smith W. Optimum imaging of colorectal metastases. Fournal of surgical oncology. 2010; 102: 909-13.

9. Bipat S, Niekel MC, Comans EF, et al. Imaging modalities for the staging of patients with colorectal cancer. The Netherlands journal of medicine. 2012; 70: 26-34.

10. Eisenhauer E, Therasse P, Bogaerts J, et al. New response evaluation criteria in solid tumours: revised RECIST guideline (version 1.1). European journal of cancer. 2009; 45: 228-47.

11. Lambin P, Rios-Velazquez E, Leijenaar R, et al. Radiomics: extracting more information from medical images using advanced feature analysis. European journal of cancer 2012; $\mathbf{4 8}(4)$ : 441-6.

12. Davnall F, Yip CS, Ljungqvist G, et al. Assessment of tumor heterogeneity: an emerging imaging tool for clinical practice? Insights into imaging 2012; 3(6): 573-89.

13. Ganeshan B and Miles KA. Quantifying tumour heterogeneity with CT. Cancer imaging : the official publication of the International Cancer Imaging Society. 2013; 13: 140-9.

14. Hockel M, Knoop C, Schlenger K, et al. Intratumoral pO2 predicts survival in advanced cancer of the uterine cervix. Radiotherapy and oncology : journal of the European Society for Therapeutic Radiology and Oncology. 1993; 26: 45-50.

15. Hockel M, Schlenger K, Aral B, Mitze M, Schaffer U and Vaupel P. Association between tumor hypoxia and malignant progression in advanced cancer of the uterine cervix. Cancer research. 1996; 56: 4509-15.

16. Yang Z, Tang LH and Klimstra DS. Effect of tumor heterogeneity on the assessment of Ki67 labeling index in well-differentiated neuroendocrine tumors metastatic to the liver: implications for prognostic stratification. The American journal of surgical pathology. 2011; 35: 853-60.

17. Bezy-Wendling J, Kretowski M, Rolland Y and Le Bidon W. Toward a better un- 
derstanding of texture in vascular CT scan simulated images. IEEE transactions on bio-medical engineering. 2001; 48: 120-4.

18. Ganeshan B, Abaleke S, Young RC, Chatwin CR and Miles KA. Texture analysis of non-small cell lung cancer on unenhanced computed tomography: initial evidence for a relationship with tumour glucose metabolism and stage. Cancer imaging : the offcial publication of the International Cancer Imaging Society. 2010; 10: 137-43.

19. Goh V, Ganeshan B, Nathan P, Juttla JK, Vinayan A and Miles KA. Assessment of response to tyrosine kinase inhibitors in metastatic renal cell cancer: CT texture as a predictive biomarker. Radiology. 2011; 261: 165-71.

20. Ganeshan B, Panayiotou E, Burnand K, Dizdarevic S and Miles K. Tumour heterogeneity in non-small cell lung carcinoma assessed by CT texture analysis: a potential marker of survival. European radiology. 2012; 22: 796-802.

21. Ganeshan B, Skogen K, Pressney I, Coutroubis D and Miles K. Tumour heterogeneity in oesophageal cancer assessed by CT texture analysis: preliminary evidence of an association with tumour metabolism, stage, and survival. Clinical radiology. 2012; 67: 157-64.

22. Ganeshan B, Goh V, Mandeville HC, Ng QS, Hoskin PJ and Miles KA. Non-small cell lung cancer: histopathologic correlates for texture parameters at CT. Radiology. 2013; 266: 326-36.

23. Ng F, Ganeshan B, Kozarski R, Miles KA and Goh V. Assessment of primary colorectal cancer heterogeneity by using whole-tumor texture analysis: contrast-enhanced CT texture as a biomarker of 5-year survival. Radiology. 2013; 266: 177-84.

24. Ganeshan B, Miles KA, Young RG and Chatwin GR. Hepatic enhancement in colorectal cancer: texture analysis correlates with hepatic hemodynamics and patient survival. Academic radiology. 2007; 14: 1520-30.

25. Ganeshan B, Miles KA, Young RC and Chatwin CR. In search of biologic correlates for liver texture on portal-phase CT. Academic radiology. 2007; 14: 1058-68.

26. Ganeshan B, Miles KA, Young RC and Chatwin CR. Hepatic entropy and uniformity: additional parameters that can potentially increase the effectiveness of contrast enhancement during abdominal CT. Clinical radiology. 2007; 62: 761-8.

27. Ganeshan B, Miles KA, Young RG and Chatwin CR. Texture analysis in non-contrast enhanced CT: impact of malignancy on texture in apparently disease-free areas of the liver. European journal of radiology. 2009; 70: 101-10. 


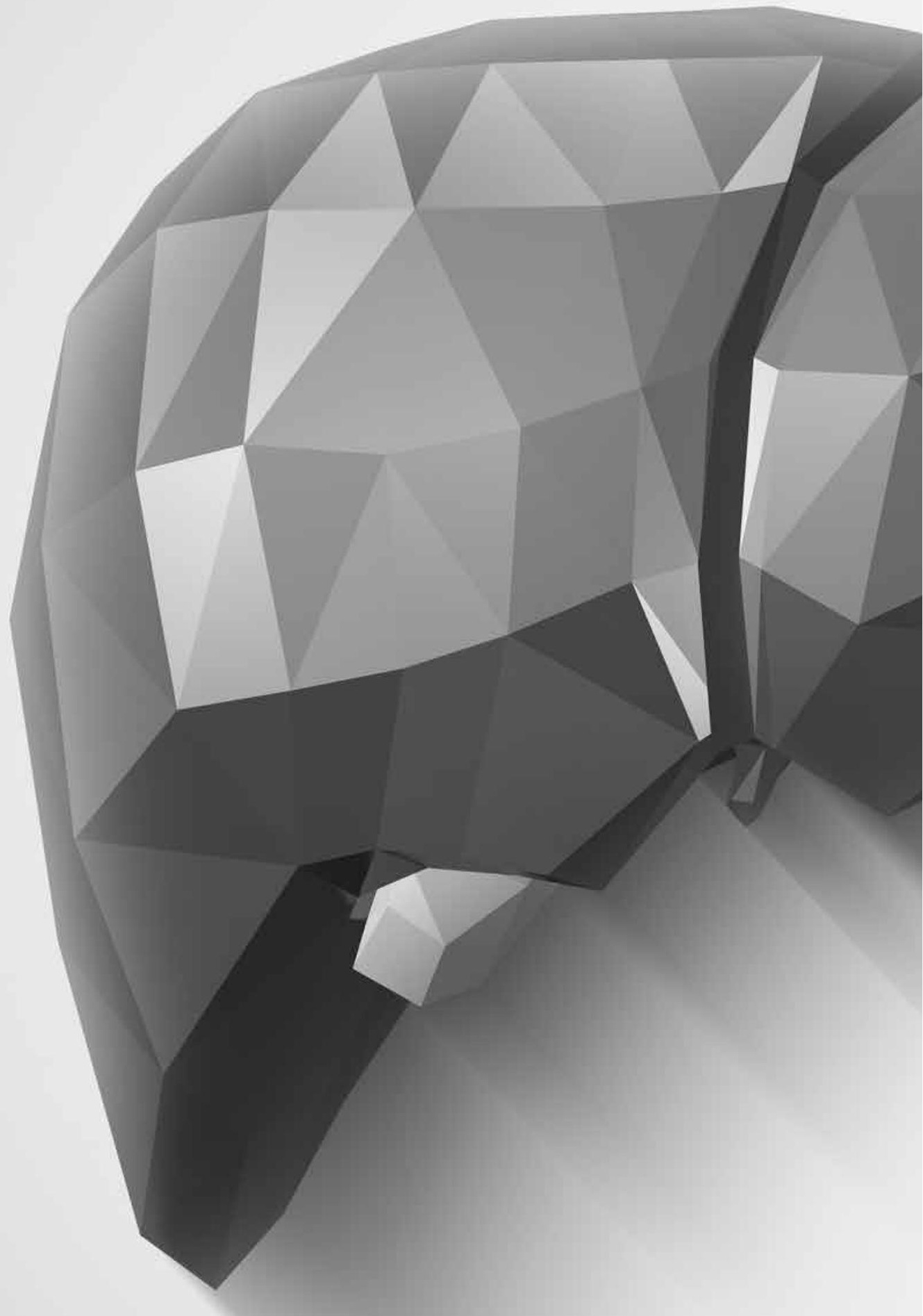





\section{Abstract}

\section{Background}

The assessment of colorectal liver metastases (CRLM) after treatment with chemotherapy is challenging due to morphological/functional without changes in size. The aim of this review was to assess the value of FDG-PET, FDG-PET-CT, CT and MRI in predicting response to chemotherapy in CRLM.

\section{Methods}

A systematic review was undertaken based on PRISMA statement. PubMed and Embase were searched up to October 2016 for studies on the accuracy of PET, PET-CT, CT and MRI in predicting RECIST or metabolic response to chemotherapy and/or survival in patients with CRLM. Articles evaluating the assessment of response after chemotherapy were excluded.

\section{Results}

Sixteen studies met inclusion criteria and were included for further analysis. Study results were available for 6 studies for FDG-PET(-CT), 6 studies for GT and 9 studies for MRI. Generally, features predicting RECIST or metabolic response often predicted shorter survival. The ADC (apparent diffusion coefficient, on MRI) seems to be the most promising predictor of response and survival. In CT-related studies, few attenuation-related parameters and texture features show promising results. In FDG-PET(-CT), findings were ambiguous.

\footnotetext{
Discussion

Radiological data on the prediction of response to chemotherapy for CRLM is relatively sparse and heterogeneous. Despite that, a promising parameter might be ADC. Second, there seems to be a seemingly counterintuitive correlation between parameters that predict a good response and also predict poor survival.
} 


\section{Introduction}

Approximately $15-25 \%$ of patients with colorectal cancer will present with synchronous metastases, with the liver as the predominant site ${ }^{1,2}$. Patients with potentially resectable synchronous colorectal liver metastases (CRLM) usually receive neoadjuvant chemotherapy in order to achieve shrinkage of the liver metastases, which increases the chance of a curative resection ${ }^{3}$. Response assessment after chemotherapy is mainly done using cross-sectional imaging and is used to help determine whether the response is sufficient to treat a patient with curative intent ${ }^{4}$. The most commonly used system for the assessment of response after neoadjuvant chemotherapy is Response Evaluation Criteria In Solid Tumours (RECIST) $^{5}$. RECIST is based on size measurements, which are known to have limitations. For example, as a result of successful treatment, metastatic lesions can undergo necrotic changes without a notable reduction in lesion size ${ }^{6,7}$. In such cases, RECIST will fail to recognise a treatment response. Moreover, chemotherapy can affect the liver parenchyma in such a way that it impairs the assessment of lesions. Diffuse fatty changes may conceal metastases on CT, while focal steatosis may mimic tumour ${ }^{8,9}$. To overcome these issues, it has been suggested to explore imaging techniques that are capable of predicting the response before the onset of chemotherapy instead of assessing it after treatment has been completed. An additional benefit of such an approach is that it may create opportunities to adapt and optimise the neoadjuvant treatment based on the anticipated treatment response. Several imaging studies have addressed the topic of pre-treatment response prediction in patients with CRLM, using PET, CT and MRI as data sources. More advanced (functional) imaging and image post-processing techniques such as diffusion weighted imaging (DWI) and dynamic contrast-enhanced (DCE) MRI or texture analyses are currently being explored ${ }^{10,11}$. So far, there is no clear consensus on which imaging modality is the most promising technique. Therefore, the objective of the present study was to perform a systematic review in order to identify the most promising imaging technique for predicting the response to chemotherapy in patients with CRLM with the aim of identifying areas for future research.

\section{Methods and materials}

PubMed, MEDLINE and Embase were searched from January 1985 to October 2016 using the following free search terms: 'colorectal neoplasms or carcinoma or 
cancer', 'neoplasm metastasis or hepatic or liver metastases', 'chemotherapy, adjuvant', 'positron emission tomography' or 'PET', 'magnetic resonance imaging' or 'MRI', 'computed tomography' or 'CT' and 'PET-CT' or 'PET/CT'. Also, Mesh terms were used for the search ('Colorectal Neoplasms', 'Neoplasm Metastasis', 'Chemotherapy, Adjuvant', 'Positron-Emission Tomography', 'Magnetic Resonance Imaging' and 'Computed Tomography'. No language restriction was used. Studies were included when they met the following criteria: (1) inclusion of patients with CRLM, (2) systemic chemotherapy in a non-experimental regime (capecitabine, 5-fluorouracil combined with leucovorin, oxaliplatin, irinotecan and/or bevacizumab) $)^{3}$, (3) PET-CT, MRI or CT before the start of chemotherapy (4) outcome consisting of either histology, RECIST, progression-free survival (PFS)/time to progression (TTP) or overall survival (OS) as a reference standard. Case reports, reviews, articles that evaluated detection of CRLM and studies that evaluated response after chemotherapy were excluded.

Two reviewers (RB \& MM) independently searched for eligible studies. Titles and abstracts were checked in order to select studies, which potentially met the inclusion criteria. Full-text copies of the selected studies were independently reviewed by both reviewers to evaluate which studies met the inclusion criteria. In case of disagreement consensus was reached. References were checked for additional eligible studies. Data that were extracted from the studies were: (1) number, gender and age of patients, (2) study objective, (3) type of reference standard, (4) duration of follow-up, (5) parameter of analysis (e.g. maximum diameter of a lesion) and (6) unit of analysis (lesion or patient-based analysis). Study quality was assessed with the QUADAS-2 checklist ${ }^{12}$. Results are reported according to the PRISMA statement ${ }^{13}$.

\section{Results}

\section{Literature Search}

The search yielded 208 studies of which 16 met inclusion criteria for further analysis, Figure 1 shows the study selection procedure in a PRISMA flowchart. 45 studies were selected based on titles and abstracts. Of these 45 articles, 29 were excluded $^{14-42}$, leaving 16 articles for inclusion ${ }^{10,11,43-56}$. More information on the excluded articles and the reason for exclusion is available in the supplementary data. 
Of the included studies, $12 / 16$ studies had a low risk of selection bias ${ }^{10,11,44,45,47,48,50-}$ 52,54-56. Selection bias was introduced in four studies due to unclear enrolment or inappropriate exclusions ${ }^{11,43,46,53}$. The most encountered quality issue concerned the reference standard (RECIST) and its blinding ${ }^{10,11,43-46,49,50,52,55,56}$. There were no concerns regarding index test and reference standard applicability. Results of the quality assessment with the QUADAS-2 checklist are available as supplementary data. Based on the overall quality of the studies, none of them was excluded.

Of the 16 articles included, 11 studied a single modality ${ }^{10,43,45,46,48-52,54,55}$ and 5 studies compared two modalities ${ }^{11,44,47,53,56}$. In total, 5 articles studied FDGPET $^{11,44,50,53,56}, 1$ article studied the FDG-PET-CT ${ }^{47}, 6$ articles studied CT ${ }^{43,45-47,51,53}$ and 9 articles studied MRI ${ }^{10,11,44,48,49,52,54-56}$. The number of patients ranged from 10 to 145 patients per study, with a total of 560 patients evaluated in all studies. The percentage of male patients varied from $54-80 \%$. The reference standards/ outcome measures were as follows: 11 studies used RECIST $(1.1)^{10,11,43,46-50,52,53,55}$, 5 studies used PFS, TTP and OS ${ }^{44,45,50,54,56}$ and only one study used histology after surgery (tumour regression grade, TRG) ${ }^{51}$. Individual study characteristics are presented in the supplementary data. 


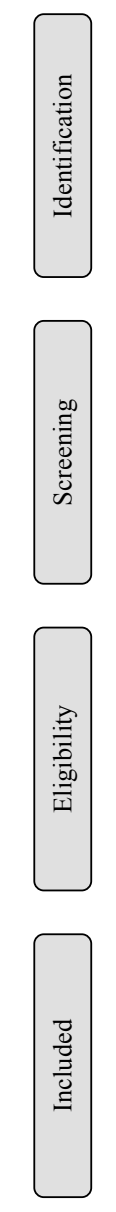

$$
\begin{gathered}
\text { Records identified through database } \\
\text { searching } \\
(\mathrm{n}=189)
\end{gathered}
$$

Additional records identified through other sources $(\mathrm{n}=29)$
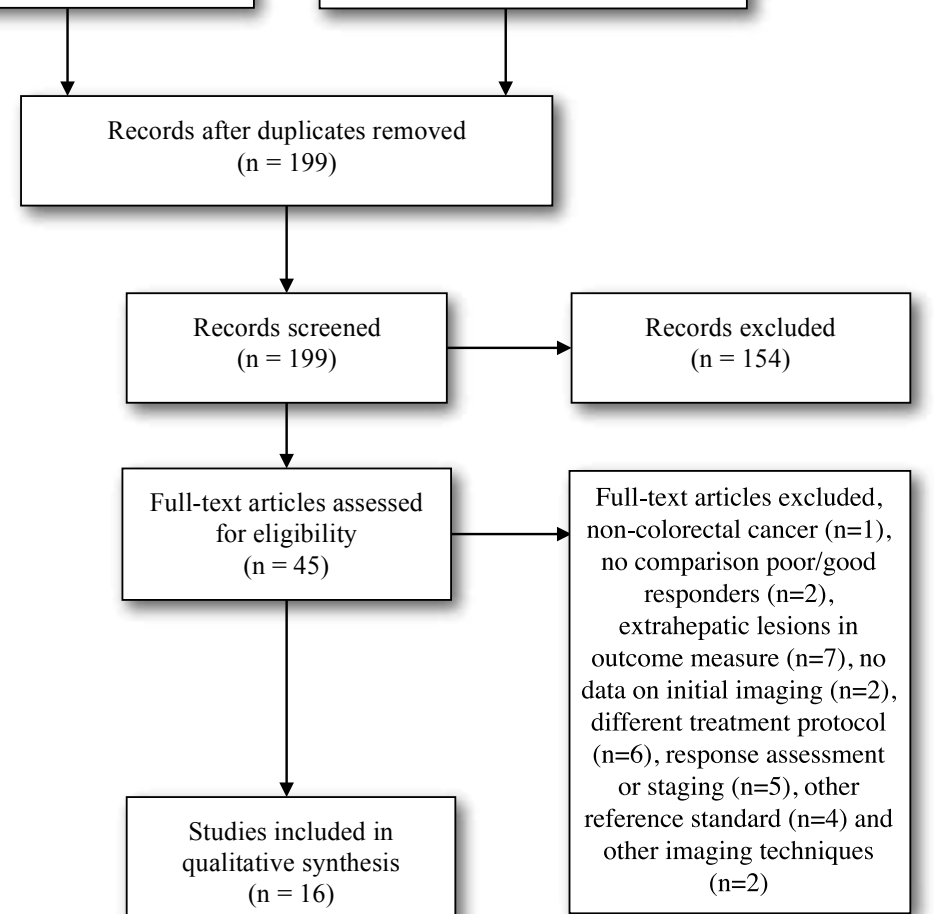

\section{Figure 1. PRISMA flow chart}

\section{FDG-PET studies}

Table 1 provides the most important results from the studies on PET. The main input variables were $\mathrm{SUV}_{\max }$ (maximum standardised uptake value), $\mathrm{SUV}_{\text {mean }}$ (mean standardised uptake value), $\mathrm{MR}_{\mathrm{glc}}$ (glucose metabolic rates), TLG (total lesion glycolysis) and MTV (metabolic tumour volume). Several reports showed that $\mathrm{SUV}_{\max }$ before treatment is significantly lower in patients with a favourable outcome, including RECIST responders ${ }^{11,50}$, and patients with longer $\mathrm{OS}^{44}$. However, other studies found no correlation between $\mathrm{SUV}_{\text {max }}$ (or $\mathrm{SUV}_{\text {mean }}$ ) and $\mathrm{OS}^{47,53}$ or PFS ${ }^{44,47,50}$. Kim et al. even found contradictory results with higher SU$\mathrm{V}_{\text {mean }}$ value in responders ${ }^{47}$. According to Vriens et al. a lower $\mathrm{MR}_{\text {glc }}$ resulted in a better OS and $\operatorname{PFS}(P=0.002-0.005)^{56}$. A higher TLG resulted in a lower OS $(P=0.01)$ but had no influence on the $\mathrm{PFS}^{44}$. 


\section{CT studies}

Table 1 shows the most important results from the studies on CT. A wide range of parameters was tested, including perfusion-related parameters (blood flow, blood volume, portal/arterial liver perfusion, $\mathrm{AEF}$ (arterial enhancement fraction)), size and volume metrics (maximum diameter, measured in one, two or three planes, tumour to liver ratios or tumour volume), attenuation parameters (maximum, mean or minimum Hounsfield units (HU)) and texture features (e.g. entropy, uniformity, skewness). Joo et al. reported a lower AEF measured in the tumour in responders $(P=0.005)^{46}$, reflecting hypervascular lesions. A higher minimum HU of the three largest lesions leads to a longer OS $(P=0.02)$ without any influence on $\mathrm{TTP}^{45}$. According to Ahn et al. higher mean HU in the tumour was independently associated with response to chemotherapy $(P=0.017)^{43}$, while Huellner et al. found no significant difference in PFS or OS $(P=0.13-0.81)^{45}$. Skewness (measured in 2D texture analysis) was significantly lower in responders $(P=0.025)^{43}$. All other perfusion-, metric- or attenuation related parameters and textural features were not significantly different between responders and non-responders ${ }^{34,47,51,53}$.

\section{MRI studies}

Table 1 shows the most important results from the studies on MRI. Various sequences and techniques were evaluated, with three studies focusing on ADC (apparent diffusion coefficient; the quantification of diffusion in a lesion or area, where a lower $\mathrm{ADC}$ reflects more dense tissue, corresponding to tumour ${ }^{57}$ ) related parameters, others focusing on DCE-MRI (dynamic contrast-enhanced MRI in which the inflow and outflow of contrast is assessed) related parameters, such as $\mathrm{k}_{\mathrm{ep}}$ (rate constant of Gd-DTPA uptake), $\mathrm{k}^{\text {trans }}$ (transfer constant), $\mathrm{v}_{\mathrm{e}}$ (extravascular extracellular space per unit volume of tissue), and the remaining studies focusing on HPI (hepatic perfusion index), T2* MRI (susceptibility-weighted MRI) or T2 relaxation times. Two studies described a significantly lower ADC in responders $(P=0.000-0.002)^{48,49}$. In contrast, Heijmen et al. described that a lower ADC value was associated with a worse outcome in terms of shorter PFS and $\mathrm{OS}^{44}$. ADC skewness, kurtosis and variance were not associated with response to chemotherapy $(P=0.21-0.85)^{49}$. Coenegrachts et al. stated that $\mathrm{k}_{\mathrm{ep}}$ was lower in responders, when measured on the slice level through the largest diameter of the target lesion $(P<0.001)^{10}$. Other studies did not confirm this and reported no difference in $\mathrm{k}_{\mathrm{ep}}$ between responders and non-responders and no association with PFS or OS ${ }^{55,56}$. $\mathrm{K}_{\text {trans }}, \mathrm{v}_{\mathrm{e}}$ and HPI were not predictive of response to chemotherapy and were not related to PFS or $\mathrm{OS}^{11,54-56}$. A smaller maximum axial diameter, measured on T2, 
indicated a better PFS and OS $(P=0.032-0.039)^{56}$. A higher T2* lead to a shorter OS, but was not related to PFS $(P=0.01)^{44}$. T2 relaxation time was not significantly different between responders and non-responders $(P=0.83)^{52}$.

Data and details on FDG-PET(-CT), GT and MRI from all the included studies are provided in supplementary tables. 


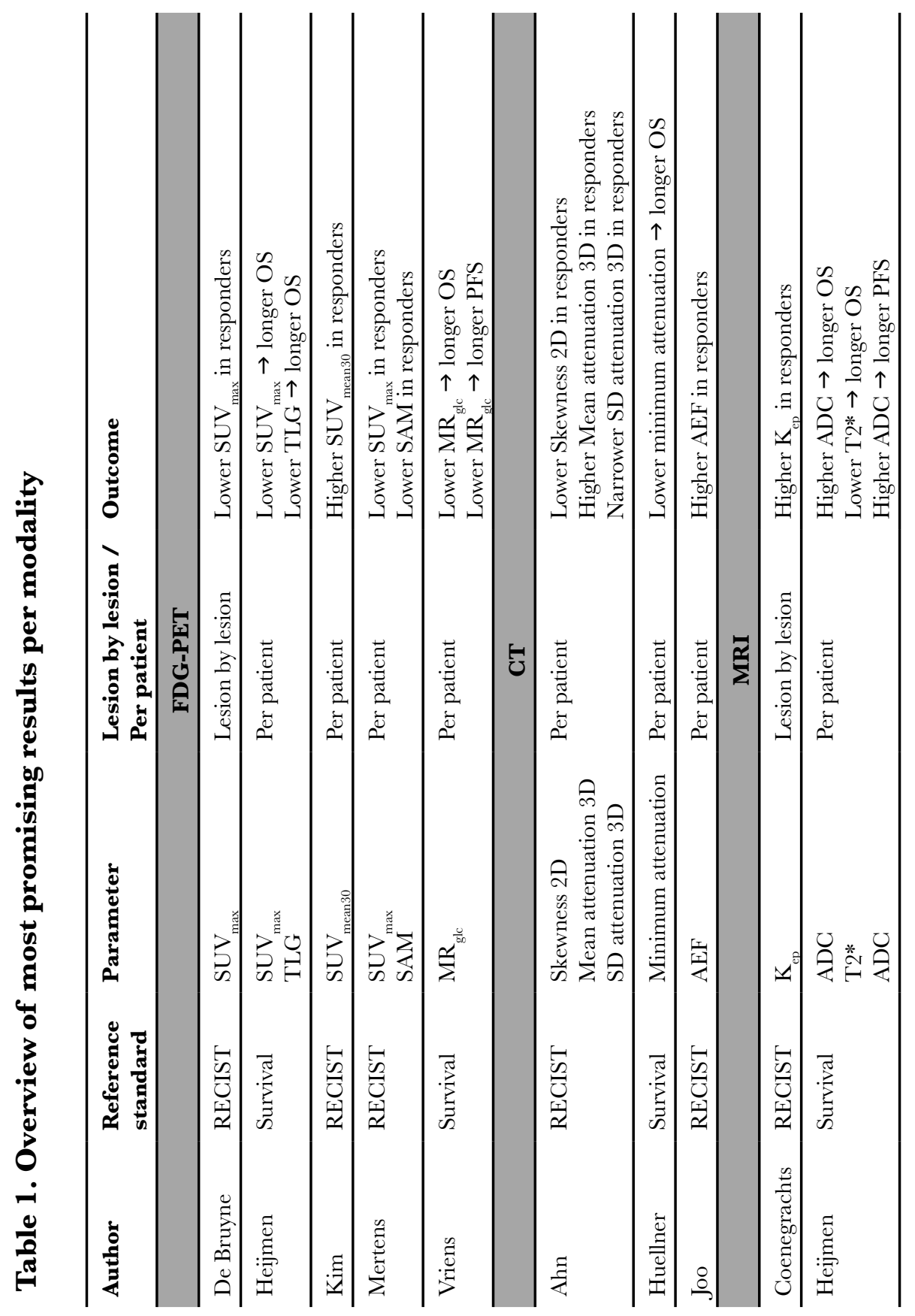




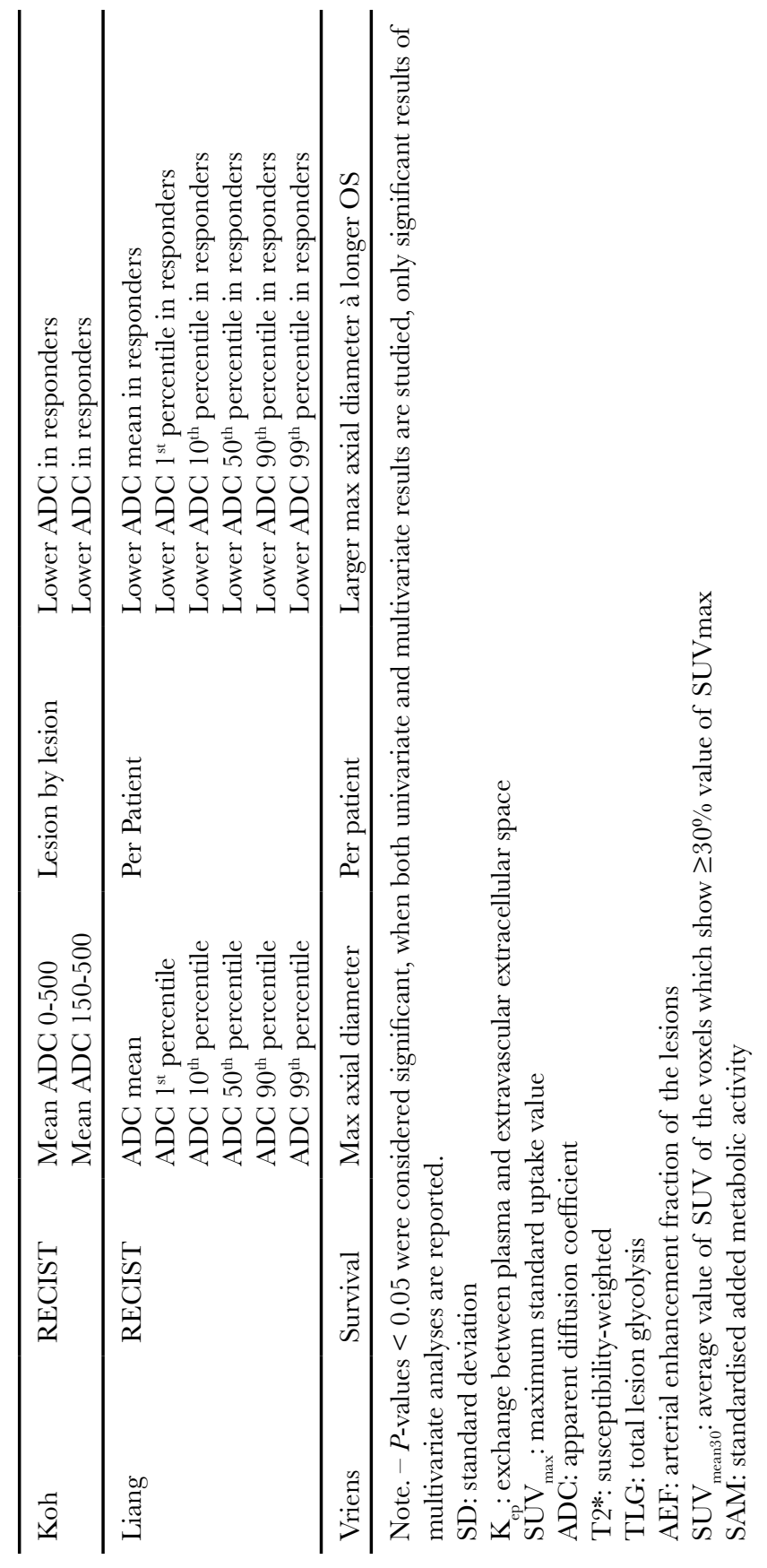




\section{Discussion}

The aim of this systematic review was to explore which imaging techniques may be of value for the pre-treatment prediction of response to chemotherapy in CRLM. The literature on this topic is rather heterogeneous with regard to outcome and techniques used per modality. Therefore, the results should be interpreted with care. Most studies focus on advanced imaging techniques. The ADC derived from diffusion weighted imaging in MRI seems to be the most promising predictor of response and survival. For CT, most results are disappointing; only a few attenuation-related parameters and texture features show promising results. These results are mostly described in one single study, which makes them less robust than the data on ADC. In FDG-PET, the findings were ambiguous. Some reports showed that $\mathrm{SUV}_{\text {max }}$ before treatment is significantly lower in patients with a favourable outcome, while other studies found no correlation or even a contradictory correlation.

Despite the heterogeneity in techniques and outcome parameters, there was an unexpected counterintuitive finding that parameters that predict a good response to chemotherapy (in terms of RECIST) also seem to be predictive of a worse prognosis. For example, in CT, a higher attenuation was associated with a better response, but a shorter survival ${ }^{43,45}$. Similarly, in MRI, ADC was lower in responders while it was higher in patients with a longer $\mathrm{OS}^{48,49}$. One possible explanation for this phenomenon might be related to angiogenesis and tumour vascularization. Angiogenesis is a key cancer hallmark involved in tumour growth and metastasis that leads to the formation of new blood vessels ${ }^{58,59}$. As a general rule, patients with highly vascular tumours have a beneficial outcome when treated with radiotherapy or chemotherapy ${ }^{60}$, as these tumours exhibit an oxygen-rich environment, which makes them more sensitive to therapy ${ }^{58,60,61}$. Although highly vascular tumours usually respond better, they are also more aggressive, leading to faster tumour growth and a higher propensity to metastasize ${ }^{60}$, which might explain the poorer survival in these patients. In other malignancies, such as nonsmall cell lung carcinoma (NSCLG) and cervical cancer, similar contradictory findings have been described ${ }^{62-66}$. Contrary to the findings for MRI and CT, for FDG-PET the relation between a good response and poor survival was not clearly found. Tumours with a high glucose metabolism are likely to have a higher vascularization to supply sufficient glucose for growth ${ }^{67}$. This would be expected to lead to a good response and poor survival, if the abovementioned hypothesis is followed. Two studies indeed reported lower glucose metabolism to be associated 
with longer survival ${ }^{44,56}$. However, the reported results regarding the association between glucose metabolism and response were conflicting: Kim et al. found a higher $\mathrm{SUV}_{\text {mean }}$ in responders ${ }^{47}$, but Mertens et al. reported a lower baseline $\mathrm{SUV}_{\max }$ in patients that showed a good response ${ }^{11,50}$. As suggested by the authors, this difference in the ability to predict response might be explained by the use of bevacizumab in their treatment regimen ${ }^{50}$, which does improves survival ${ }^{68}$, but does not lead to an increase in RECIST-defined response.

Another explanation for the counterintuitive finding that a good response is correlated with a poorer survival could be the definition of response in radiological studies. Most studies use RECIST as the reference standard, which limits the quality of studies on CRLM in general, as RECIST is a suboptimal reference standard due to the use of size as a response parameter. Up until now, only one study has been conducted to determine the accuracy of RECIST in the assessment of CRLM, which has been conducted before the wide introduction of targeted therapies ${ }^{69}$. In the era of targeted therapies, evaluation based on tumour size alone might no longer be the best option for response assessment because of necrosis and cavitation ${ }^{5}$. Another study showed that neither RECIST nor mRECIST is able to assess the amount of residual viable burden in $\mathrm{CRLM}^{70}$. This could imply that the use of RECIST as an indication for long-term outcome, is not reliable, which could explain the counterintuitive finding in our study. Despite these critics, there is yet no other reliable method of response assessment that can replace histopathology ${ }^{71}$. In the specific case of CRLM, histopathology is often unavailable, as many patients will not undergo a surgical resection. Alternative endpoints have been proposed. Prolongation of OS is generally the most relevant measure of clinical response in oncological research ${ }^{72,73}$. The fact that the current review showed that factors predicting a good response seem to be associated with poor survival, supports the advice against using alternative endpoints in clinical research with targeted therapies and stress the need for a reliable non-invasive tool to assess response other than RECIST.

There are some limitations to this study. The main limitation is that studies are heterogeneous with regard to the study population, scan protocols, types of chemotherapy and the use of targeted therapy. This made it impossible to conduct a meta-analysis. Second, as described above, the lack of histopathology as a reference standard reduces study quality significantly. However, it is difficult to overcome this issue as this is a problem in almost all studies focusing on imaging (and treatment) of CRLM. Third, the quality of the studies was assessed by the 
QUADAS-2 guidelines, but subgroup analyses for good quality studies could not be performed due to a small sample size and because the main reason for lower quality was the lack of histopathology as a reference standard. Last, this systematic review aimed at predicting response by imaging, while from a clinical perspective prediction of non-response is very relevant. The results of this systematic review can be used when new studies are designed that focus on prediction of response as well as non-response to therapy.

In conclusion, this systematic review shows that the data on prediction of response to chemotherapy for CRLM are relatively sparse and heterogeneous. Despite that, a promising parameter to predict response to chemotherapy in CRLM before treatment might be ADC. There seems to be a correlation between parameters that predict a good response and also predict poor survival. Although the underlying mechanism is not entirely clear, it might be explained by increased angiogenesis and vascularization which makes tumours more responsive, but also more aggressive. Alternatively, the known limitations of the use of RECIST for response assessment may play a role in this counterintuitive finding. RECIST was mainly used as a reference standard, despite the known limitations of a sizebased response assessment system. Therefore - especially with the increasing use of new targeted chemotherapeutic agents - there is a strong need for studies that use histopathology as a reference standard or the development of an alternative reliable reference standard other than RECIST. 


\section{Supplementary tables}

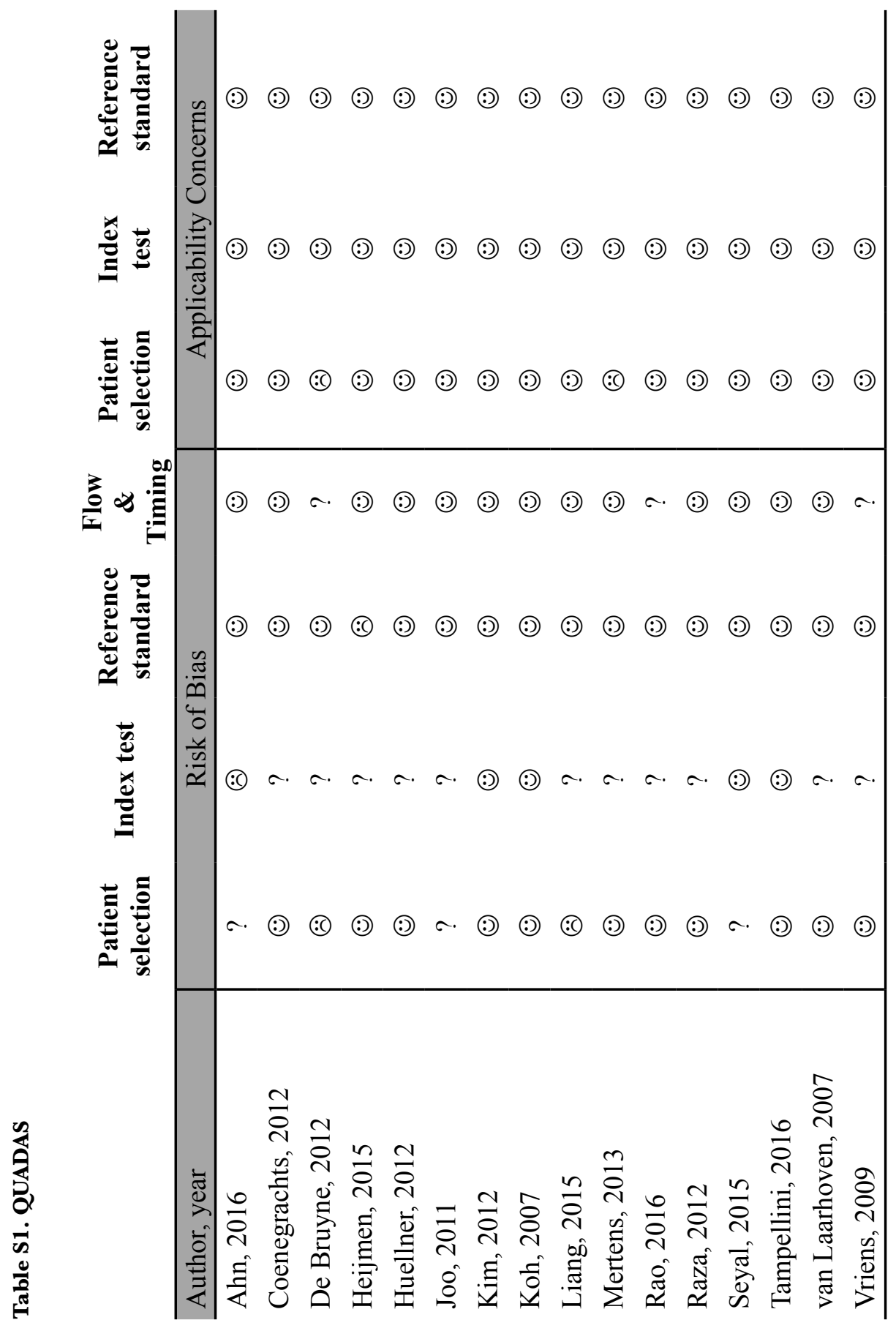




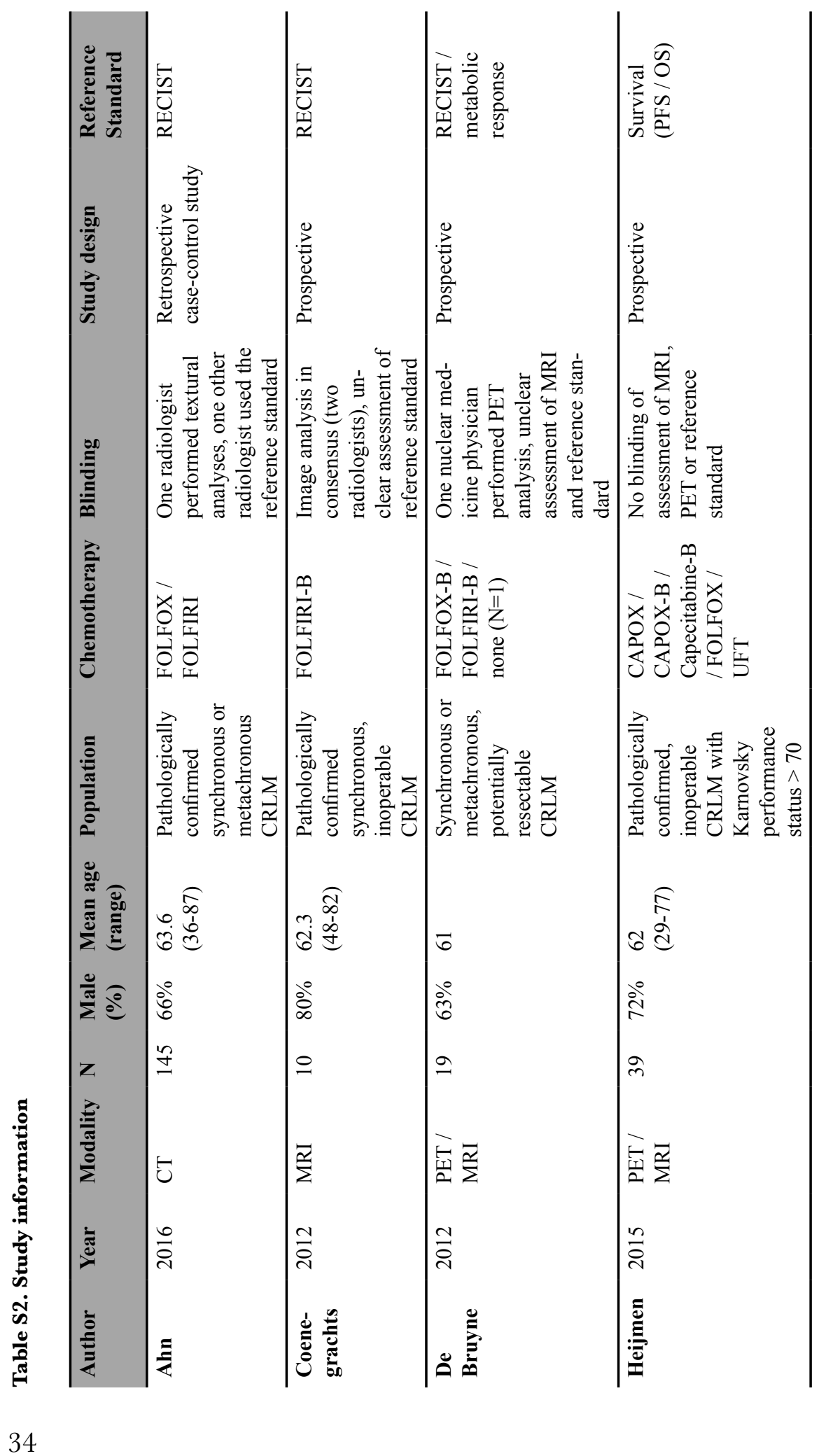




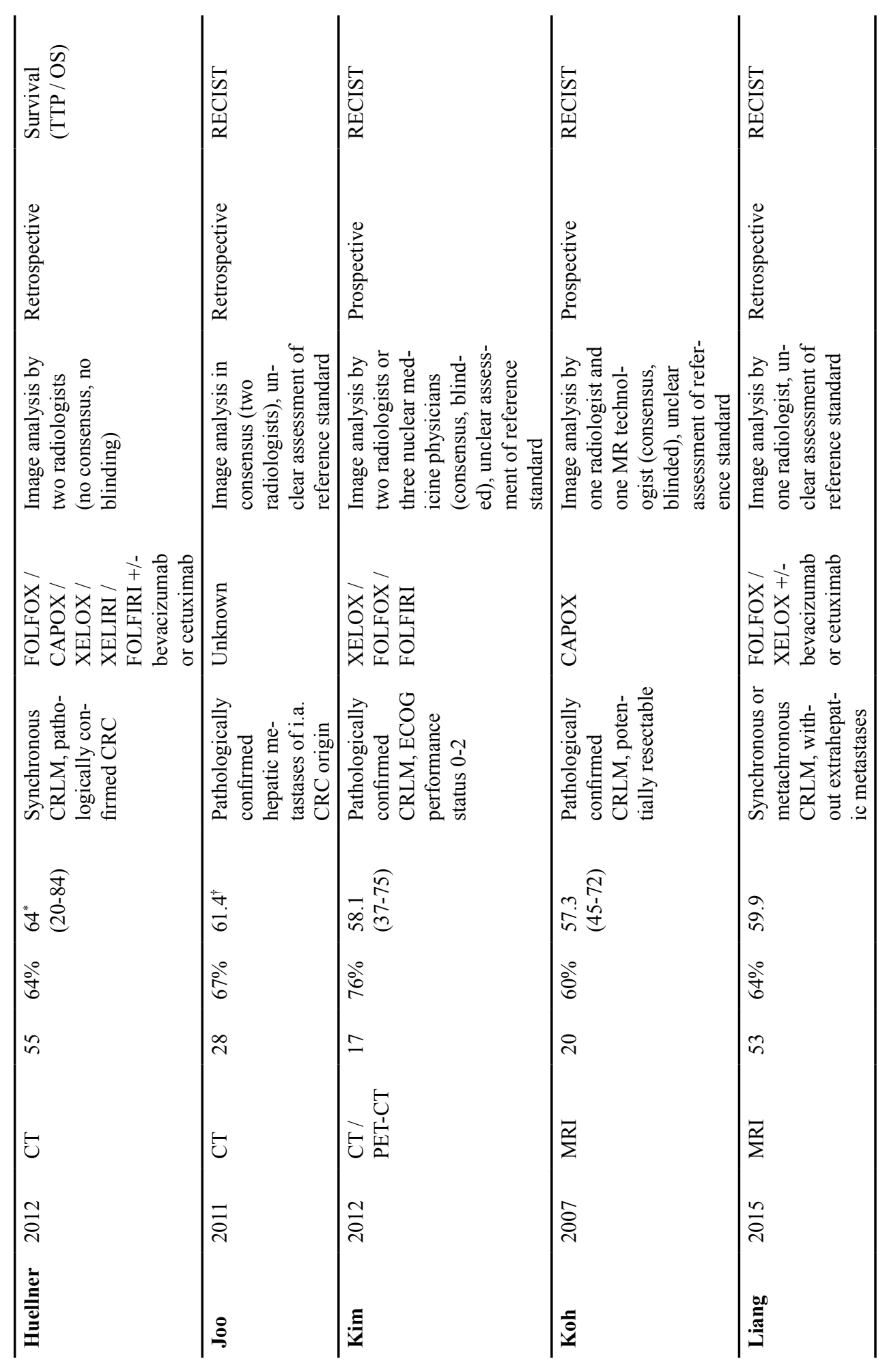




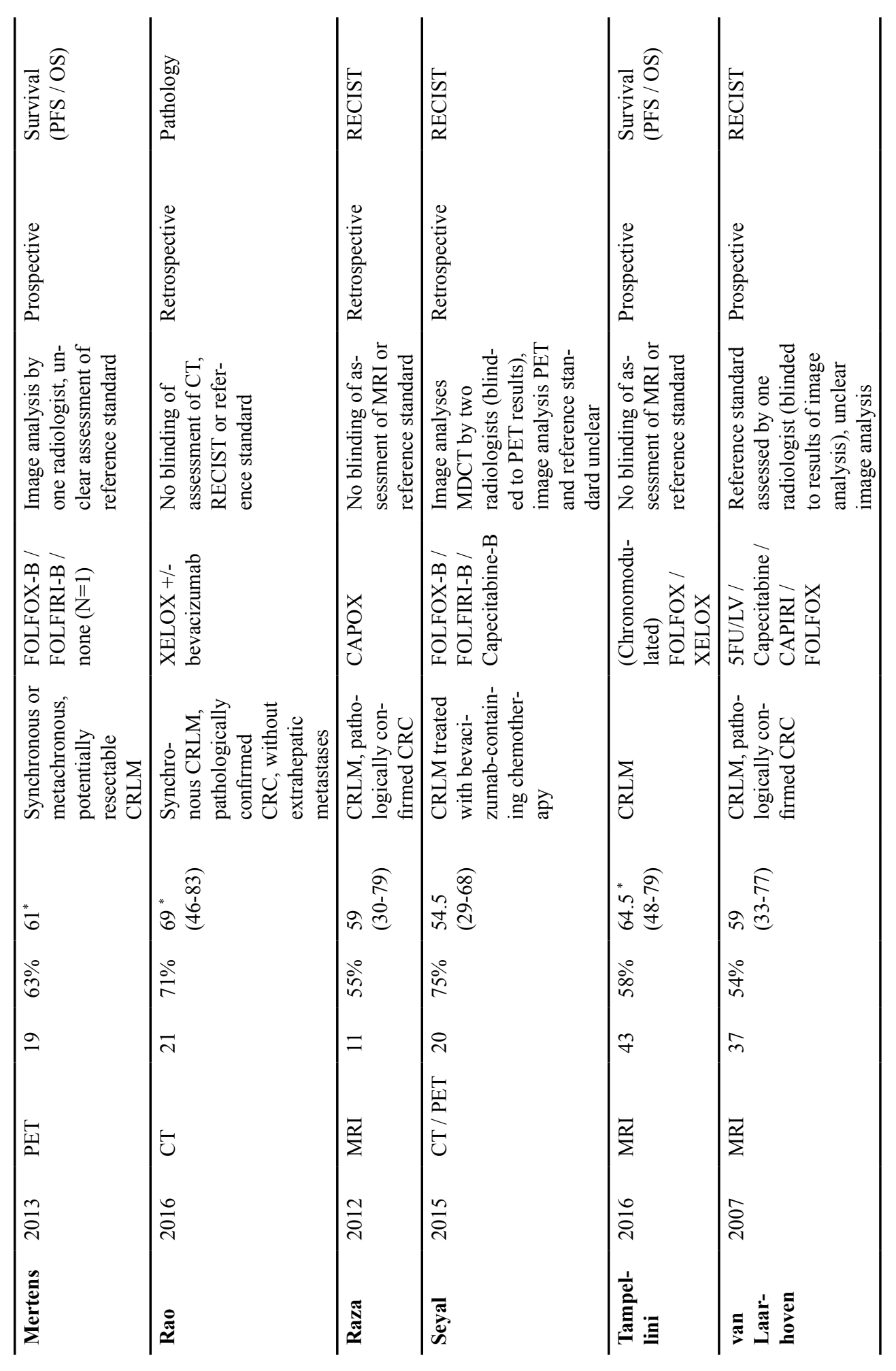




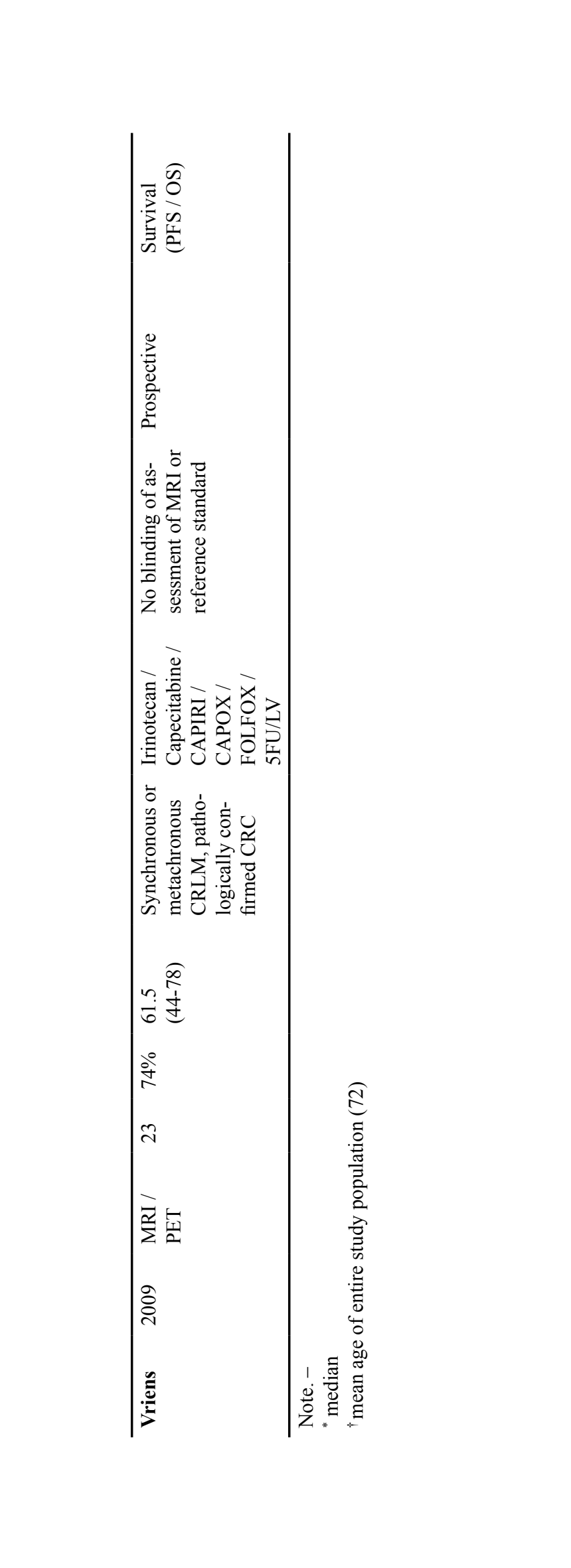




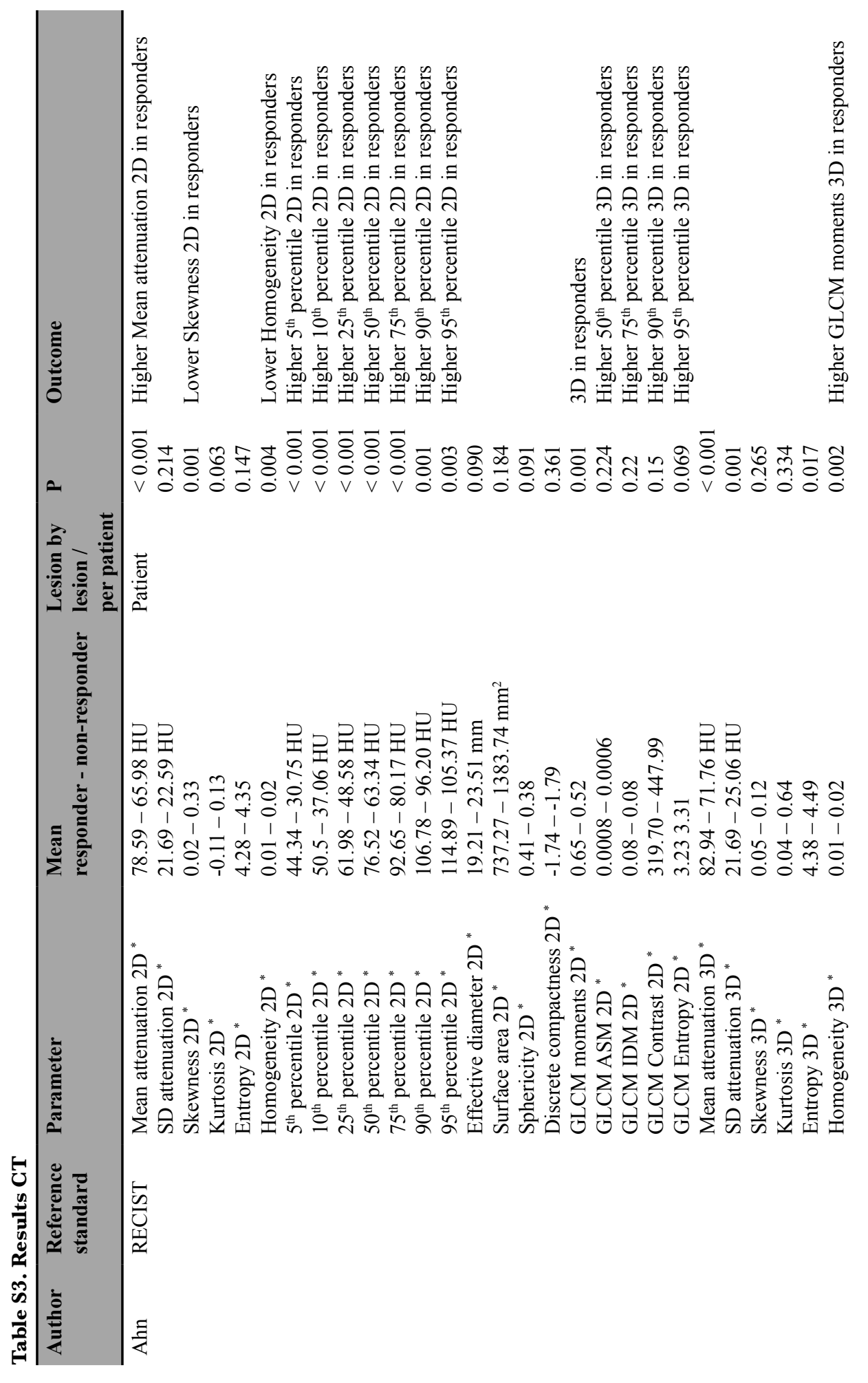




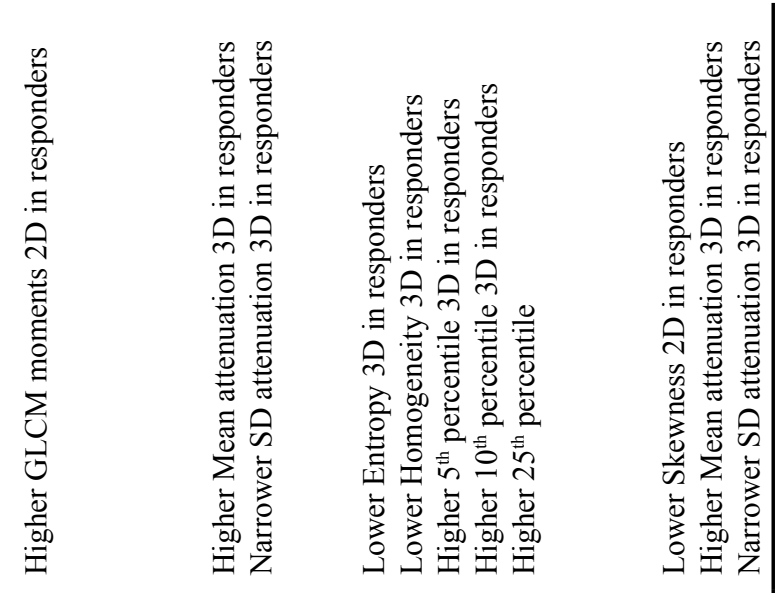

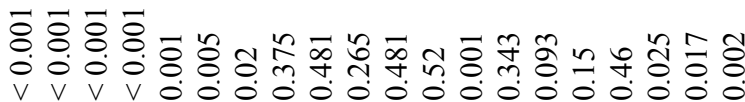

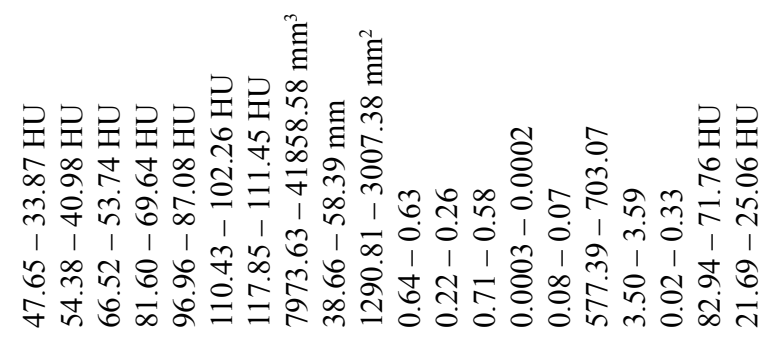

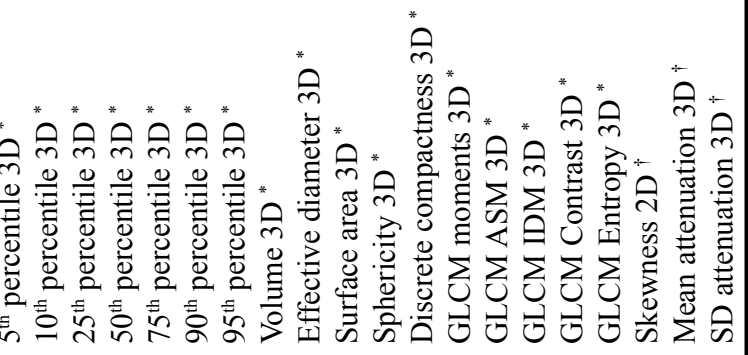




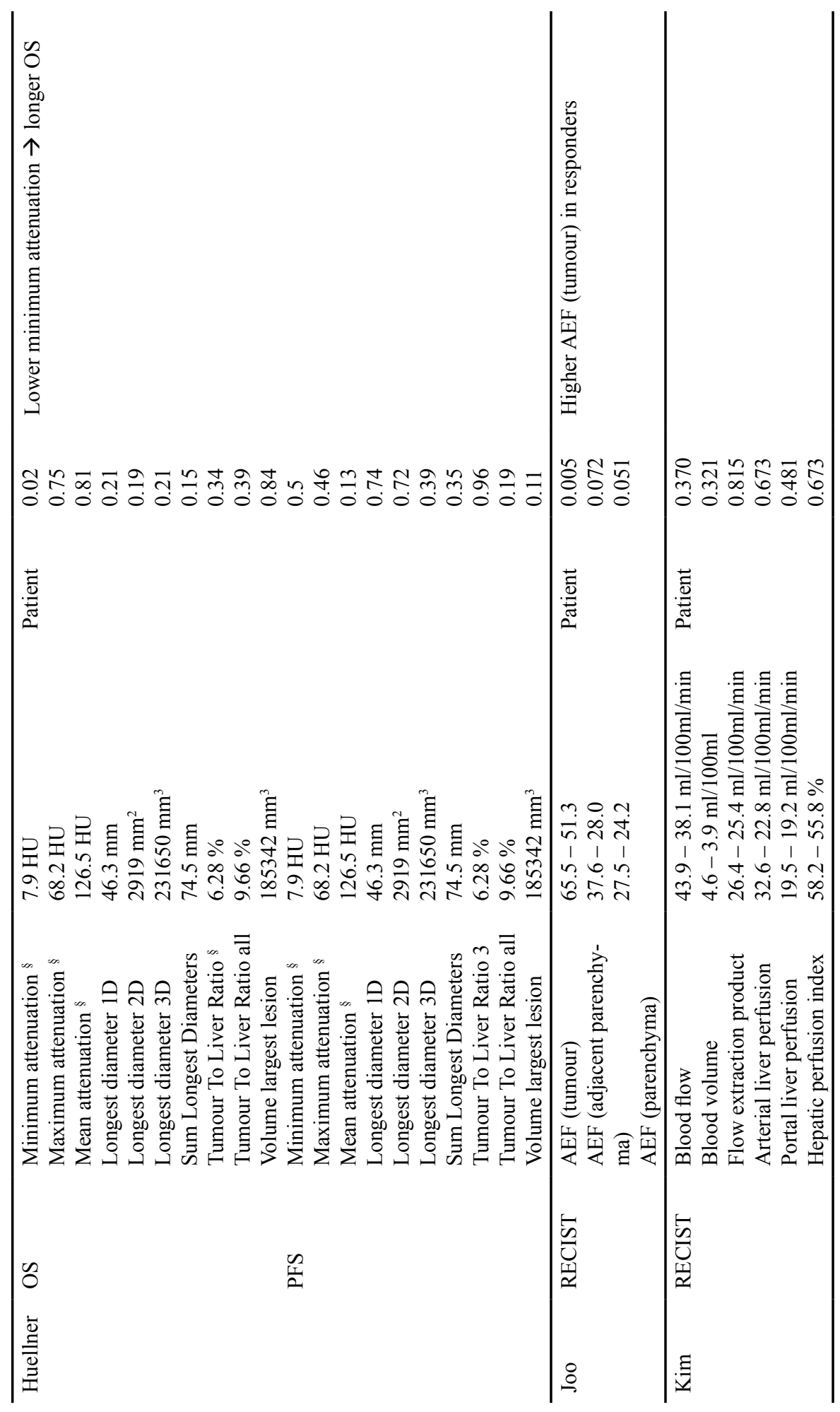




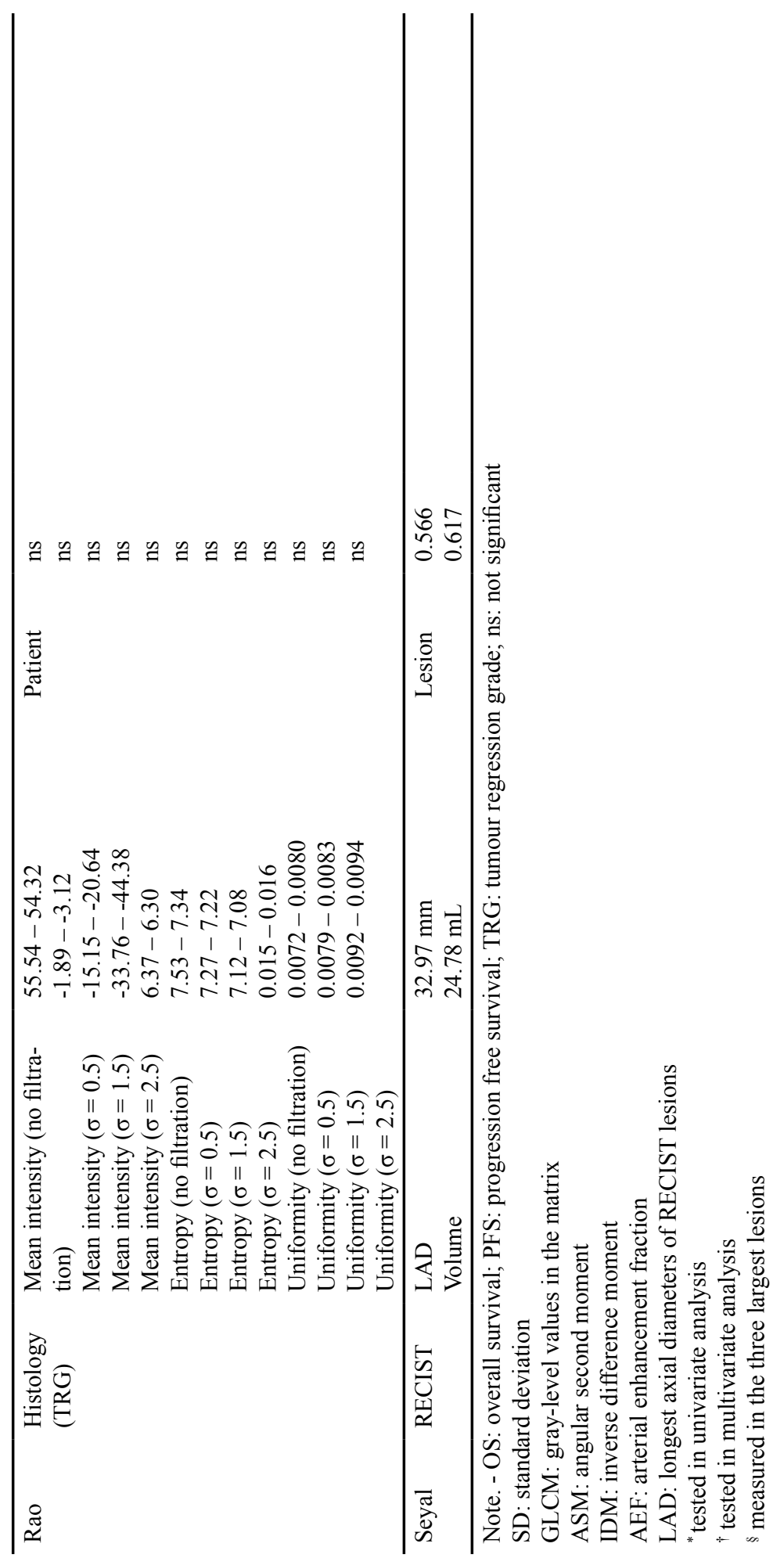




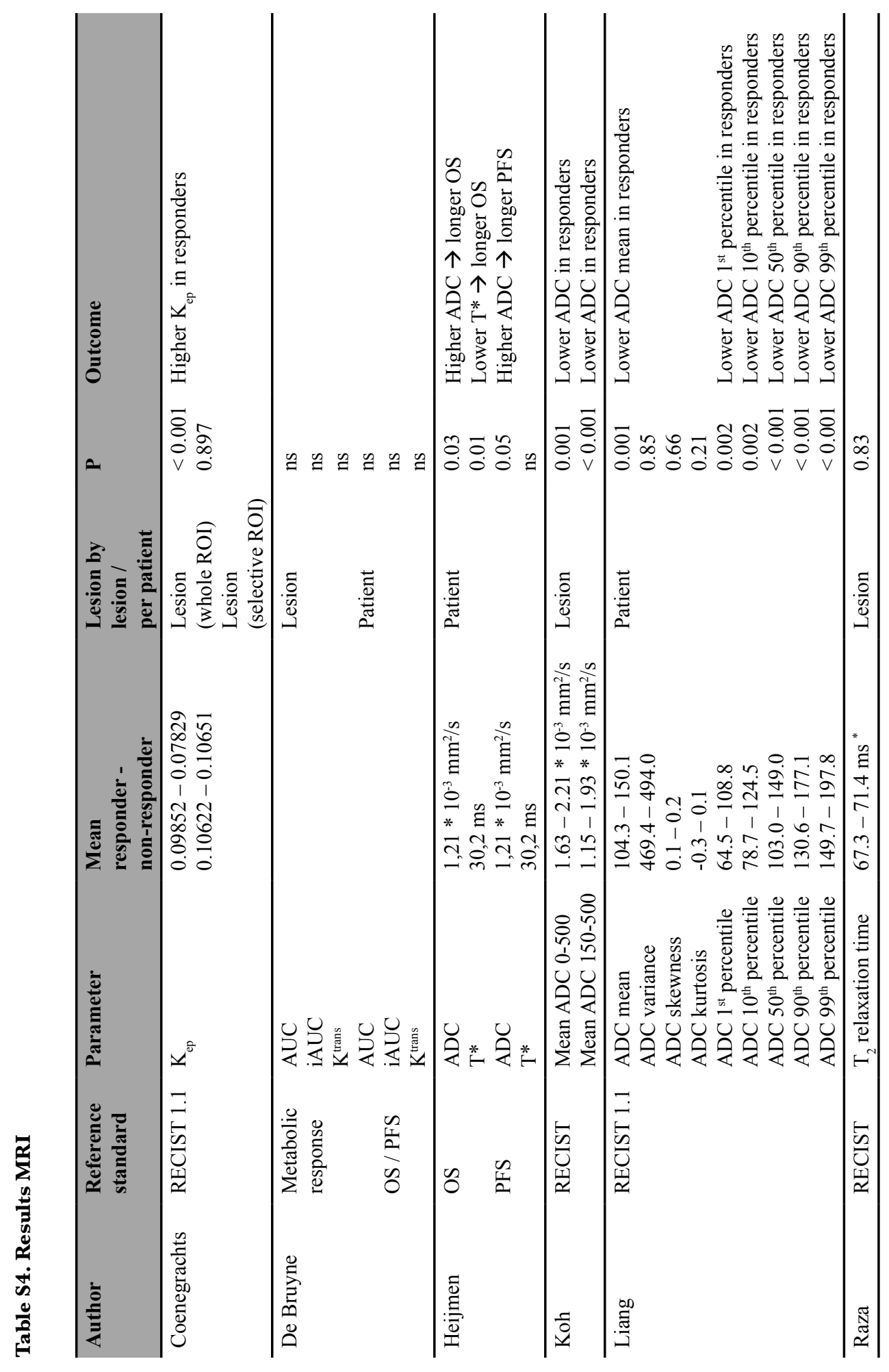




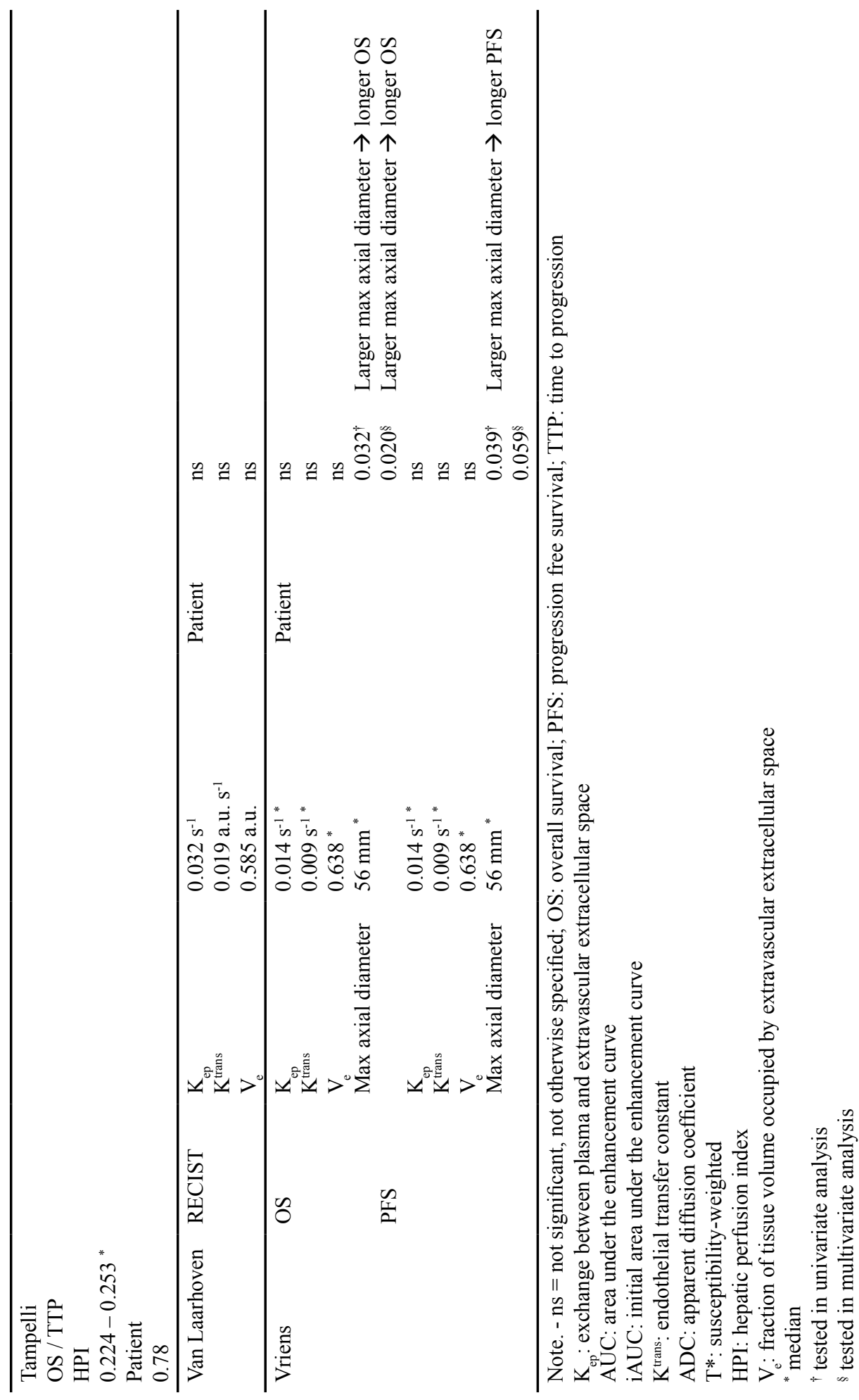




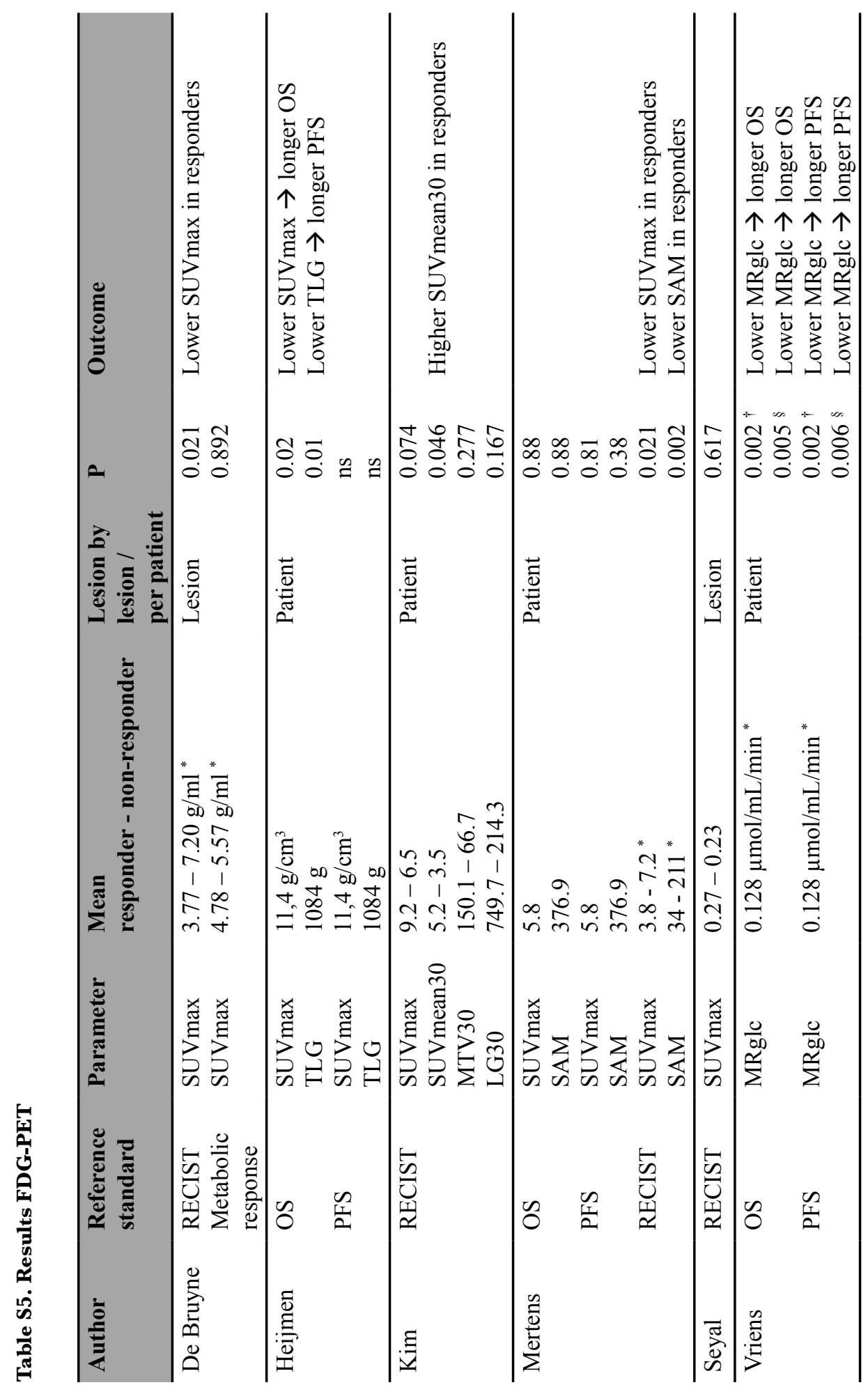




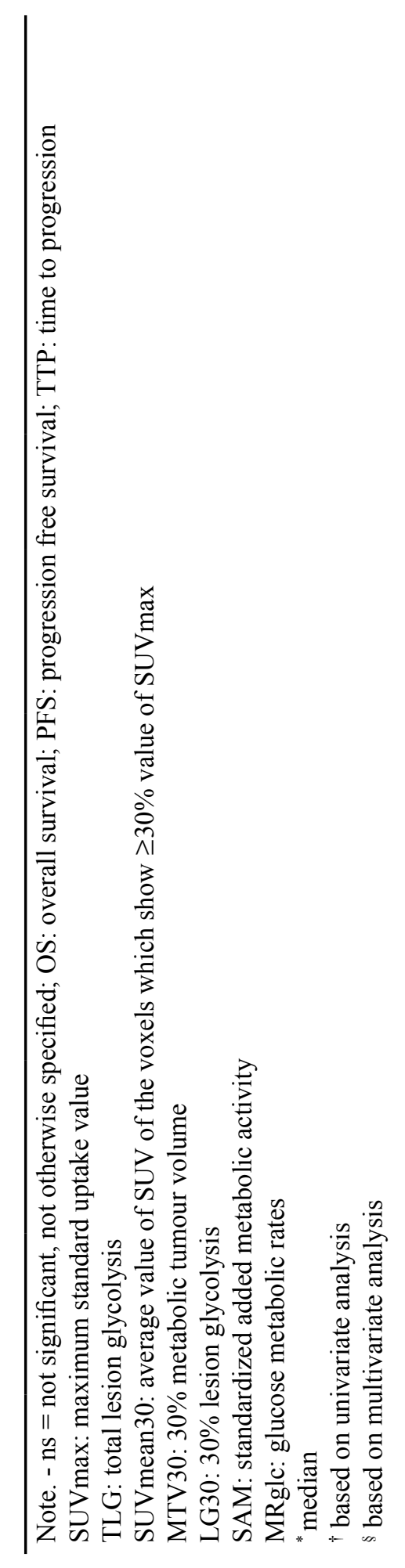




\section{References}

1. Manfredi S, Lepage C, Hatem C, Coatmeur O, Faivre J, Bouvier A-M. Epidemiology and management of liver metastases from colorectal cancer. Annals of surgery 2006; $244(2):$ 254-9.

2. Noren A, Eriksson HG, Olsson LI. Selection for surgery and survival of synchronous colorectal liver metastases; a nationwide study. Eur $\mathcal{F}$ Cancer 2016; 53: 105-14.

3. Van Cutsem E, Cervantes A, Nordlinger B, Arnold D, Group EGW. Metastatic colorectal cancer: ESMO Clinical Practice Guidelines for diagnosis, treatment and follow-up. Ann Oncol 2014; 25 Suppl 3: iiil-9.

4. Bipat S, van Leeuwen MS, Ijzermans JN, Bossuyt PM, Greve JW, Stoker J. Imaging and treatment of patients with colorectal liver metastases in the Netherlands: a survey. The Netherlands journal of medicine 2006; 64(5): 147-51.

5. Desar IM, van Herpen CM, van Laarhoven HW, Barentsz JO, Oyen WJ, van der Graaf WT. Beyond RECIST: molecular and functional imaging techniques for evaluation of response to targeted therapy. Cancer Treat Rev 2009; 35(4): 309-21.

6. Therasse P, Arbuck SG, Eisenhauer EA, et al. New guidelines to evaluate the response to treatment in solid tumors. European Organization for Research and Treatment of Cancer, National Cancer Institute of the United States, National Cancer Institute of Canada. 7 Natl Cancer Inst 2000; 92(3): 205-16.

7. Eisenhauer EA, Therasse P, Bogaerts J, et al. New response evaluation criteria in solid tumours: revised RECIST guideline (version 1.1). Eur 7 Cancer 2009; 45(2): 228-47.

8. Robinson PJ. The effects of cancer chemotherapy on liver imaging. Eur Radiol 2009; 19(7): 1752-62.

9. Pawlik TM, Olino K, Gleisner AL, Torbenson M, Schulick R, Choti MA. Preoperative chemotherapy for colorectal liver metastases: impact on hepatic histology and postoperative outcome. 7 Gastrointest Surg 2007; 11(7): 860-8.

10. Coenegrachts K, Bols A, Haspeslagh M, Rigauts H. Prediction and monitoring of treatment effect using $\mathrm{T} 1$-weighted dynamic contrast-enhanced magnetic resonance imaging in colorectal liver metastases: potential of whole tumour ROI and selective ROI analysis. Eur 7 Radiol 2012; 81 (12): 3870-6.

11. De Bruyne S, Van Damme N, Smeets P, et al. Value of DCE-MRI and FDG-PET/ CT in the prediction of response to preoperative chemotherapy with bevacizumab for colorectal liver metastases. British journal of cancer 2012; 106(12): 1926-33.

12. Whiting PF, Rutjes AW, Westwood ME, et al. QUADAS-2: a revised tool for the quality assessment of diagnostic accuracy studies. Ann Intern Med 2011; 155(8): 52936.

13. Moher D, Liberati A, Tetzlaff J, Altman DG, Group P. Preferred reporting items for systematic reviews and meta-analyses: the PRISMA statement. BMF 2009; 339: b2535.

14. Abbadi RA, Sadat U, Jah A, et al. Improved long-term survival after resection of colorectal liver metastases following staging with FDG positron emission tomography. $\mathcal{F}$ Surg Oncol 2014; 110 (3): 313-9.

15. Ayez N, de Ridder J, Wiering B, Oyen WJ, de Wilt JH, Verhoef C. Preoperative FDG-PET-scan in patients with resectable colorectal liver metastases does not improve overall survival: a retrospective analyses stratified by clinical risk score. Dig Surg 
2013; 30(4-6): 451-8.

16. Bender H, Bangard N, Metten N, et al. Possible role of FDG-PET in the early prediction of therapy outcome in liver metastases of colorectal cancer. Hybridoma 1999; 18(1): 87-91.

17. Burger IA, Schwarz EI, Samarin A, Breitenstein S, Weber A, Hany TF. Correlation between therapy response assessment using FDG PET/CT and histopathologic tumor regression grade in hepatic metastasis of colorectal carcinoma after neoadjuvant therapy. Ann Nucl Med 2013; 27(2): 177-83.

18. Buvat I, Necib H, Garcia C, et al. Lesion-based detection of early chemosensitivity using serial static FDG PET/CT in metastatic colorectal cancer. Eur $\mathcal{F}$ Nucl Med Mol Imaging 2012; 39(10): 1628-34.

19. Bystrom P, Berglund A, Garske U, et al. Early prediction of response to first-line chemotherapy by sequential [18F]-2-fluoro-2-deoxy-D-glucose positron emission tomography in patients with advanced colorectal cancer. Ann Oncol 2009; 20(6): 1057 61 .

20. Correa-Gallego C, Gavane S, Grewal R, et al. Prospective evaluation of 18F-fluorodeoxyglucose positron emission tomography in patients receiving hepatic arterial and systemic chemotherapy for unresectable colorectal liver metastases. $H P B(O x-$ ford) $2015 ; \mathbf{1 7}(7): 644-50$.

21. Gui Y, Zhang XP, Sun YS, Tang L, Shen L. Apparent diffusion coefficient: potential imaging biomarker for prediction and early detection of response to chemotherapy in hepatic metastases. Radiology 2008; 248(3): 894-900.

22. de Geus-Oei LF, Vriens D, van Laarhoven HW, van der Graaf WT, Oyen WJ. Monitoring and predicting response to therapy with 18F-FDG PET in colorectal cancer: a systematic review. 7 Nucl Med 2009; 50 Suppl 1: 43S-54S.

23. de Geus-Oei LF, Wiering B, Krabbe PF, Ruers TJ, Punt GJ, Oyen WJ. FDG-PET for prediction of survival of patients with metastatic colorectal carcinoma. Ann Oncol 2006; 17(11): 1650-5.

24. Dimitrakopoulou-Strauss A, Strauss LG, Burger C, et al. Prognostic aspects of 18F-FDG PET kinetics in patients with metastatic colorectal carcinoma receiving FOLFOX chemotherapy. 7 Nucl Med 2004; 45(9): 1480-7.

25. Dimitrakopoulou-Strauss A, Strauss LG, Rudi J. PET-FDG as predictor of therapy response in patients with colorectal carcinoma. Q7 Nucl Med 2003; 47(1): 8-13.

26. Dimitrakopoulou-Strauss A, Strauss LG, Schlag P, et al. Fluorine-18-fluorouracil to predict therapy response in liver metastases from colorectal carcinoma. Fournal of nuclear medicine : official publication, Society of Nuclear Medicine 1998; 39(7): 1197-202.

27. Glazer ES, Beaty K, Abdalla EK, Vauthey JN, Curley SA. Effectiveness of positron emission tomography for predicting chemotherapy response in colorectal cancer liver metastases. Archives of surgery (Chicago, Ill : 1960) 2010; 145(4): 340-5; discussion 5.

28. Hendlisz A, Golfinopoulos V, Deleporte A, et al. Preoperative chemosensitivity testing as Predictor of Treatment benefit in Adjuvant stage III colon cancer (PePiTA): protocol of a prospective BGDO (Belgian Group for Digestive Oncology) multicentric study. BMC Cancer 2013; 13: 190.

29. Hendlisz A, Golfinopoulos V, Garcia C, et al. Serial FDG-PET/CT for early outcome prediction in patients with metastatic colorectal cancer undergoing chemotherapy. Annals of oncology : official journal of the European Society for Medical Oncology 2012; $23(7):$ 1687-93. 
30. Hirashima Y, Yamada Y, Tateishi U, et al. Pharmacokinetic parameters from 3-Tesla DCE-MRI as surrogate biomarkers of antitumor effects of bevacizumab plus FOLFIRI in colorectal cancer with liver metastasis. Int 7 Cancer 2012; 130(10): 2359-65.

31. Lau LF, Williams DS, Lee ST, Scott AM, Christophi C, Muralidharan V. Metabolic response to preoperative chemotherapy predicts prognosis for patients undergoing surgical resection of colorectal cancer metastatic to the liver. Ann Surg Oncol 2014; 21(7): 2420-8.

32. Lee DH, Lee JM, Hur BY, et al. Colorectal Cancer Liver Metastases: Diagnostic Performance and Prognostic Value of PET/MR Imaging. Radiology 2016: 151975.

33. Lee SJ, Seo HJ, Kang KW, et al. Clinical Performance of Whole-Body 18F-FDG PET/Dixon-VIBE, T1-Weighted, and T2-Weighted MRI Protocol in Colorectal Cancer. Clin Nucl Med 2015; 40(8): e392-8.

34. Lv WF, Han JK, Cheng DL, Zhou CZ, Ni M, Lu D. CT Perfusion Imaging Can Predict Patients' Survival and Early Response to Transarterial Chemo-Lipiodol Infusion for Liver Metastases from Colorectal Cancers. Korean journal of radiology 2015; 16(4): 810-20.

35. Maisonobe JA, Garcia CA, Necib H, et al. Comparison of PET metabolic indices for the early assessment of tumour response in metastatic colorectal cancer patients treated by polychemotherapy. Eur f Nucl Med Mol Imaging 2013; 40(2): 166-74.

36. McIntyre DJ, Howe FA, Ladroue C, Lofts F, Stubbs M, Griffiths JR. Can localised (19)F magnetic resonance spectroscopy pharmacokinetics of 5FU in colorectal metastases predict clinical response? Cancer Chemother Pharmacol 2011; 68(1): 29-36.

37. Moehler M, Dimitrakopoulou-Strauss A, Gutzler F, Raeth U, Strauss LG, Stremmel W. 18F-labeled fluorouracil positron emission tomography and the prognoses of colorectal carcinoma patients with metastases to the liver treated with 5-fluorouracil. Cancer 1998; $83(2):$ 245-53.

38. O'Connor JP, Rose CJ, Jackson A, et al. DCE-MRI biomarkers of tumour heterogeneity predict CRC liver metastasis shrinkage following bevacizumab and FOLFOX-6. British journal of cancer 2011; 105(1): 139-45.

39. Ricotta R, Vanzulli A, Moroni M, et al. Magnetic resonance imaging as an early indicator of clinical outcome in patients with metastatic colorectal carcinoma treated with cetuximab or panitumumab. Clinical colorectal cancer 2013; 12(1): 45-53.

40. Smith FW, Heys SD, Evans NT, et al. Pattern of 2-deoxy-2-[18F]-fluro-D-glucose accumulation in liver tumours: primary, metastatic and after chemotherapy. Nucl Med Commun 1992; 13(3): 193-5.

41. Tam HH, Collins DJ, Brown G, et al. The role of pre-treatment diffusion-weighted MRI in predicting long-term outcome of colorectal liver metastasis. Br 7 Radiol 2013; 86(1030): 20130281.

42. Yip VS, Poston GJ, Fenwick SW, Wieshmann H, Athwal T, Malik HZ. FDG-PETCT is effective in selecting patients with poor long term survivals for colorectal liver metastases. Eur f Surg Oncol 2014; 40(8): 995-9.

43. Ahn SJ, Kim JH, Park SJ, Han JK. Prediction of the therapeutic response after FOLFOX and FOLFIRI treatment for patients with liver metastasis from colorectal cancer using computerized CT texture analysis. Eur f Radiol 2016; 85(10): 1867-74.

44. Heijmen L, ter Voert EE, Oyen WJ, et al. Multimodality imaging to predict response to systemic treatment in patients with advanced colorectal cancer. PLoS One 2015; 10(4): e0120823. 
45. Huellner MW, Hennedige TP, Winterhalder R, et al. Prognostic value of different CT measurements in early therapy response evaluation in patients with metastatic colorectal cancer. Cancer imaging : the official publication of the International Cancer Imaging Society 2012; 12: 212-24.

46. Joo I, Lee JM, Kim KW, Klotz E, Han JK, Choi BI. Liver metastases on quantitative color mapping of the arterial enhancement fraction from multiphasic CT scans: evaluation of the hemodynamic features and correlation with the chemotherapy response. Eur 7 Radiol $2011 ; \mathbf{8 0}$ (3): e278-83.

47. Kim DH, Kim SH, Im SA, et al. Intermodality comparison between 3D perfusion GT and 18F-FDG PET/CT imaging for predicting early tumor response in patients with liver metastasis after chemotherapy: preliminary results of a prospective study. Eur f Radiol 2012; 81(11): 3542-50.

48. Koh DM, Scurr E, Collins D, et al. Predicting response of colorectal hepatic metastasis: value of pretreatment apparent diffusion coefficients. AfR Am $\mathcal{J}$ Roentgenol 2007; 188(4): $1001-8$.

49. Liang HY, Huang YQ, Yang ZX, Ying D, Zeng MS, Rao SX. Potential of MR histogram analyses for prediction of response to chemotherapy in patients with colorectal hepatic metastases. Eur Radiol 2015.

50. Mertens J, De Bruyne S, Van Damme N, et al. Standardized added metabolic activity (SAM) IN (1)(8)F-FDG PET assessment of treatment response in colorectal liver metastases. Eur 7 Nucl Med Mol Imaging 2013; 40(8): 1214-22.

51. Rao SX, Lambregts DM, Schnerr RS, et al. CT texture analysis in colorectal liver metastases: A better way than size and volume measurements to assess response to chemotherapy? United European Gastroenterol 7 2016; 4(2): 257-63.

52. Raza SA, Funicelli L, Sohaib SA, et al. Assessment of colorectal hepatic metastases by quantitative T2 relaxation time. Eur $\mathcal{J}$ Radiol 2012; 81(4): e536-40.

53. Seyal AR, Parekh K, Arslanoglu A, et al. Performance of tumor growth kinetics as an imaging biomarker for response assessment in colorectal liver metastases: correlation with FDG PET. Abdom Imaging 2015; 40(8): 3043-51.

54. Tampellini M, Gned D, Baratelli C, et al. Changes in hepatic perfusion assessed by dynamic contrast enhanced MRI, associated with morphologic evaluation, in patients with liver metastases from colorectal cancer treated with first-line chemotherapy. Radiol Med 2016.

55. van Laarhoven HW, Klomp DW, Rijpkema M, et al. Prediction of chemotherapeutic response of colorectal liver metastases with dynamic gadolinium-DTPA-enhanced MRI and localized 19F MRS pharmacokinetic studies of 5-fluorouracil. NMR in biomedicine 2007; 20(2): 128-40.

56. Vriens D, van Laarhoven HW, van Asten JJ, et al. Chemotherapy response monitoring of colorectal liver metastases by dynamic Gd-DTPA-enhanced MRI perfusion parameters and 18F-FDG PET metabolic rate. 7 Nucl Med 2009; 50(11): 1777-84.

57. Koh DM, Takahara T, Imai Y, Collins DJ. Practical aspects of assessing tumors using clinical diffusion-weighted imaging in the body. Magn Reson Med Sci 2007; 6(4): 211-24.

58. Garcia-Figueiras R, Padhani AR, Beer AJ, et al. Imaging of Tumor Angiogenesis for Radiologists--Part 1: Biological and Technical Basis. Current problems in diagnostic radiology 2015; 44(5): 407-24.

59. Hanahan D, Weinberg RA. Hallmarks of cancer: the next generation. 
Cell $2011 ; \mathbf{1 4 4}(5):$ 646-74.

60. Garcia-Figueiras R, Padhani AR, Beer AJ, et al. Imaging of Tumor Angiogenesis for Radiologists--Part 2: Clinical Utility. Current problems in diagnostic radiology 2015; 44(5): 425-36.

61. Harrison L, Blackwell K. Hypoxia and anemia: factors in decreased sensitivity to radiation therapy and chemotherapy? Oncologist 2004; 9 Suppl 5: 31-40.

62. Dinc NS, Aydin K, Odabas H, et al. Pretreatment PET/CT Standardized Uptake Values Play a Role in Predicting Response to Treatment and Survival in Patients with Small Cell Lung Cancer. Oncol Res Treat 2016; 39(3): 130-4.

63. Liu J, Dong M, Sun X, Li W, Xing L, Yu J. Prognostic Value of 18F-FDG PET/CT in Surgical Non-Small Cell Lung Cancer: A Meta-Analysis. PLoS One 2016; 11(1): e0146195.

64. Liu Y, Bai R, Sun H, Liu H, Zhao X, Li Y. Diffusion-weighted imaging in predicting and monitoring the response of uterine cervical cancer to combined chemoradiation. Clin Radiol 2009; 64(11): 1067-74.

65. Ho JC, Allen PK, Bhosale PR, et al. Diffusion-Weighted Magnetic Resonance Imaging as a Predictor of Outcome in Cervical Cancer After Chemoradiation. Int $\mathcal{f}$ Radiat Oncol Biol Phys 2017; 97(3): 546-53.

66. Onal C, Erbay G, Guler OC. Treatment response evaluation using the mean apparent diffusion coefficient in cervical cancer patients treated with definitive chemoradiotherapy. 7 Magn Reson Imaging 2016; 44(4): 1010-9.

67. Jones RG, Thompson CB. Tumor suppressors and cell metabolism: a recipe for cancer growth. Genes $\mathcal{E}$ development 2009; 23(5): 537-48.

68. Hurwitz H, Fehrenbacher L, Novotny W, et al. Bevacizumab plus irinotecan, fluorouracil, and leucovorin for metastatic colorectal cancer. $\mathcal{N}$ Engl $\mathcal{J}$ Med 2004; 350(23): 2335-42.

69. Trillet-Lenoir V, Freyer G, Kaemmerlen P, et al. Assessment of tumour response to chemotherapy for metastatic colorectal cancer: accuracy of the RECIST criteria. $\mathrm{Br}$ 7 Radiol 2002; 75(899): 903-8.

70. Egger ME, Cannon RM, Metzger TL, et al. Assessment of chemotherapy response in colorectal liver metastases in patients undergoing hepatic resection and the correlation to pathologic residual viable tumor. Fournal of the American College of Surgeons 2013; 216(4): 845-56; discussion 56-7.

71. Jaffe CG. Measures of response: RECIST, WHO, and new alternatives. $\mathcal{f}$ Clin Oncol 2006; $24(20): 3245-51$.

72. Korn EL, Freidlin B, Abrams JS. Overall survival as the outcome for randomized clinical trials with effective subsequent therapies. F Clin Oncol 2011; 29(17): 2439-42.

73. Zhuang SH, Xiu L, Elsayed YA. Overall survival: a gold standard in search of a surrogate: the value of progression-free survival and time to progression as end points of drug efficacy. Cancer journal 2009; 15(5): 395-400. 


\section{Whole liver GT texture analysis to predict the development of colorectal liver metastases - A multicentre study}

Rianne CJ Beckers, Doenja MJ Lambregts, Roald S Schnerr, Monique Maas, Sheng-Xiang Rao, Alfons GH Kessels, Thomas Thywissen, Geerard L Beets, Stefano Trebeschi, Janneke B Houwers, Cornelis H Dejong, Cornelis Verhoef, Regina GH Beets-Tan

Published in:

European Journal of Radiology 2017 Jul; 92: 64-71 


\section{Abstract}

\section{Objectives}

CT texture analysis has shown promise to differentiate colorectal cancer patients with/without hepatic metastases. Aim was to investigate whether whole-liver CT texture analysis can also predict the development of colorectal liver metastases.

\section{Material and methods}

Retrospective multicentre study $(\mathrm{n}=165)$. Three subgroups were assessed: $\mathrm{pa}-$ tients $[\mathrm{A}]$ without metastases $(\mathrm{n}=57),[\mathrm{B}]$ with synchronous metastases $(\mathrm{n}=54)$ and [C] who developed metastases within $\leq 24$ months $(n=54)$. Whole-liver texture analysis was performed on primary staging CT. Mean grey-level intensity, entropy and uniformity were derived with different filters $(\sigma 0.5-2.5)$. Univariable logistic regression (group A vs. B) identified potentially predictive parameters, which were tested in multivariable analyses to predict development of metastases (group A vs. C), including subgroup analyses for early ( $\leq 6$ months), intermediate (7-12 months) and late (13-24 months) metastases.

\section{Results}

Univariable analysis identified uniformity $(\sigma 0.5)$, sex, tumour site, nodal stage and carcinoembryonic antigen as potential predictors. Uniformity remained a significant predictor in multivariable analysis to predict early metastases (OR 0.56). None of the parameters could predict intermediate/late metastases.

\section{Conclusion}

Whole-liver CT-texture analysis has potential to predict patients at risk of developing early liver metastases $\leq 6$ months, but is not robust enough to identify patients at risk of developing metastases at later stage. 


\section{Introduction}

Survival in colorectal cancer (CRC) is influenced by several factors, including the local T- and N-stage (tumour- and nodal stage), age and $\operatorname{sex}^{1,2}$. The most important factor, however, is the presence of metastases. Approximately $20 \%$ of patients have metastatic disease at time of diagnosis, with the liver being the most common site of metastases $(77 \%)^{3-5}$. Another $5 \%$ of patients with primary non-metastatic disease develop metachronous metastases within the first year, increasing to up to $15 \%$ at five-year follow-up ${ }^{2}$. Several strategies have been explored to predict which patients are at risk of developing metachronous metastases. By identifying these patients, a different strategy with additional chemotherapy or intensified follow-up might be chosen. A known predictor for the development of colorectal metastases is an increased carcinoembryonic antigen (CEA) level ${ }^{6}$. Other factors are higher T-stage, lymph node metastases and male sex ${ }^{3,7,8}$. From an imaging perspective, a potentially promising tool is CT-texture analysis. Texture analysis refers to a mathematical approach to analyse variations in grey-level intensities within an image or region of interest to provide quantitative measures ('texture features') reflecting spatial heterogeneity ${ }^{9-11}$. Although several methods of texture analysis have been described in literature, the most commonly used technique is statistical-based texture analysis. The most basic form of statistical texture analysis involves first-order statistics, which focuses on the distribution of grey-level frequencies within an image, derived from the histogram of pixel intensities ${ }^{11-13}$. Commonly reported texture features include the 'mean intensity', 'entropy' and 'uniformity'. The mean intensity reflects the average pixel value or 'intensity' of a region of interest. Entropy is a measure that gives an indication of the irregularity of the grey-level distribution, while conversely the uniformity is indicative of its regularity. A higher entropy (and low uniformity) typically reflects a more "heterogeneous" distribution of pixels (and thus a more heterogeneous underlying tissue structure) while on the other hand a high uniformity is associated with a more "homogeneous" distribution of pixels (and therefore a more homogeneous tissue structure).

Single-centre studies have demonstrated that changes in the CT-texture of the liver (increase in entropy and decrease in uniformity) can be observed when the liver is affected by metastatic disease, thereby suggesting that these texture features have potential to differentiate between patients with and without colorectal liver metastases ${ }^{10,14}$. It has been suggested that these changes may be related to the presence of occult micro metastases throughout the liver and/or diffuse changes 
in hepatic perfusion caused by the presence of metastatic liver disease ${ }^{15-19}$. Hypothetically, similar changes - albeit to a lesser extent - may already be present in an earlier phase, i.e. before the metastatic lesions become visible on morphological CT (computed tomography) assessment. If this were the case, CT-texture may also have potential as an imaging biomarker to predict upfront (at the time of primary staging) which patients who initially present without metastases are at risk of developing metastases at a later stage. This would be beneficial as CT is to date still the most widely used modality for staging of liver metastases and texture parameters can readily be obtained from routinely acquired clinical CT examinations.

The aim of this study was to evaluate in a multicentre study setting whether CT-texture analysis of the apparently non-diseased liver at the time of primary diagnosis has potential to predict patients at risk of developing liver metastases at a later stage.

\section{Material and Methods}

\section{Patients}

This multicentre study analysed 165 patients (106 male, 59 female, median age 64 years, range 16-86 years) who were treated for colorectal cancer in one of three university hospitals between December 2006 and October 2013 (a time period selected based on adequate documentation of clinical patient data, availability of consistent quality imaging data and allowing for an adequate clinical follow-up period of at least 2 years). Patients routinely underwent contrast-enhanced liver or abdominal CT as part of their primary staging work-up. According to our country's national law, institutional review board approval and informed consent were not required for this retrospective study. Patients were divided into three \pm equally sized subgroups:

1. Group A, the 'no metastases group', consisted of 57 patients who had no evidence of liver metastasis at primary staging, or during $\geq 24$ months of follow-up (established by means of clinical, laboratory (CEA) and imaging follow up).

2. Group B, the 'synchronous metastases group', consisted of 54 patients 
who presented with synchronous liver metastases at the time of primary staging. The presence of metastases was confirmed by pathology (biopsy/surgery) in 17 patients, by corresponding positive findings on PET-CT in 7 patients, and by imaging follow-up in the other 30 patients who all had unresectable metastases, which were palliatively managed.

3. Group $\mathrm{C}$ the 'metachronous metastases group', consisted of 54 patients who had no evidence of metastatic disease at primary staging but developed liver metastases (i.e. new and/or growing lesions on follow-up imaging) within 24 months after primary staging (median interval 12 months, range 2-24). In 21 patients, these lesions were histopathologically proven to be colorectal liver metastases.

Inclusion criteria consisted of (a) histopathologically confirmed colorectal adenocarcinoma; (b) no evidence of extrahepatic metastatic sites on primary or follow-up imaging (CT, MRI and/or PET-CT); (c) availability of a primary staging CT including a portal venous phase; (d) no history of previous liver surgery; (e) no history of previous systemic treatment (chemotherapy); $(f)$ no history of diffuse liver disease such as steatosis or cirrhosis; ( $g$ ) no history of diffuse hepatic metastases, as this would leave too little 'normal' liver parenchyma to perform whole-liver texture analysis. Clinical follow-up (after resection of the primary tumour) was performed according to routine clinical guidelines as advocated in the participating centres. This included routine (3-6 monthly) clinical examination, CEA testing and follow-up imaging with CT, MRI and/or FDG-PET when indicated.

\section{CT Acquisition}

A contrast-enhanced CT was performed as part of the routine work-up for CRC in all centres. All CT scans included a portal venous phase (PVP) scan of the liver and were acquired using different CT scanners (Philips Brilliance 64, Philips Medical Systems, Best, The Netherlands; Siemens Somatom Sensation 16, Somatom Sensation 64, Somatom Definition AS or Somatom Definition Flash, Siemens Healthcare, Erlangen, Germany; Toshiba Aquilion 64, Toshiba Medical Systems, Tokyo, Japan; GE Lightspeed VCT 64, GE Healthcare, Little Chalfont, United Kingdom). PVP images were routinely obtained with a tube voltage of $100-120 \mathrm{kVp}$. The contrast medium (Ultravist 300-370mgI/ml; Iopromide, Bayer Healthcare, Berlin, Germany or Visipaque $320 \mathrm{mgI} / \mathrm{ml}$; Iopromide, GE 
Healthcare, Eindhoven, The Netherlands) was prewarmed to $37^{\circ} \mathrm{C}\left(99^{\circ} \mathrm{F}\right)$ and administered intravenously as a bolus injection of $100-150 \mathrm{ml}$ at a rate of $1,8-$ $3,5 \mathrm{ml} / \mathrm{s}$, followed by a saline flush of 20-40 $\mathrm{ml}$. The scan delay for the PVP was set at 70-80 sec. Slice thickness was $5 \mathrm{~mm}$ in two of the three study centres. In the third centre the original slice thickness was $3 \mathrm{~mm}$, which was reconstructed to 5 mm for assessment in this study.

\section{Image assessment}

CT images were transferred to an offline workstation for texture analyses and analysed using the open source software tool MRIcron ${ }^{20}$. An experienced reader (RB) manually traced the surface of the whole liver on the PVP images on each consecutive slice including all normal (apparently non-diseased) liver parenchyma, excluding the border of the liver, any visible lesions (any benign focal liver lesions or metastases), the caudate lobe (as this is often ill defined and difficult to discern from the vena cava), the inferior vena cava and large portal and hepatic veins to obtain volumes of interest (VOIs) of the whole liver volume, according to methods previously reported (Figure 1$)^{10,14}$.

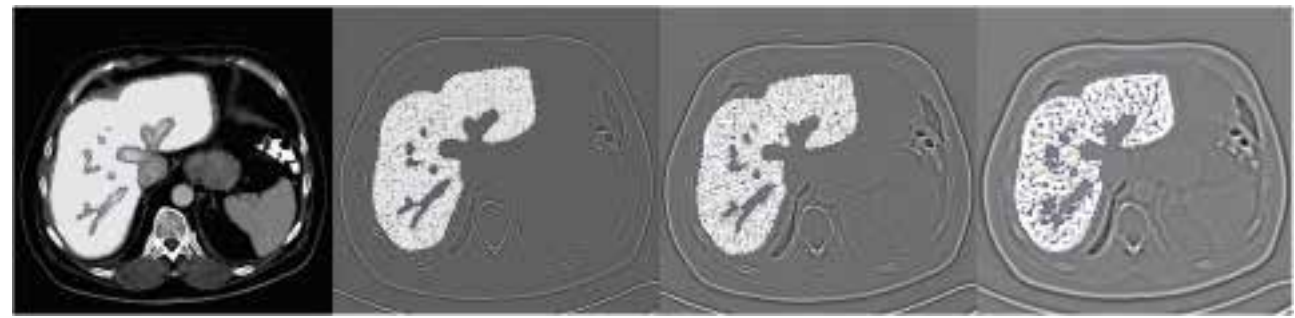

Figure 1. Example of VOI's drawn on a portal venous phase computed tomography $(\mathrm{CT})$ image of the liver with no filtration $(\mathrm{a})$, fine filtration $(0.5)(\mathbf{b})$, medium filtration $(1.5)(c)$ and coarse filtration $(2.5)(d)$. The border of the liver, any visible lesions, the inferior vena cava and large portal and hepatic veins were excluded.

\section{Texture analysis}

Texture analysis was performed using a dedicated script written in MATLAB (The MathWorks Inc., Natick, MA, 2000) by one of the authors (RS), according to methods previously reported ${ }^{14,21}$. It comprised two main stages: (a) image filtration, followed by (b) quantification of texture. Fine image filtration highlights very small structures (in the order of 1-2 mm), while coarse image filtration highlights larger structures (in the order of $6 \mathrm{~mm}$ ). For image filtration, a Laplacian of Gaussian $(\mathrm{LoG})$ band-pass filter was applied to the VOI using sigma $(\sigma)$ values 
of 0.5 (fine scale filtration), 1.5 (medium scale filtration) and 2.5 (coarse scale filtration). For each CT scan with a resolution different than $0.84 \mathrm{~mm}$, the value of $\sigma$ was modified to keep the physical size (in $\mathrm{mm}$ ) of the filter constant. The texture of the liver parenchyma was characterized by mean grey-level intensity (M), entropy (E) and uniformity $(\mathbf{U})$. The mathematical analysis technique used for this study is described in detail in the Appendix.

\section{Statistical analysis}

Statistical analyses were performed using the Statistical Package for the Social Sciences (IBM Corp. Released 2012. IBM SPSS Statistics for Windows, Version 21.0. Armonk, NY: IBM Corp.) and Stata (StataCorp. 2009. Stata Statistical Software: Release 11. College Station, TX: StataCorp LP). Baseline patient characteristics were assessed using descriptive statistics. Further analysis comprised two steps:

1. Step 1: univariable multilevel logistic regression analyses were performed to identify potentially predictive clinical and texture parameters $(P<0.1)$ to differentiate between group A (no metastases) and group B (synchronous metastases). Multilevel analyses per CT scanner ( $\mathrm{n}=10$ scanners, 3-4 different scanners per centre) were performed to account for potential differences in scan protocol (e.g. contrast timing, $\mathrm{kVp}$ ) and CT software and hardware between scanners/centres.

2. Step 2: multivariable multilevel logistic regression analysis was performed to test the predictive value of the clinical and texture parameters identified in step 1 to differentiate between patients without metastases (group A) and patients who later developed metastases (group C). CT scanner was chosen as level for the multilevel analysis. Results were separately analysed for patients who developed metastases within 6 months (early), between 7-12 months (intermediate) and between 13-24 months (late).

Receiver operating characteristics (ROG) curves were constructed to determine the diagnostic performance of the various clinical/texture features in predicting the development of liver metastases. The diagnostic performance of different combinations of parameters was assessed using predicted probabilities derived from the logistic regression as input variables. Differences in diagnostic perfor- 
mance between the different approaches were compared using the method described by Delong et $\mathrm{al}^{22}$.

\section{Results}

\section{Patient characteristics}

Patient characteristics are given in Table 1 . The primary tumour was located in the colon in 88 patients and in the rectum in the other 77 patients. Fifty-seven patients had no metastases (during a follow-up of at least 24 months after primary diagnosis); 54 patients had synchronous metastases; 11 patients developed metastases within 6 months, 20 within 7-12 months and 23 after 13-24 months. 
Table 1. Baseline characteristics of the 165 study patients

\begin{tabular}{|c|c|c|c|c|}
\hline \multirow[b]{2}{*}{ Characteristics } & \multicolumn{3}{|c|}{ Group } & \multirow[b]{2}{*}{ Total } \\
\hline & $\mathrm{A}(\mathrm{N}=57)$ & $\mathrm{B}(\mathrm{N}=54)$ & $\mathrm{C}(\mathrm{N}=54)$ & \\
\hline \multicolumn{5}{|l|}{ Age (y) } \\
\hline Mean & 61 & 66 & 64 & 64 \\
\hline Range & $16-86$ & $22-85$ & $46-81$ & $16-86$ \\
\hline \multicolumn{5}{|l|}{ Sex } \\
\hline Male & $32(56.1)$ & $40(74.1)$ & $34(63.0)$ & $106(64.2)$ \\
\hline Female & $25(43.9)$ & $14(25.9)$ & $20(37.0)$ & $59(35.8)$ \\
\hline \multicolumn{5}{|l|}{ Primary tumour site } \\
\hline Rectum & $34(59.6)$ & $19(35.2)$ & $24(44.4)$ & 77 (46.7) \\
\hline Colon & $23(40.4)$ & $35(64.8)$ & $30(55.6)$ & $88(53.3)$ \\
\hline \multicolumn{5}{|l|}{ Tumour stage* } \\
\hline $\mathrm{T} 1$ & $1(1.8)$ & 0 & 0 & $1(0.6)$ \\
\hline $\mathrm{T} 2$ & $8(14.0)$ & $2(3.7)$ & $3(5.6)$ & $13(7.9)$ \\
\hline $\mathrm{T} 3$ & $42(73.7)$ & $42(77.8)$ & $39(72.2)$ & $123(74.5)$ \\
\hline $\mathrm{T} 4$ & $6(10.5)$ & $1(1.9)$ & $12(22.2)$ & $19(11.5)$ \\
\hline \multicolumn{5}{|l|}{ Nodal stage* } \\
\hline N0 & $25(43.9)$ & $15(27.8)$ & $15(27.8)$ & $55(33.3)$ \\
\hline $\mathrm{N} 1-2$ & $32(56.1)$ & $30(55.6)$ & $39(72.2)$ & $101(61.2)$ \\
\hline \multicolumn{5}{|l|}{ Interval until metastases $(\mathrm{m}) \dagger$} \\
\hline & $\mathrm{N} / \mathrm{A}$ & N/A & $12(2-24)$ & N/A \\
\hline \multicolumn{5}{|c|}{ Carcinoembryonic antigen (CEA) at the time of primary diagnosis } \\
\hline Normal $(<5 \mathrm{mcg} / \mathrm{L})$ & $24(42.1)$ & $7(13.0)$ & $20(37.0)$ & $51(30.9)$ \\
\hline Elevated $(\geq 5 \mathrm{mcg} / \mathrm{L})$ & $18(31.6)$ & $39(72.2)$ & $25(46.3)$ & $82(49.7)$ \\
\hline
\end{tabular}

Note. - Unless otherwise indicated, data are numbers of patients and data in parentheses are percentages.

Group A: patients without liver metastasis ( $N=27 / 11 / 19$ per centre);

Group B: patients with synchronous liver metastasis ( $\mathrm{N}=18 / 8 / 28$ per centre);

Group C: patients with liver metastasis occurring within 24 months $(N=30 / 6 / 18$ per centre);

N/A: not applicable

* Primary tumour/nodal stage based on histopathology for patients undergoing direct surgery and based on MRI for patients undergoing neo-adjuvant treatment.

$\dagger$ Median interval between the primary staging CT and the detection of liver metastases. 


\section{Step 1 - Identification of potential predictive parameters}

The mean ( \pm standard deviation) of the texture parameters for the different subgroups are presented in Table 2. Detailed results of the univariable multilevel logistic regression analyses are presented in Table 3 . There is no significant difference within the scanners $(P>0.05)$. Of the texture parameters, uniformity at fine scale filtration $\left(\mathrm{U}_{0.5}\right)$ offered the best results to differentiate between patients without (group A) and patients with synchronous metastases (group B). In addition, nodal status, primary tumour site, sex and CEA were identified as potentially predictive clinical parameters.

\section{Step 2: Prediction of metachronous metastases}

Table 4 shows the results of the multivariable logistic regression of the different parameters identified in step 1 to discriminate between group A (no metastases) and $\mathrm{C}$ (metachronous metastases). For the whole group of patients with metachronous disease neither texture analysis $\left(\mathrm{U}_{0.5}\right)$, nor any of the clinical parameters showed significant predictive value (OR 0.52-1.67, $P=0.16-0.44)$. In the sub-analysis of patients who developed early metastases (within 6 months) $\mathrm{U}_{0.5}$ resulted in an OR of $0.56(P=0.05)$. Representative imaging examples of patients from the no metastases and early metastases group are provided in Figure 2. Nodal stage in this subgroup resulted in an OR of $3.19(P=0.06)$. 


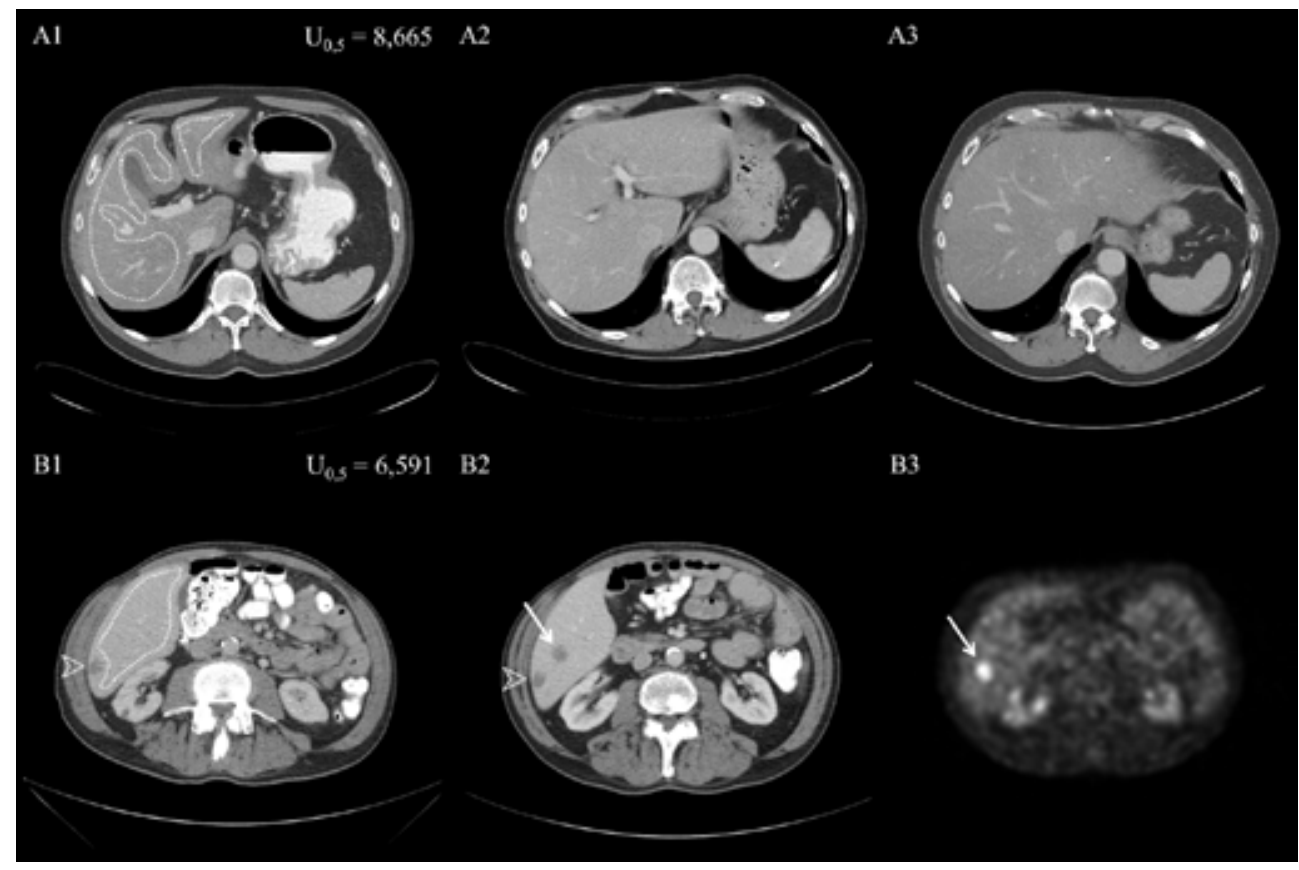

Figure 2. Representative examples of the CT scans of a patient from the no metastases group (upper row, A1-A3) and a patient from the metachronous metastases group (bottom row, B1-B3). The dotted lines represent the delineations of the VOIs used to derive the texture features. On primary staging CT, patient A had no visible liver lesions (A1) and patient $B$ had a haemangioma in segment 6 (arrowhead in B1) that was excluded from the VOI. On the scan performed at six months after diagnosis (A2), as well as a late follow-up scan performed 5 years after diagnosis (A3), patient $A$ remained free of metastases. Patient $B$ developed a metastatic lesion of $17 \mathrm{~mm}$ in segment 6 (arrow in B2, performed 6 months after diagnosis), which was later confirmed on PET (arrow in B3) and pathologically confirmed after resection of the lesion. The haemangioma remained unchanged (arrow in B2) and was negative on PET. On the primary staging CT, uniformity with a fine filter was 8,665 in patient $A$ who remained without metastases, while it was 6,591 in the patient with metachronous metastasis, illustrating that lower uniformity may be used as a marker to predict patients at risk of developing early metastatic disease.

\section{Diagnostic performance to predict metachronous metastases}

ROC-curves illustrating the diagnostic performance of texture and clinical parameters to predict the development of liver metastases are provided in Figure 3. For the whole group of patients with metachronous disease, AUCs to predict the development of metastases ranged between 0.51 and 0.61 for (combinations of) $\mathrm{U}_{0.5}$, and the clinical parameters CEA and nodal stage. For prediction of early metastases (occurring within six months), the $\mathrm{AUC}$ was 0.74 for $\mathrm{U}_{0.5}$ versus $\mathrm{AUC}$ 
0.70 for CEA + N-stage $(P=0.72)$. Combining $\mathrm{U}_{0.5}$ with CEA + N-stage resulted in an AUC of 0.78, which was not a significant improvement compared to either $\mathrm{U}_{0.5}(P=0.53)$ or N-stage + CEA $(P=0.08)$. 


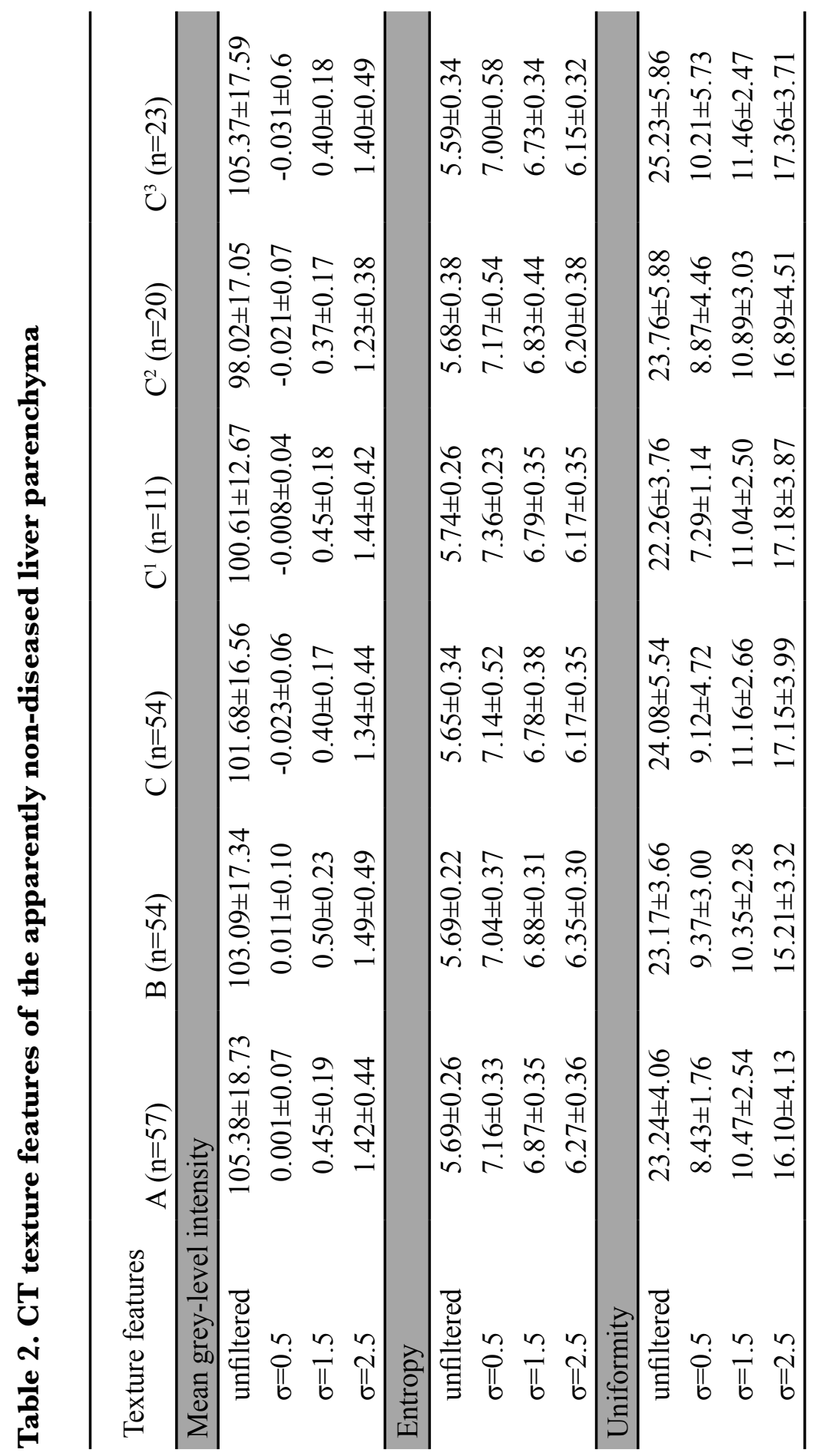




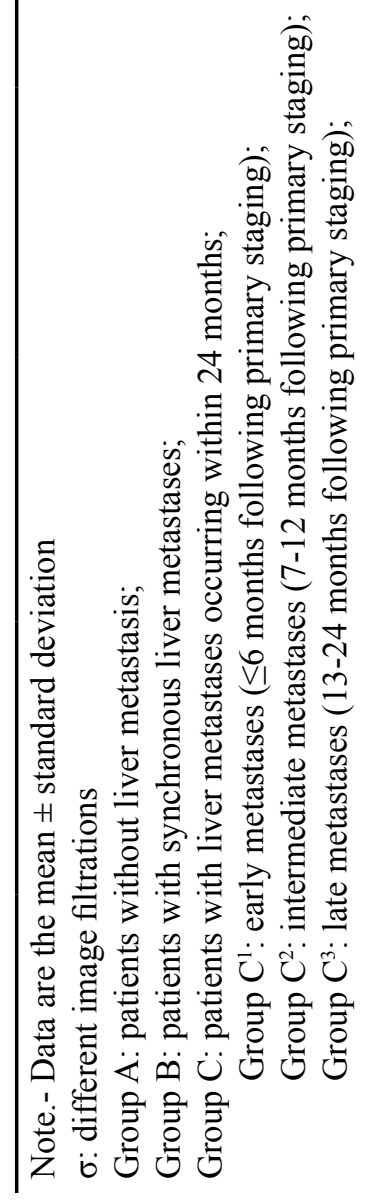


Table 3. Univariable multilevel logistic regression analysis to differentiate between group $A$ and $B$

\begin{tabular}{|c|c|c|}
\hline Parameters & Odds Ratio & $P$ \\
\hline \multicolumn{3}{|l|}{ Mean grey-level intensity } \\
\hline unfiltered & $0.99(0.97-1.01)$ & 0.50 \\
\hline$\sigma=0.5$ & $3.99(0.06-279.24)$ & 0.52 \\
\hline$\sigma=1.5$ & $3.32(0.54-20.64)$ & 0.20 \\
\hline$\sigma=2.5$ & $1.37(0.61-3.10)$ & 0.44 \\
\hline \multicolumn{3}{|l|}{ Entropy } \\
\hline unfiltered & $0.99(0.21-4.60)$ & 0.99 \\
\hline$\sigma=0.5$ & $0.32(0.10-1.05)$ & $0.06^{*}$ \\
\hline$\sigma=1.5$ & $1.14(0.36-3.60)$ & 0.82 \\
\hline$\sigma=2.5$ & $2.00(0.64-6.24)$ & 0.23 \\
\hline \multicolumn{3}{|l|}{ Uniformity } \\
\hline unfiltered & $1.00(0.90-1.10)$ & 0.93 \\
\hline$\sigma=0.5$ & $1.21(0.99-1.46)$ & $0.06^{*}$ \\
\hline$\sigma=1.5$ & $0.98(0.84-1.14)$ & 0.79 \\
\hline$\sigma=2.5$ & $0.94(0.85-1.04)$ & 0.21 \\
\hline Age on diagnosis $(y) \dagger$ & $1.02(0.99-1.05)$ & 0.18 \\
\hline Sex $\dagger+$ & $0.45(0.20-1.00)$ & 0.05 \\
\hline Primary tumour site $\dagger \S$ & $2.72(1.26-5.88)$ & 0.01 \\
\hline Tumour stage & $1.27(0.53-3.06)$ & 0.60 \\
\hline Nodal stage $\dagger$ & $1.52(0.96-2.39)$ & 0.07 \\
\hline Node positive / Node negative & $1.56(0.69-3.52)$ & 0.28 \\
\hline CEA level $(\mathrm{mcg} / \mathrm{L}) \dagger$ & $1.05(1.02-1.09)$ & 0.00 \\
\hline
\end{tabular}

Note. - Data in parentheses are $95 \%$ confidence intervals.

Group A: patients without liver metastasis;

Group B: patients with synchronous liver metastases;

* Since entropy and uniformity are correlated parameters, only uniformity was selected for multivariable logistic regression analysis because of the smaller confidence interval.

$\dagger$ Parameters with $P<.2$ were selected for multivariable logistic regression analysis.

† Male (vs. female)

$\S$ Location in rectum (vs. colon) 


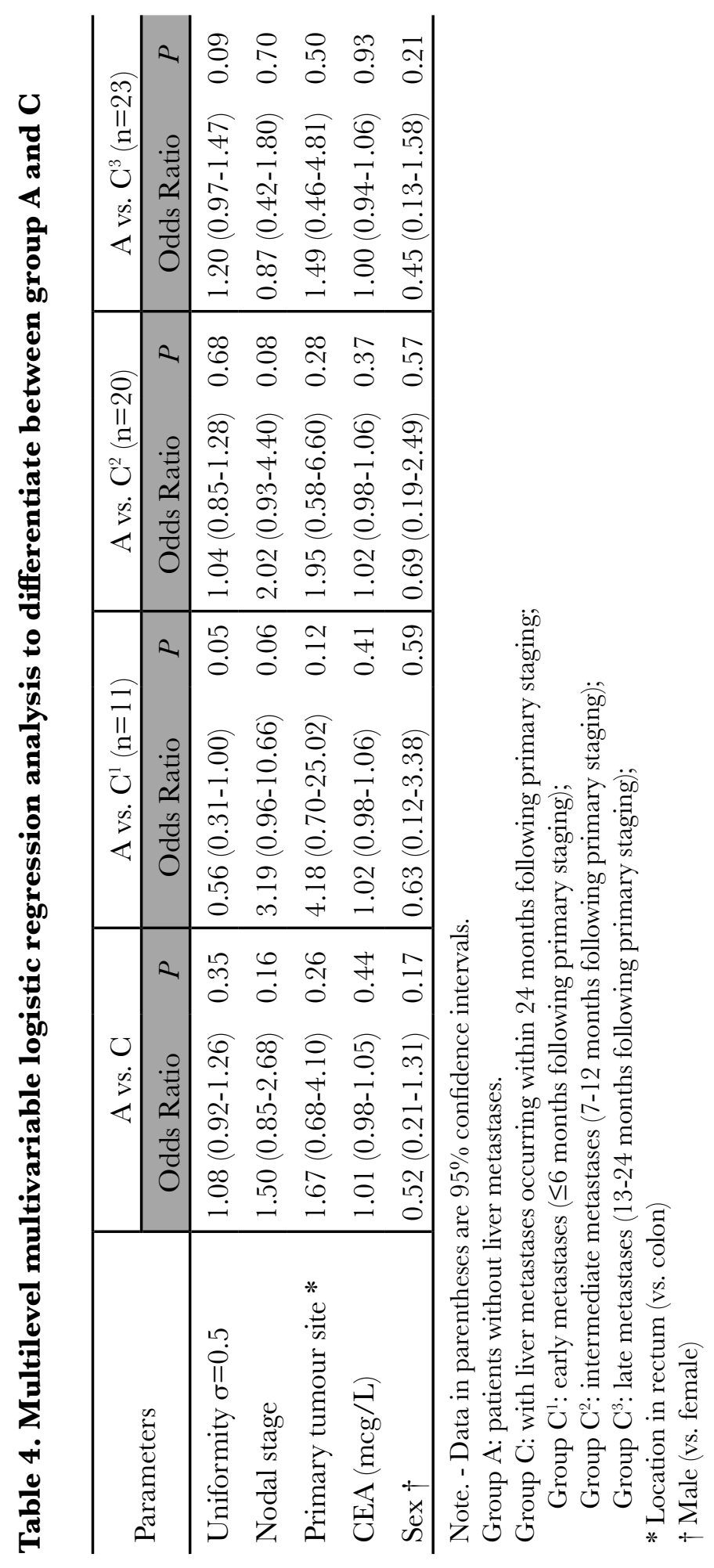



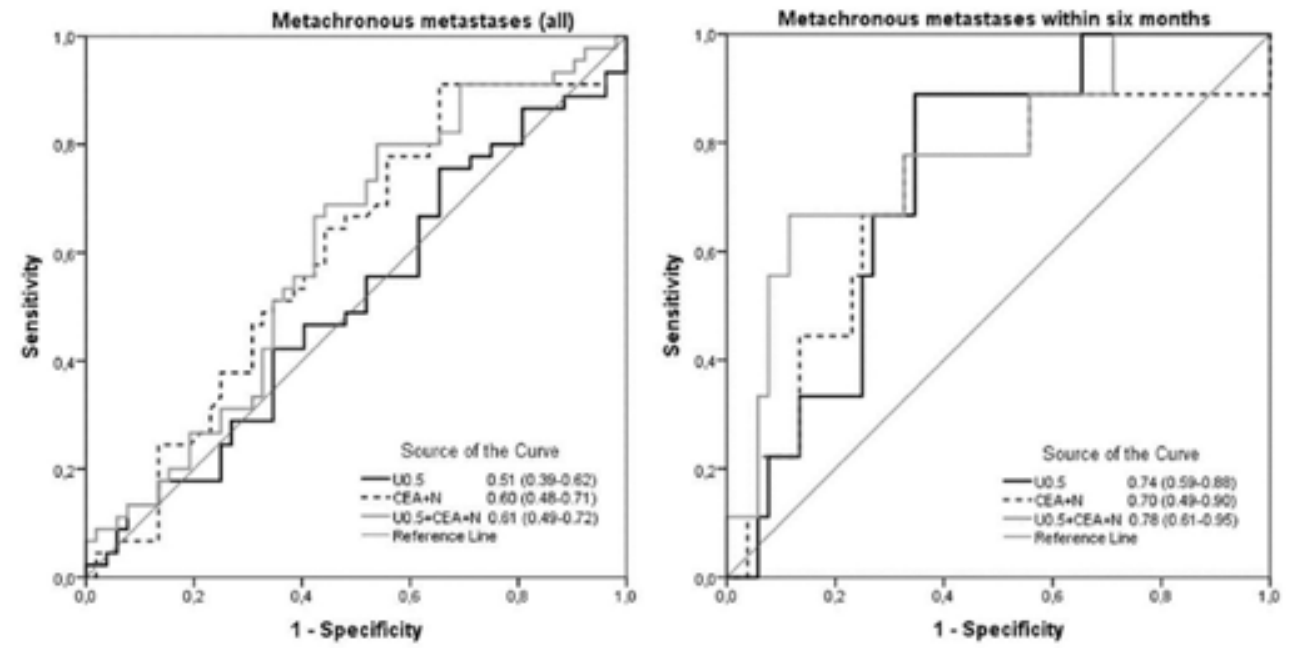

Figure 3. ROG curves illustrating the diagnostic performance of clinical parameters ( $N$-stage and $\mathrm{CEA})$, texture analysis $\left(U_{0.5}\right)$ and a combination of clinical and texture features to predict patients at risk to develop metachronous disease for the whole patient group (left) and for the subgroup of patients who developed metastases within six months.

\section{Discussion}

The aim of our study was to evaluate in a multicentre setting whether CT-texture analysis of the apparently non-diseased liver at the time of primary diagnosis has the potential to predict upfront which patients who initially present without metastases are at risk of developing liver metastases at later stage. Our results suggest that texture analysis has some promise to differentiate patients that will develop liver metastases early ( $\leq 6$ months) after initial diagnosis, but is not robust enough to identify patients at risk to develop metastases after a longer interval (within 7-24 months).

Our findings are in line with those of previous single-centre studies that reported that changes in the overall texture of the liver parenchyma can be observed when metastatic disease is present within the liver. Both Rao et $\mathrm{al}^{14}$ and Ganeshan et $\mathrm{al}^{10}$ reported significant differences in CT-texture between patients with and without liver metastases. Rao et al ${ }^{14}$ also reported a similar subtle change in texture in patients who had no metastases at the time of primary diagnosis but later developed metachronous liver metastases, but the number of patients with metachronous 
disease in their cohort was too small $(n=4)$ to draw any meaningful conclusions. Our current multicentre study follows up on these previous works and confirms that - at least to predict metastases occurring within 6 months - texture analysis may be of added value. In ROG-curve analysis there was a trend towards improved results compared to more well-known clinical markers (CEA $+\mathrm{N}$-stage) with an AUC of 0.78 for texture + clinical markers versus an AUC of 0.70 for only clinical markers, albeit not statistically significant $(P=0.08)$. From a clinical point of view, however, these very early metastases are more considered occult synchronous metastases, that were probably already present but too small to detect by visual assessment on CT at the time of primary staging. Moreover, one could wonder whether these lesions might have been detected if patients would have been imaged with MRI instead of CT, given the known superiority of MRI over CT for the detection of small liver metastase ${ }^{23,24}$. For the prediction of 'true' metachronous metastases occurring at later stage, texture analyses were not beneficial. If in these patients changes were already present within the liver at time of primary diagnosis and staging, they were too small to be detected with texture analyses.

Despite the fact that the texture analysis and the delineation were performed in the same way as previous reports, there are some remarkable discrepancies between the findings ${ }^{10,14,21}$. First, in our study the best results were obtained for texture measures using fine image filtration, whereas previous reports found better results for medium to coarse filters ${ }^{10,14}$. Fine image filtration highlights very small structures (in the order of 1-2 mm), while coarse image filtration highlights larger structures (in the order of $6 \mathrm{~mm}$ ). The size of the structures that can be detected, however, also depends on the chosen slice thickness which influences image noise and intrinsic contrast. Therefore, one could expect a correlation between the slice thickness and the optimal image filtration to detect structures of a certain size. Since the above-mentioned studies (including the current) were performed with CT images of varying slice thickness (ranging between 3-10 mm), this may have contributed to the varying results for different image filtrations between studies. Also, previous studies performed by Ganeshan et al use a single slice, while our report is based on the average of multiple slices resulting in whole liver analysis ${ }^{10,17}$.

Although the exact mechanism is not fully known, changes in liver texture as a result of metastatic involvement have been proposed to be related to changes in liver perfusion or changes on a cellular level caused by the presence of micro metastases ${ }^{16,18,25}$ With this in mind, it would be logical to assume that entropy would increase (more heterogeneous/irregular liver structure) and vice 
versa uniformity would decrease in patients with synchronous metastases and that by extension this effect may also already be observed in patients who later develop metachronous disease. However, as illustrated in Table 2, entropy and uniformity values fluctuated inconsistently between the different subgroups of patients with synchronous, early, intermediate and late metastases for reasons not well understood. Previous studies also found conflicting results; some indeed reported higher entropy and corresponding lower uniformity in patients with metastases $^{10,14}$, while others reported the opposite effect ${ }^{9}$. Further research is therefore needed to understand the complex relations between texture parameters and underlying biological tissue characteristics in these different settings.

Apart from biologic tissue properties, there are also several other factors that may influence texture measures, amongst which the image acquisition parameters. For example, Bezy-Wendling et al reported that texture values are highly dependent on the slice thickness of the CT images ${ }^{26}$. As described above, slice thickness varies considerably between published reports. Moreover, Ganeshan et al reported that timing of acquisition after contrast injection has a considerable effect on entropy and uniformity values (even with slight variations in timing) with typically an increase in entropy and decrease in uniformity over time ${ }^{9}$, ${ }^{27}$. Since contrast timing differs between studies (some used non-enhanced CT and others contrast-enhanced CT with various contrast timings) and even within studies, this will likely also have contributed to the variations in results $9,17,25,28$. Other factors such as contrast volume, $\mathrm{kVp}$ and slice collimation may also affect results, although effects of these items have so far not been specifically addressed in literature. We tried to compensate for such effects by performing a multilevel analysis per CT scanner used in our study (thereby aiming to take into account hardware, software and acquisition protocol related variation between scanners and centres). However, we cannot fully rule out potential confounding effects and more detailed research on the precise effects of acquisition-related factors is therefore urgently needed. All together these issues make it difficult to perform multicentre texture research and ultimately generalize and translate findings to daily use. These issues are also part of the reason why texture analysis is not yet ready for use in clinical practice. Before texture features may truly be used as clinical imaging biomarkers, further standardisation of acquisition- and technical parameters is thus required. Moreover, discrimination threshold values will need to be defined and properly validated. 
There are some other limitations to our study design. First, because we aimed to obtain three equally sized patient cohorts, patients (particularly in the metachronous group, being the least prevalent outcome) are non-consecutive. Second, VOI's were drawn by a single observer, which does not account for potential interobserver variations (though we believe that for whole-liver analysis this effect will probably be limited). Finally, slice thickness was relatively large $(5 \mathrm{~mm})$ and in one of the three centres the slice thickness was reconstructed from an original slice thickness of $3 \mathrm{~mm}$, which may have affected image noise. Finally, as described above, for our study we only looked at CT, as this still represents the most routinely used modality for staging CRC in daily practice. Routine staging with MRI was not performed. For future studies, it will be worthwhile to look at the potential added value of MRI in this regard.

\section{Conclusion}

In conclusion, it is our experience that it is technically challenging to analyse CT-texture in a multicentre setting and fully take into account potential confounding factors such as differences in CT acquisition protocols. Apart from these challenges, our results suggest that CT-texture analysis may have promise as an adjunct to known clinical risk factors such as $\mathrm{N}$-stage and CEA to predict which patients that are at risk of developing liver metastases early ( $\leq 6$ months) after initial diagnosis, but is not robust enough to identify patients at risk of developing metastases at later stage, i.e. within 1-2 years. 


\section{Appendix}

Texture analysis consists of two main stages: (a) image filtration and (b) quantification of texture.

\section{Image filtration:}

For image filtration, a Laplacian of Gaussian (LoG) band-pass filter was chosen. Before applying the filter, regions outside the VOI were set to the average value of the pixels inside the VOI, to prevent non-target regions to influence the analysis. The LoG filter is mathematically defined as $\Delta \mathrm{G}(\mathrm{x}, \mathrm{y})$, with $\Delta$ the Laplace operator and $\mathrm{G}(\mathrm{x}, \mathrm{y})$ a two-dimensional Gaussian. We have chosen to normalize the Gaussian as follows:

$G(x, y)=-e^{-\left(x^{2}+y^{2}\right) /\left(2 \sigma^{2}\right)}$, which results in a LoG filter that is described by

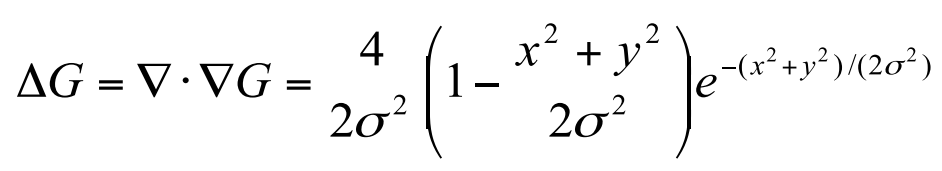

We applied the filter in the Fourier space, as this is less computationally demanding. To calculate the convolution of the data and our filter, we multiplied their Fourier transforms in Fourier space. This has the additional benefit of reducing the discretization errors, as the filter has a larger width in Fourier space. The Fourier transform of the filter is given by

$$
F(\Delta G)=2 \pi \sigma^{2} 4 \pi^{2}\left(k_{x}^{2}+k_{y}^{2}\right) e^{-\pi^{2} 2 \sigma^{2}\left(k_{x}^{2}+k_{y}^{2}\right)}
$$

with $\mathrm{k}_{\mathrm{x}}$ and $\mathrm{k}_{\mathrm{y}}$ in the range $[-0.5,0.5]$. The LoG-filter was applied for a range of $\sigma$ values. The width of the filters in pixels (at the reference resolution of $0.84 \mathrm{~mm}$ ) and $\mathrm{mm}$ is shown in Table 5. For each CT scan with a resolution different than $0.84 \mathrm{~mm}$, the value of $\sigma$ was modified to keep the physical size (in $\mathrm{mm}$ ) of the filter constant. We defined the width of the filter as the distance between the zero crossings (see Figure 4). These occur for $x^{2}+y^{2}=2 \sigma^{2}$, so the total width of the filter is given by $2 \sqrt{2}$ ó . 
Table 5. Filter widths for different values of $\sigma$

\begin{tabular}{ccc}
$\boldsymbol{\sigma}$ [pixels] & Full width [pixels] & Full width $[\mathrm{mm}]$ \\
\hline 0.5 & 1.4 & 1.2 \\
1.5 & 4.2 & 3.6 \\
2.5 & 7.0 & 5.9 \\
\hline
\end{tabular}

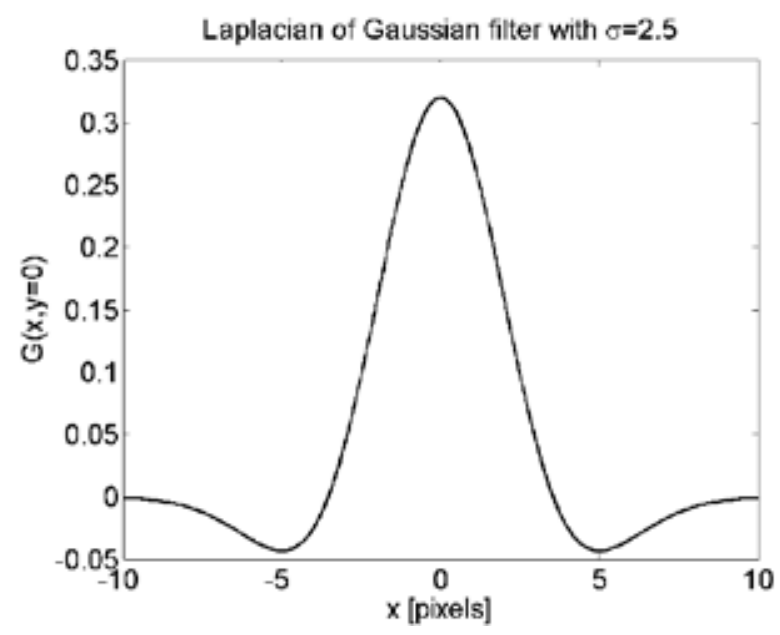

Figure 4. Example of the LoG filter with $\sigma=2.5$

2. Quantification of texture:

For image quantification of texture, mean grey-level intensity, entropy and uniformity were used. These parameters were calculated from a histogram of the points within the VOI with a bin size of 1 HU. From the histogram, the parameters were calculated using:

mean $=\sum_{i=1}^{M} f(i) \cdot h(i)$,

entropy $=-\sum_{i=1}^{M} f(i) \cdot \log _{2}(f(i))$,

uniformity $=1000 \cdot \sum_{i=1}^{M} f(i)^{2}$

where $\mathrm{M}$ is the number of bins in the histogram, $f(i)$ the fraction of the voxels in the vOI in bin number $i$ of the histogram and $h(i)$ the $\mathrm{HU}$ value of bin $i$. The entropy gives an indication of the width of the histogram and the uniformity of the narrowness. 


\section{References}

1. Siegel RL, Miller KD and Jemal A. Cancer statistics, 2015. CA: a cancer journal for clinicians. 2015; 65: 5-29.

2. Manfredi S, Lepage C, Hatem C, Coatmeur O, Faivre J and Bouvier AM. Epidemiology and management of liver metastases from colorectal cancer. Ann Surg. 2006; 244: 254-9.

3. Landreau P, Drouillard A, Launoy G, et al. Incidence and survival in late liver metastases of colorectal cancer. Fournal of gastroenterology and hepatology. 2015; 30: 82-5.

4. van der Pool AE, Damhuis RA, Ijzermans JN, et al. Trends in incidence, treatment and survival of patients with stage IV colorectal cancer: a population-based series. Colorectal Dis. 2012; 14: 56-61.

5. van der Geest LG, Lam-Boer J, Koopman M, Verhoef C, Elferink MA and de Wilt $\mathrm{JH}$. Nationwide trends in incidence, treatment and survival of colorectal cancer patients with synchronous metastases. Clin Exp Metastasis. 2015; 32: 457-65.

6. Locker GY, Hamilton S, Harris J, et al. ASCO 2006 update of recommendations for the use of tumor markers in gastrointestinal cancer. 7 Clin Oncol. 2006; 24: 5313-27.

7. Secco GB, Fardelli R, Gianquinto D, Bonfante P, Baldi E and Campora E. Factors influencing incidence and extension of metachronous liver metastases of colorectal adenocarcinoma. A multivariate analysis. Hepatogastroenterology. 1997; 44: 1057-62.

8. Chuang SC, Su YC, Lu CY, et al. Risk factors for the development of metachronous liver metastasis in colorectal cancer patients after curative resection. World $\mathcal{J}$ Surg. 2011; 35: 424-9.

9. Ganeshan B, Miles KA, Young RC and Chatwin CR. Hepatic entropy and uniformity: additional parameters that can potentially increase the effectiveness of contrast enhancement during abdominal CT. Clinical radiology. 2007; 62: 761-8.

10. Ganeshan B, Miles KA, Young RG and Chatwin CR. Texture analysis in non-contrast enhanced CT: impact of malignancy on texture in apparently disease-free areas of the liver. European journal of radiology. 2009; 70: 101-10.

11. Davnall F, Yip CS, Ljungqvist G, et al. Assessment of tumor heterogeneity: an emerging imaging tool for clinical practice? Insights into imaging. 2012; 3: 573-89.

12. Ganeshan B and Miles KA. Quantifying tumour heterogeneity with CT. Cancer imaging : the official publication of the International Cancer Imaging Society. 2013; 13: 140-9.

13. Chen C, Pau L and Wang P. The Handbook of Pattern Recognition and Computer Vision , 1998. World Scienti. 207-48.

14. Rao SX, Lambregts DM, Schnerr RS, et al. Whole-liver GT texture analysis in colorectal cancer: Does the presence of liver metastases affect the texture of the remaining liver? United European gastroenterology journal. 2014; 2: 530-8.

15. Kruskal JB, Thomas P, Kane RA and Goldberg SN. Hepatic perfusion changes in mice livers with developing colorectal cancer metastases. Radiology. 2004; 231: 48290.

16. Guenod C, Leconte I, Siauve N, et al. Early changes in liver perfusion caused by occult metastases in rats: detection with quantitative CT. Radiology. 2001; 218: 55661.

17. Ganeshan B, Miles KA, Young RG and Chatwin GR. Hepatic enhancement in colorectal cancer: texture analysis correlates with hepatic hemodynamics and patient 
survival. Acad Radiol. 2007; 14: 1520-30.

18. Leen E. The detection of occult liver metastases of colorectal carcinoma. 7 Hepatobiliary Pancreat Surg. 1999; 6: 7-15.

19. Nanko M, Shimada H, Yamaoka H, et al. Micrometastatic colorectal cancer lesions in the liver. Surg Today. 1998; 28: 707-13.

20. Rorden C, Karnath HO and Bonilha L. Improving lesion-symptom mapping. Fournal of cognitive neuroscience. 2007; 19: 1081-8.

21. Rao SX, Lambregts DM, Schnerr RS, et al. CT texture analysis in colorectal liver metastases: A better way than size and volume measurements to assess response to chemotherapy? United European gastroenterology journal. 2016; 4: 257-63.

22. DeLong ER, DeLong DM and Clarke-Pearson DL. Comparing the areas under two or more correlated receiver operating characteristic curves: a nonparametric approach. Biometrics. 1988; 44: 837-45.

23. Bipat S, van Leeuwen MS, Ijzermans JN, Bossuyt PM, Greve JW and Stoker J. Imaging and treatment of patients with colorectal liver metastases in the Netherlands: a survey. The Netherlands journal of medicine. 2006; 64: 147-51.

24. Niekel MC, Bipat S and Stoker J. Diagnostic imaging of colorectal liver metastases with CT, MR imaging, FDG PET, and/or FDG PET/CT: a meta-analysis of prospective studies including patients who have not previously undergone treatment. Radiology. 2010; 257: 674-84.

25. Ganeshan B, Miles KA, Young RG and Chatwin CR. In search of biologic correlates for liver texture on portal-phase CT. Academic radiology. 2007; 14: 1058-68.

26. Bezy-Wendling J, Kretowski M, Rolland Y and Le Bidon W. Toward a better understanding of texture in vascular CT scan simulated images. IEEE transactions on bio-medical engineering. 2001; 48: 120-4.

27. Ganeshan B, Burnand K, Young R, Chatwin C and Miles K. Dynamic contrast-enhanced texture analysis of the liver: initial assessment in colorectal cancer. Invest Radiol. 2011; 46: 160-8.

28. Miles KA, Ganeshan B, Griffiths MR, Young RC and Chatwin CR. Colorectal cancer: texture analysis of portal phase hepatic CT images as a potential marker of survival. Radiology. 2009; 250: 444-52. 


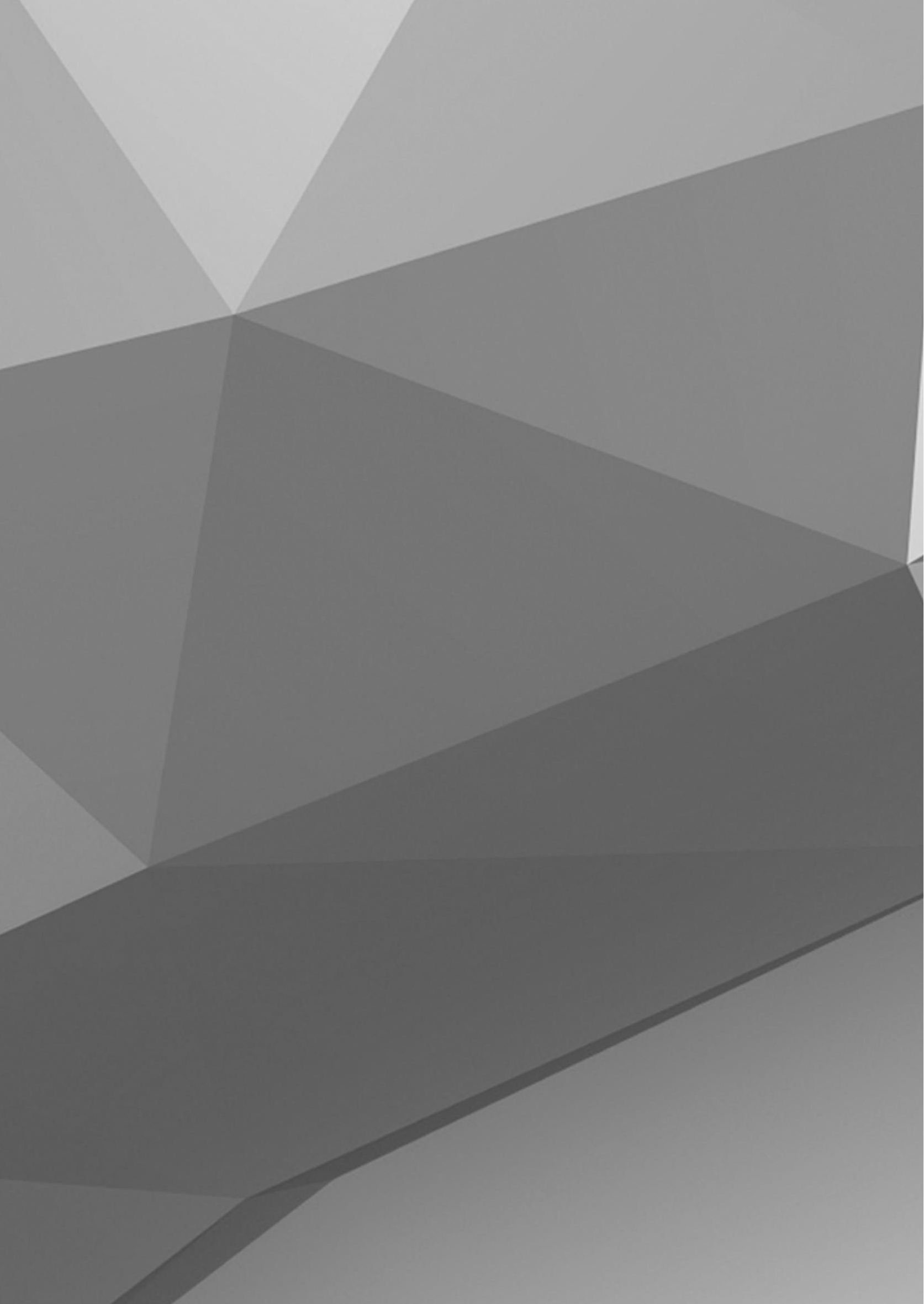





\section{Abstract}

\section{Purpose}

It is unclear whether changes in liver texture in patients with colorectal cancer are caused by diffuse (e.g. perfusional) changes throughout the liver or rather based on focal changes (e.g. presence of occult metastases). The aim of this study is to compare a whole-liver approach to a segmental (Couinaud) approach for measuring the CT texture at the time of primary staging in patients who later develop metachronous metastases and evaluate whether assessing CT texture on a segmental level is of added benefit.

\section{Methods}

46 Patients were included: 27 patients without metastases (follow-up $>2$ years) and 19 patients who developed metachronous metastases within 24 months after diagnosis. Volumes of interest (VOIs) covering the whole liver were drawn on primary staging portal-phase CT. In addition, each liver segment was delineated separately. Mean grey-level intensity, entropy $(\mathrm{E})$ and uniformity $(\mathbf{U})$ were derived with different filters $(\sigma 0.5-2.5)$. Patients/segments without metastases and patients/segments that later developed metachronous metastases were compared using independent samples T-tests.

\section{Results}

Absolute differences in entropy and uniformity between the group without metastases and the group with metachronous metastases group were consistently smaller for the segmental approach compared to the whole-liver approach. No statistically significant differences were found in the texture measurements between both groups.

\section{Conclusions}

In this small patient cohort, we could not demonstrate a clear predictive value to identify patients at risk of developing metachronous metastases within 2 years. Segmental CT-texture analysis of the liver probably has no additional benefit over whole-liver texture analysis. 


\section{Introduction}

With \pm 750.000 new cases every year worldwide, colorectal cancer (CRC) constitutes one of the most common forms of cancer ${ }^{1}$. The most prevalent site of metastases in CRC is the liver (77\%). At time of diagnosis approximately $20 \%$ of patients have metastatic disease $e^{2-5}$. An additional $5 \%$ of patients will develop metachronous metastases within the first year, increasing to $15 \%$ after five years ${ }^{3}$. The exact pathogenesis of the development of colorectal liver metastases is still not fully understood ${ }^{6-8}$. A recent review suggested that there might be a difference in biological characteristics between synchronous and metachronous metastases with synchronous metastases showing a more aggressive disease profile with poorer survival rates ${ }^{9}$. However, other studies reported no difference in survival after resection of liver metastases, whether they appeared synchronously or metachronously ${ }^{10-12}$. A better understanding of the exact pathogenesis of the development of metachronous metastases could be of great influence on clinical practice; knowing which patients are at risk of developing metachronous disease might create opportunities for (neo-) adjuvant treatment and could affect the intensity of follow-up.

Imaging might play a role in this regard. The idea would be that at the early stage of metachronous disease development, changes are already occurring within the liver before any focal liver lesions become apparent. These early changes cannot be observed with common morphological imaging techniques, but may be detected with more sophisticated imaging or post processing techniques. A specific technique that has shown promise is CT texture analysis. Texture analysis is a mathematical approach to quantify the distribution of grey-level values within tissues, thereby providing a measure of tissue heterogeneity ${ }^{13}$. Texture features derived from colorectal liver metastases as well as from the surrounding liver parenchyma have both been reported to correlate with patient survival ${ }^{14,15}$. Moreover, previous reports have shown that differences in the overall liver texture can be observed on CT between patients with and without liver metastases. Similarly, even at the time of primary staging in patients that develop metachronous metastases, texture changes can be observed, particularly in patients who develop metastases early (within 6 months) after diagnosis ${ }^{16,17}$. However, results reported so far are ambiguous and convincing evidence supporting the role of CT texture analysis to predict patients at risk for developing metachronous liver disease has yet to be provided. 
A potential limiting factor could be the methodology of obtaining texture measures. So far, whole liver texture analyses have been performed, based on the assumption that early changes in the liver preceding the manifestation of visible focal liver lesions occur diffusely in the liver parenchyma and are likely to be related to changes in liver perfusion ${ }^{18-20}$. An alternative hypothesis would be that these early changes are more localized to a certain area within the liver (i.e. the specific site where at a later stage the metastases will become visible) and are more related to focal changes on a cellular level (i.e. presence of occult micro metastases) and/or focal perfusional changes ${ }^{14,21}$. In the latter case, a whole liver approach will likely not be sensitive enough to detect these focal changes and a segmental analysis of the liver texture might provide better results.

The aim of this study therefore was to evaluate this hypothesis and get a better insight in the distribution of textural changes within the liver (i.e. diffuse versus focal) by comparing the GT liver texture of patients without metastases and patients with metachronous liver disease using a 'whole liver' versus 'segmental' approach.

\section{Method and materials}

\section{Patients}

This study retrospectively analysed 46 patients who were treated for colorectal cancer at Maastricht Medical Center between August 2009 and November 2013. Informed consent was waived by the local ethical committee. Part of the study patients (44/46) were included in a previously reported multicentre study cohort ${ }^{17}$. As part of their primary staging all patients routinely underwent contrast enhanced abdominal or liver CT. Two groups of patients were defined: (A) the 'no metastases' (control) group, consisting of 27 patients who had no evidence of liver metastases at primary staging, nor during at least 2 years of follow-up and (B) the 'metachronous metastases' group consisting of 19 consecutive patients who had no evidence of liver metastases at primary staging but developed metachronous liver metastases within 24 months after the primary staging. The inclusion criteria consisted of (a) histopathologically confirmed colorectal adenocarcinoma; (b) no extrahepatic metastases; (c) a primary staging CT including a portal venous phase (PVP). Exclusion criteria consisted of (a) previous liver surgery, (b) previous systemic treatment (chemotherapy), (c) diffuse hepatic metastases, leaving no normal segments to compare and $(d)$ evidence of other diffuse liver disease such as steatosis or cirrhosis. 


\section{CT acquisition}

All CT scans included a PVP scan of the liver and were acquired using multi-slice GT equipment (Philips Brilliance 64, Philips Medical Systems, Best, The Netherlands; Siemens Somatom Sensation 16 or Somatom Definition Flash, Siemens Healthcare, Erlangen, Germany). PVP images were obtained with a tube voltage of $120 \mathrm{kVp}$. The contrast medium (Ultravist 300mgI/ml; Iopromide, Bayer Healthcare, Berlin, Germany) was prewarmed to $37^{\circ} \mathrm{C}\left(99^{\circ} \mathrm{F}\right)$ and administered intravenously as a bolus injection of $110 \mathrm{ml}$ at a rate of $3.5 \mathrm{ml} / \mathrm{s}$, followed by a saline flush of $40 \mathrm{ml}$. The scan delay for the PVP was set at $70 \mathrm{sec}$ with a (reconstructed) slice thickness of $5 \mathrm{~mm}$.

\section{Whole-volume versus segmental liver delineation}

All delineations were performed on the initial staging CTs (when all patients were still without any visible colorectal liver metastases). The PVP images were transferred to an offline workstation for liver delineation which was performed using the open source software tool MRIcron ${ }^{22}$. Liver delineation was performed in two ways (Figure 1): (a) whole-liver delineation, and (b) segmental delineation. For the whole-liver delineation a single reader $(\mathrm{RB})$ delineated the whole liver volume (excluding the border of the liver, any visible benign lesions, the inferior vena cava, caudate lobe, large hepatic veins, arteries and biliary vessels) according to methods previously reported ${ }^{16,17}$. For the segmental delineation individual liver segments were delineated, based on Couinaud's classification ${ }^{23}$. Seven segments were included $(2,3,4 \mathrm{ab}, 5,6,7,8)$. The caudate lobe was excluded, since it is often difficult to discern from the border of the vena cava.
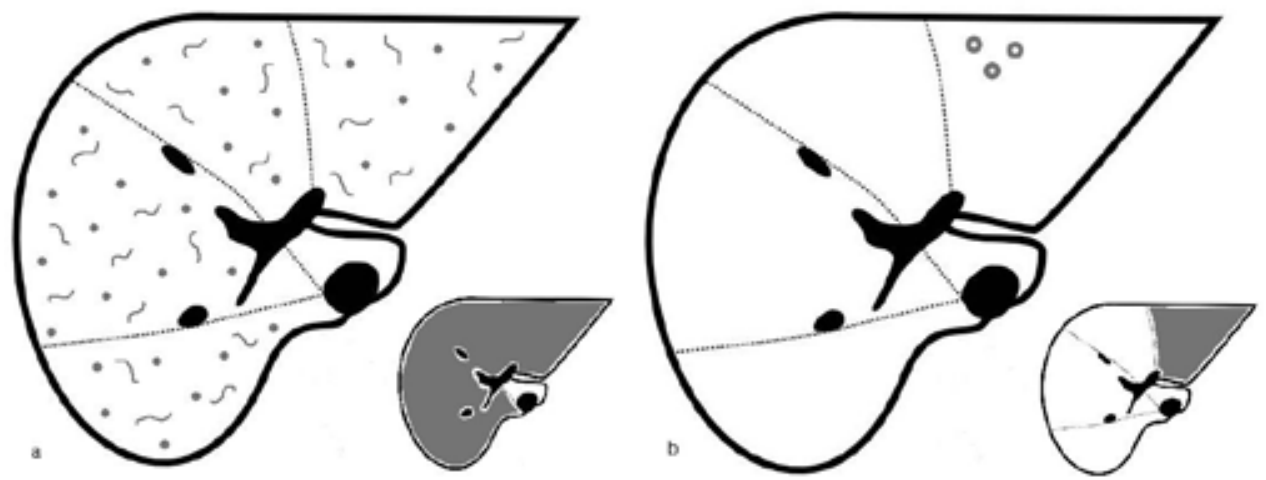

Figure 1. Illustration of the hypothetical concept that textural changes are caused either (a) by changes (e.g. perfusional and/or cellular) occurring diffusely throughout the liver, which can be expected to become most apparent with a whole-volume liver delineation, or (b) by more focally situated changes in the liver caused for example by the presence of occult micrometastases, 


\section{Texture analysis}

2D Texture analysis was performed with a dedicated script written in MATLAB (The MathWorks Inc., Natick, MA, 2000) by one of the authors (RS), according to methods previously reported ${ }^{16,17,24}$. The mathematical analysis technique used for this study comprised two main stages: image filtration followed by the quantification of texture. For image filtration, a Laplacian of Gaussian (LoG) band-pass filter was chosen which was applied in the Fourier space. A reference resolution of $0.84 \mathrm{~mm}$ was chosen and for each CT scan with a different resolution, the width of the LoG-filter $(\sigma)$ was modified to keep the physical size (in $\mathrm{mm}$ ) of the filter constant. A fine $(\sigma=0.5)$, medium $(\sigma=1.5)$ and a coarse filter $(\sigma=2.5)$ were used. For quantification of the texture of the liver parenchyma, mean grey-level intensity $(\mathbf{M})$, entropy $(\mathrm{E})$ and uniformity $(\mathrm{U})$ were used. These features were calculated from a histogram based on the points within the region of interest with a bin size of one Hounsfield unit. $\mathrm{M}$ is the number of bins in the histogram; entropy is based on the width of the histogram and uniformity is based on the narrowness.

\section{Standard of reference}

In the patients without metastases, the absence of metastases was confirmed by means of clinical follow up including regular carcinoembryonic antigen (CEA) level and imaging (CT and in some cases US and/or MRI). The median follow-up time was 54 months (range 35-57 months). In the metachronous metastases group, the presence of metachronous liver lesions was confirmed by histopathology in 10 patients, by growth over time in 5 patients and by corresponding FDG-PET positivity (after initial CT diagnosis) in 4 patients.

\section{Statistical analysis}

Statistical analyses were performed using the Statistical Package for the Social Sciences (IBM Corp. Released 2012. IBM SPSS Statistics for Windows, Version 21.0. Armonk, NY: IBM Corp.) and Stata (StataCorp. 2009. Stata Statistical Software: Release 11. College Station, TX: StataCorp LP). Baseline patient characteristics were assessed and compared using descriptive statistics. Patients/ segments without metastases and with metachronous metastases were compared using independent samples T-test, Mann Whitney U test was used for non-parametric data. For the segmental analysis segments analysed on the initial staging 
CT were matched to segments were disease occurred during follow up. A $P$-value $<0.05$ was considered to indicate statistical significance.

\section{Results}

\section{Patient characteristics}

Of the 46 patients enrolled in the study, 29 patients were male and 17 were female. Median age was 66.5 years (range $44-81$ years). The primary tumour was located in the colon in 24 patients and in the rectum in the other 22 patients. Baseline characteristics of the study patients including results per subgroup are given in Table 1. Nineteen patients developed metachronous metastases with a median diagnosis-metastases interval of 12 months (range 4-20 months). In 1 patient metastases occurred within 6 months, in 9 within 7-12 months and in 9 within 13-24 months. A total of 322 segments were delineated. Of these, 189 segments $(58.7 \%)$ remained without metastases; in 37 segments $(11.5 \%)$ metastases occurred during follow up. Only segments of the patients who remained without metastases were included in the analysis.

\section{Whole liver versus segmental approach}

Table 2 compares the texture values between the no metastases and metachronous metastases group for the whole liver versus the segmental approach. The absolute difference in entropy and uniformity values between the no metastases and metachronous metastases group was consistently smaller for the segmental approach (difference 0.00-0.11 for entropy and 0.13-1.53 for uniformity) compared to the whole volume approach (difference 0.03-0.15 for entropy and 0.702.29 for uniformity). For mean intensity at fine image filtration, the same effect was observed. None of the whole liver nor segmental texture measurements resulted in any statistically significant differences between the no metastases and metachronous metastases group. 
Table 1. Baseline characteristics of the 46 patients

\begin{tabular}{|c|c|c|c|}
\hline \multirow[b]{2}{*}{ Characteristics } & \multicolumn{2}{|l|}{ Group } & \multirow{2}{*}{$\begin{array}{l}\text { Total } \\
(\mathrm{N}=46)\end{array}$} \\
\hline & $\mathrm{A}(\mathrm{N}=27)$ & $\mathrm{B}(\mathrm{N}=19)$ & \\
\hline \multicolumn{4}{|l|}{ Age (y) } \\
\hline Median & 66 & 67 & 66.5 \\
\hline Range & $44-76$ & $47-81$ & $44-81$ \\
\hline \multicolumn{4}{|l|}{ Sex } \\
\hline Male & $17(63)$ & $12(63.2)$ & $29(63)$ \\
\hline Female & $10(37)$ & $7(36.8)$ & $17(37)$ \\
\hline \multicolumn{4}{|l|}{ Primary tumour site } \\
\hline Rectum & $15(55.6)$ & $7(36.8)$ & $22(47.8)$ \\
\hline Colon & $12(44.4)$ & $12(63.2)$ & $24(52.2)$ \\
\hline \multicolumn{4}{|l|}{ Tumour stage * } \\
\hline $\mathrm{T} 1$ & 0 & 0 & 0 \\
\hline $\mathrm{T} 2$ & $7(25.9)$ & 0 & $7(15.2)$ \\
\hline $\mathrm{T} 3$ & $17(63.0)$ & $12(63.2)$ & $29(63.0)$ \\
\hline $\mathrm{T} 4$ & $3(11.1)$ & $7(36.8)$ & $10(21.7)$ \\
\hline \multicolumn{4}{|l|}{ Nodal stage $*$} \\
\hline No & $11(40.7)$ & $3(15.8)$ & $14(30.4)$ \\
\hline N1 & $4(14.8)$ & $6(31.6)$ & $10(21.7)$ \\
\hline $\mathrm{N} 2$ & $12(44.4)$ & $10(52.6)$ & $22(47.8)$ \\
\hline \multicolumn{4}{|l|}{ Histology of primary tumour } \\
\hline Adenocarcinoma n.o.s. & $19(70.4)$ & $14(73.7)$ & $33(71.7)$ \\
\hline Mucinous & $6(22.2)$ & $3(15.8)$ & $9(19.6)$ \\
\hline Signet-ring cell carcinoma & $1(3.7)$ & $2(10.5)$ & $3(6.5)$ \\
\hline Focal neuroendocrine diff. & $1(3.7)$ & 0 & $1(2.1)$ \\
\hline \multicolumn{4}{|l|}{ Time until metastases $(\mathrm{m}) \dagger$} \\
\hline Median & $\mathrm{N} / \mathrm{A}$ & 12 & $\mathrm{~N} / \mathrm{A}$ \\
\hline Range & N/A & $4-20$ & N/A \\
\hline \multicolumn{4}{|c|}{ Carcinoembryonic antigen (CEA) at time of primary diagnosis } \\
\hline $\operatorname{Normal}(<5 \mathrm{mcg} / \mathrm{L})$ & $18(66.7)$ & $9(47.4)$ & $27(58.7)$ \\
\hline Elevated $(\geq 5 \mathrm{mcg} / \mathrm{L})$ & $8(29.6)$ & $8(42.1)$ & $16(34.8)$ \\
\hline
\end{tabular}

Note. - Unless otherwise indicated, data are numbers of patients and data in parentheses are percentages.

Group A: patients without liver metastases;

Group B: patients with metachronous liver metastases within 24 months after primary staging;

N/A: not applicable

* Primary tumour/nodal stage was based on histopathology for patients undergoing direct surgery and based on MRI for patients undergoing neoadjuvant treatment.

$\dagger$ Interval between the primary staging CT and the detection of liver metastases. 


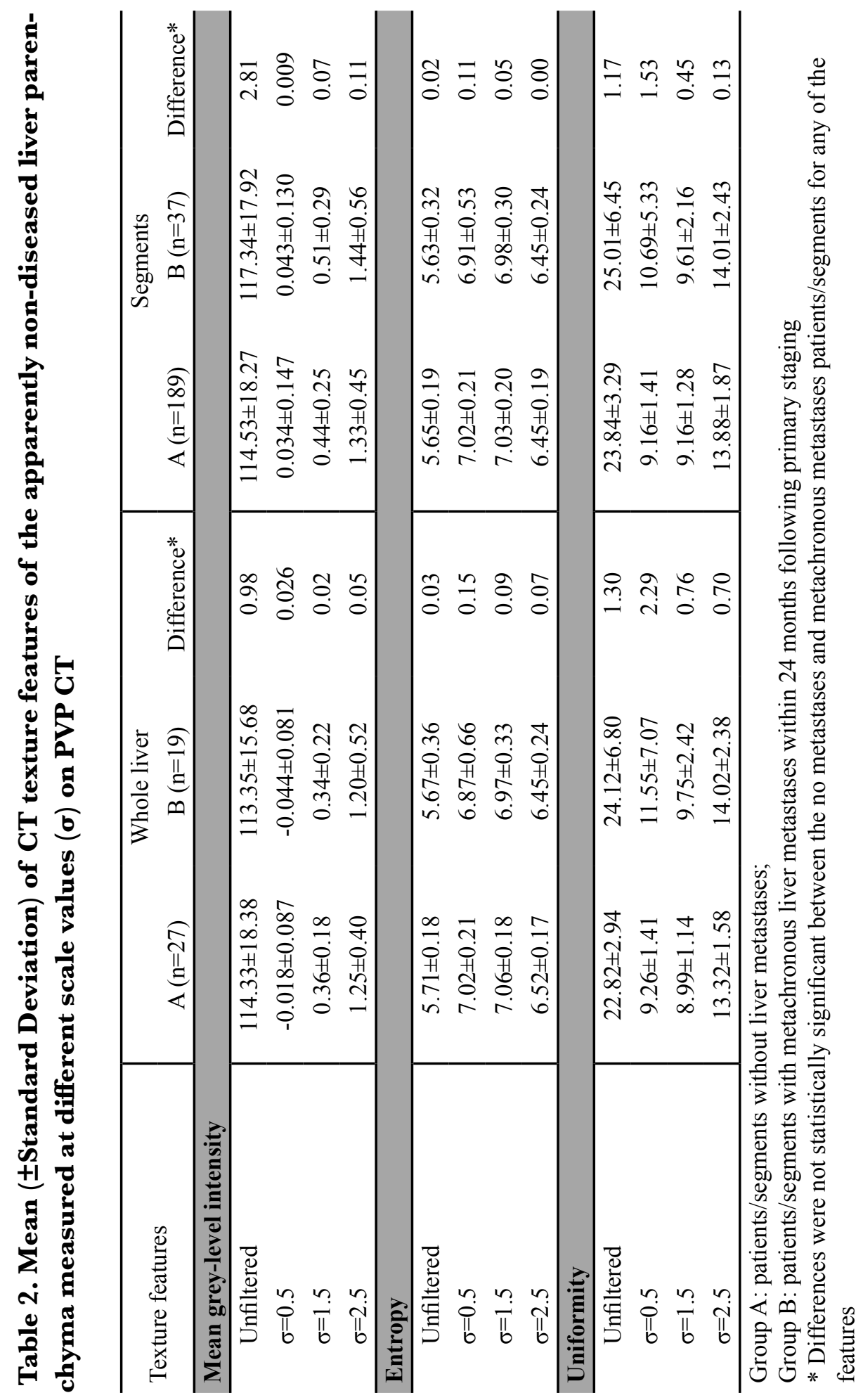




\section{Discussion}

The aim of this study was to get a better insight in the underlying cause of textural changes that can be observed on CT of the liver in patients with colorectal liver metastases. We compared a whole liver approach with a segmental approach using Couinaud's segments to study whether changes in liver texture are most likely caused by focal or diffuse liver pathology. The hypothesis was that in case of occult focal disease (micro metastases) the differences on a segmental level would be more apparent, whereas conversely diffuse changes in liver texture would become more apparent using a whole-liver approach. Although the observed differences are altogether small, our results suggest that differences in texture between patients without metastases and patients who develop metastatic liver $\leq 2$ years after initial diagnosis are more pronounced for the whole-liver approach. However, no additional effect was found for texture measurements on a segmental level.

It has been suggested that diffuse changes in the liver preceding the development of focal liver metastases are probably related to changes in liver perfusion and hepatic hemodynamics ${ }^{14,18}$. Tumour progression towards metastasis is a process with multiple stages in which malignant cells spread from the primary colorectal tumour to colonize the liver ${ }^{25,26}$. Paget's "seed and soil" theory for metastasis states that an adequate microenvironment is required for malignant cells to nest into distant tissues and form metastase ${ }^{27}$. This microenvironment should support malignant cell maintenance and regulate cell function and proliferation so that tumour cells are able to form into clinically detectable metastases ${ }^{28,29}$. One of the key elements in the progression from micro metastasis to visible metastases is the assembly of a functional vascular structure to enable cellular expansion ${ }^{30-32}$. These changes lead to physiological changes such as increased perfusion, blood volume and capillary permeability ${ }^{33}$. It is known that in the liver, tumour angiogenesis occurs when metastases reach approximately $0.5 \mathrm{~mm}$ in size, while lesions can only be visualised with conventional morphological imaging techniques when they reach at least 3-5 $\mathrm{mm}$ in diameter ${ }^{34}$. These observations may explain why changes in the liver texture may already be observed on a whole-liver level (as was reported in previous studies ${ }^{16,17}$ ), while no visible metastases have yet become apparent $t^{35}$. Despite the fact that differences in our study also appeared to be most pronounced for the whole liver approach, we could not confirm a statistically significant difference in texture between patients without metastases and patients who later developed metachronous metastases. A possible contributing factor could be that the median interval between the primary staging CT and the 
development of metastatic lesions in our study was 12 months whereas Beckers et al. previously reported that CT texture was only able to predict metastases occurring early (within 6 months) after primary CRC diagnosis ${ }^{17}$. Our current study cohort was too small to perform meaningful subgroup analyses on the development of early metastases (given that only in 1 patient metastases occurred within 6 months).

Our findings support doubts raised in previous papers with respect to the robustness of texture analysis as a self-contained image quantification method and the current lack of evidence from large-scale prospective studies ${ }^{17}{ }^{36}$. Most likely texture analysis should be used as an adjunct to other parameters, both clinical, laboratory and imaging, with the ultimate aim to develop a comprehensive global clinical prediction model. From the imaging perspective, not only CT texture analysis should be further explored, but also other techniques that have shown promise in previous reports such as diffusion-weighted imaging ${ }^{37}$, perfusion CT and MR imaging ${ }^{38,39}$ and ultrasound Doppler ${ }^{40}$.

There are some limitations to our study. The sample size of patients with metachronous metastases (particularly patients with early metastases) was small. Second, slice thickness in our study was relatively large. Third, image segmentations were only performed by a single reader, although we believe that given the method of whole-liver segmentation and segmentations according to the standardised and well-known Couinaud classification potential effects of interobserver variations can be expected to be limited. Finally, a major limitation is that it is not possible to correlate our findings with underlying histopathological changes in the liver as this would require invasive procedures such as routine liver biopsy, which is not feasible from an ethical perspective. Moreover, in the patients who developed metachronous metastases, histopathological confirmation was only available in 10/19 patients. 


\section{Conclusion}

Our study showed no added value for segmental texture analysis over whole liver CT texture analysis. Despite the lack of pathologic correlation, our results appear to favour the hypothesis that textural changes are more likely based on diffuse, (perfusional) changes, rather than changes occurring on a more focal (segmental) level. Future prospective studies should focus on determining the role of CT texture analysis - as well as other imaging techniques - within the complete spectrum of clinical, laboratory and imaging parameters to develop a clinically meaningful predictive model that can truly impact clinical decision making. 


\section{References}

1. Tanaka S and Imamura Y. International comparisons of cumulative risk of colorectal cancer, from cancer incidence in five continents vol. VIII. Jpn f Clin Oncol. 2006; 36: 186-7.

2. Siegel RL, Miller KD and Jemal A. Cancer statistics, 2015. CA: a cancer journal for clinicians. 2015; 65: 5-29.

3. Manfredi S, Lepage C, Hatem C, Coatmeur O, Faivre J and Bouvier AM. Epidemiology and management of liver metastases from colorectal cancer. Ann Surg. 2006; 244: 254-9.

4. Hess KR, Varadhachary GR, Taylor SH, et al. Metastatic patterns in adenocarcinoma. Cancer. 2006; 106: 1624-33.

5. Landreau P, Drouillard A, Launoy G, et al. Incidence and survival in late liver metastases of colorectal cancer. Fournal of gastroenterology and hepatology. 2015; 30: 82-5.

6. Rudmik LR and Magliocco AM. Molecular mechanisms of hepatic metastasis in colorectal cancer. Fournal of surgical oncology. 2005; 92: 347-59.

7. Wang SC, Lin JK, Wang HS, Yang SH, Li AF and Chang SC. Nuclear expression of CXGR4 is associated with advanced colorectal cancer. Int $\mathcal{J}$ Colorectal Dis. 2010; 25: 1185-91.

8. Slesser AA, Georgiou P, Brown G, Mudan S, Goldin R and Tekkis P. The tumour biology of synchronous and metachronous colorectal liver metastases: a systematic review. Clin Exp Metastasis. 2013; 30: 457-70.

9. Tan EK and Ooi LL. Colorectal cancer liver metastases - understanding the differences in the management of synchronous and metachronous disease. Ann Acad Med Singapore. 2010; 39: 719-15.

10. Li ZQ, Liu K, Duan JC, Li Z, Su CQ and YangJH. Meta-analysis of simultaneous versus staged resection for synchronous colorectal liver metastases. Hepatol Res. 2013; 43: 72-83.

11. Yin Z, Liu C, Chen Y, et al. Timing of hepatectomy in resectable synchronous colorectal liver metastases (SCRLM): Simultaneous or delayed? Hepatology. 2013; 57: 2346-57.

12. Slesser AA, Simillis C, Goldin R, Brown G, Mudan S and Tekkis PP. A meta-analysis comparing simultaneous versus delayed resections in patients with synchronous colorectal liver metastases. Surg Oncol. 2013; 22: 36-47.

13. Castellano G, Bonilha L, Li LM and Cendes F. Texture analysis of medical images. Clinical radiology. 2004; 59: 1061-9.

14. Ganeshan B, Miles KA, Young RG and Chatwin CR. Hepatic enhancement in colorectal cancer: texture analysis correlates with hepatic hemodynamics and patient survival. Academic radiology. 2007; 14: 1520-30.

15. Lubner MG, Stabo N, Lubner SJ, et al. GT textural analysis of hepatic metastatic colorectal cancer: pre-treatment tumor heterogeneity correlates with pathology and clinical outcomes. Abdominal imaging. 2015; 40: 2331-7.

16. Rao SX, Lambregts DM, Schnerr RS, et al. Whole-liver CT texture analysis in colorectal cancer: Does the presence of liver metastases affect the texture of the remaining liver? United European gastroenterology journal. 2014; 2: 530-8.

17. Beckers RCJ, Lambregts DMJ, Schnerr RS, et al. Whole liver CT texture analysis to 
predict the development of colorectal liver metastases - A multicentre study. European journal of radiology. 2017; 92: 64-71.

18. Ganeshan B, Miles KA, Young RG and Chatwin CR. In search of biologic correlates for liver texture on portal-phase CT. Academic radiology. 2007; 14: 1058-68.

19. Leen E. The detection of occult liver metastases of colorectal carcinoma. 7 Hepatobiliary Pancreat Surg. 1999; 6: 7-15.

20. Kruskal JB, Thomas P, Kane RA and Goldberg SN. Hepatic perfusion changes in mice livers with developing colorectal cancer metastases. Radiology. 2004; 231: 48290.

21. Guenod C, Leconte I, Siauve N, et al. Early changes in liver perfusion caused by occult metastases in rats: detection with quantitative CT. Radiology. 2001; 218: 556-61.

22. Rorden C, Karnath HO and Bonilha L. Improving lesion-symptom mapping. Fournal of cognitive neuroscience. 2007; 19: 1081-8.

23. Couinaud C. Le foie: études anatomiques et chirurgicales.: Masson \& Cie, 1957.

24. Rao SX, Lambregts DM, Schnerr RS, et al. CT texture analysis in colorectal liver metastases: A better way than size and volume measurements to assess response to chemotherapy? United European gastroenterology journal. 2016; 4: 257-63.

25. Gupta GP and Massague J. Cancer metastasis: building a framework. Cell. 2006; 127: 679-95.

26. Weinberg R. The biology of cancer. Garland science, 2013.

27. Paget $\mathrm{S}$. The distribution of secondary growths in cancer of the breast. 1889. Cancer Metastasis Rev. 1989; 8: 98-101.

28. Kaplan RN, Riba RD, Zacharoulis S, et al. VEGFR1-positive haematopoietic bone marrow progenitors initiate the pre-metastatic niche. Nature. 2005; 438: 820-7.

29. Eveno C, Hainaud P, Rampanou A, et al. Proof of prometastatic niche induction by hepatic stellate cells. 7 Surg Res. 2015; 194: 496-504.

30. Holmgren L, O'Reilly MS and Folkman J. Dormancy of micrometastases: balanced proliferation and apoptosis in the presence of angiogenesis suppression. Nat Med. 1995; 1: 149-53.

31. Naumov GN, Akslen LA and Folkman J. Role of angiogenesis in human tumor dormancy: animal models of the angiogenic switch. Cell Cycle. 2006; 5: 1779-87.

32. Hicklin DJ and Ellis LM. Role of the vascular endothelial growth factor pathway in tumor growth and angiogenesis. 7 Clin Oncol. 2005; 23: 1011-27.

33. Miles KA, Leggett DA, Kelley BB, Hayball MP, Sinnatamby R and Bunce I. In vivo assessment of neovascularization of liver metastases using perfusion CT. Br $\mathcal{F}$ Radiol. 1998; 71: 276-81.

34. Archer SG and Gray BN. Vascularization of small liver metastases. Br $\mathcal{J}$ Surg. 1989; 76: 545-8.

35. Allison KH, Fligner CL and Parks WT. Radiographically occult, diffuse intrasinusoidal hepatic metastases from primary breast carcinomas: a clinicopathologic study of 3 autopsy cases. Arch Pathol Lab Med. 2004; 128: 1418-23.

36. Chalkidou A, O'Doherty MJ and Marsden PK. False Discovery Rates in PET and CT Studies with Texture Features: A Systematic Review. PLoS One. 2015; 10: e0124165.

37. Lambregts DM, Martens MH, Quah RC, et al. Whole-liver diffusion-weighted MRI histogram analysis: effect of the presence of colorectal hepatic metastases on the remaining liver parenchyma. Eur $\mathcal{f}$ Gastroenterol Hepatol. 2015; 27: 399-404. 
38. Tsushima Y, Blomley MJ, Yokoyama H, Kusano S and Endo K. Does the presence of distant and local malignancy alter parenchymal perfusion in apparently disease-free areas of the liver? Digestive diseases and sciences. 2001; 46: 2113-9.

39. White MJ, O'Gorman RL, Charles-Edwards EM, et al. Parametric mapping of the hepatic perfusion index with gadolinium-enhanced volumetric MRI. Br $\mathcal{F}$ Radiol. 2007; 80: 113-20.

40. Kopljar M, Patrlj L, Busic Z, et al. Potential use of Doppler perfusion index in detection of occult liver metastases from colorectal cancer. Hepatobiliary Surg Nutr. 2014; 3: 259-67. 

5. GT texture analysis in colorectal liver metastases and the surrounding liver parenchyma and its potential as an imaging biomarker of disease aggressiveness, response and survival

Rianne C.J. Beckers, Stefano Trebeschi, Monique Maas, Roald S. Schnerr, Julie M.L. Sijmons, Geerard L. Beets, Janneke B. Houwers, Regina G.H. Beets-Tan, Doenja M.J Lambregts

Published in:

European Journal of Radiology. 2018 May; 102:15-21 


\section{Abstract}

\section{Objectives}

To study the ratio between the CT texture of colorectal liver metastases (CRLM) and the surrounding liver parenchyma and assess the potential of various texture measures and ratios as predictive/prognostic imaging markers.

\section{Materials}

Seventy patients with colorectal cancer and synchronous CRLM were included. All visible metastases, as well as the whole-volume of the surrounding liver, were separately delineated on the portal venous phase primary staging CT. Texture features entropy $(\mathrm{E})$ and uniformity $(\mathrm{U})$ were extracted and ratios between the texture features $(\mathrm{T})$ of the metastases and background liver $\left(\mathrm{T}_{\text {metastases }} / \mathrm{T}_{\text {liver }}\right)$ calculated. Texture features were compared with clinical outcome parameters: [1] extent of disease (i.e. number of metastases), [2] response to chemotherapy (in 56/70 patients who underwent chemotherapy and CT for response evaluation), and [3] overall survival.

Results

The $\mathrm{E}_{\text {metastases }} / \mathrm{E}_{\text {liver }}$ ratio was lower in patients with limited disease $(P=0.02)$ and associated with overall survival, albeit not statistically significant when tested in multivariable analyses (HR 1.90; $P=0.07) ; \mathrm{U}_{\text {metastases }} / \mathrm{U}_{\text {liver }}$ was higher in patients with limited disease $(P=0.02) . \mathrm{E}_{\text {metastases }}$ showed a trend towards a higher value in patients that responded well to chemotherapy $(P=0.08)$.

\section{Conclusion}

The ratio between the texture of liver metastases and the surrounding liver appears to reflect relevant changes in tissue microarchitecture and may be of value to assess the extent of disease and help predict overall survival. 


\section{Introduction}

Colorectal cancer is one of the most common cancers worldwide ${ }^{1}$. Approximately $15-25 \%$ of all patients have colorectal liver metastases (CRLM) at the time of diagnosis ${ }^{2-4}$. These synchronous CRLM patients tend to have a poor prognosis with a reported 1-year survival of less than $30 \%$ and a 5 -year survival of less than $5 \%$ when untreated, with 5 -year survival rates of up to $60 \%$ in selected groups that can undergo curative surgical resection ${ }^{3}$.

Imaging plays a crucial role in the diagnosis and follow-up of CRLM. In many institutions, contrast-enhanced CT remains the primary modality for the staging of patients with colorectal cancer ${ }^{5}$, although MRI is increasingly applied because of its superiority in detecting small liver metastases ${ }^{6}$. To date, the mainstay of imaging assessment consists of a visual assessment of lesions and changes in size and morphology as a result of the response to therapy. The most widely adopted method to evaluate treatment response is Response Evaluation Criteria in Solid Tumours (RECIST), which provides standardised measures of response in terms of lesion size ${ }^{7}$. Although commonly used in clinical trials and daily practice, RECIST is known to have significant limitations as size measurements fail to capture (micro-)structural changes related to for example intralesional perfusional or necrotic changes, which are known to be significant factors associated with therapeutic response ${ }^{7-9}$.

Therefore, there is nowadays a growing interest in the use of quantitative imaging and image post-processing techniques to gain a more profound insight into the tumour biology. One of such techniques is texture analysis, which is a mathematical approach that uses an algorithm to quantify tissue heterogeneity by assessing the distribution of coarseness and irregularity of pixel intensities within a volume of interest (VOI) derived from a lesion or organ on an image ${ }^{10}$. In patients with CRLM, texture analysis has been studied using both CT and MRI data, although most evidence so far exists for CT. So far, two main settings have been explored: one group of studies focused on the intralesional texture of the liver metastases itself, which was found to significantly correlate with the response to chemotherapy, as well as with survival ${ }^{11-14}$. Other studies focused not on the texture of the metastases, but on that of the surrounding apparently disease free liver parenchyma and showed that diffuse parenchymal textural changes may hold promise as a prognostic marker to assess and even predict the occurrence of metastatic disease in the liver ${ }^{15,16}$. Although the texture of both liver metastases and surrounding liver have been studied, to our knowledge there have been no 
reports so far studying the relation between the two. This would be worthwhile to study as it may potentially provide valuable insights into the relation between texture findings and underlying tumour behaviour.

The aim of our study is twofold: first, we aim to explore the relation between the GT texture of CRLM and the surrounding liver parenchyma and assess if the ratio between the two may be of added value as a predictive or prognostic imaging marker. Second, we want to investigate whether we can confirm results of previous studies that CT texture analysis has a potential value as a biomarker of disease aggressiveness, response and survival in patients with CRLM.

\section{Materials and Methods}

\section{Patients}

Eighty-three consecutive patients with GRLM treated at Maastricht University Medical Center between April 2008 and December 2013 were considered for inclusion in this retrospective study. The study was approved by the institutional ethical review board; due to the retrospective nature, informed consent was not required. Inclusion criteria were as follows: (a) histopathologically confirmed primary (non-recurrent) colorectal adenocarcinoma; (b) availability of a primary staging CT including (at least) a portal venous phase (PVP); (c) presence of at least one synchronous CRLM at the time of diagnosis and staging; (d) no previous liver surgery; (e) no previous chemotherapy and (f) no clinical or imaging evidence of diffuse liver diseases such as steatosis or cirrhosis. Thirteen patients were excluded because of the presence of concomitant second malignancies at the time of diagnosis $(n=3)$, inadequate CT contrast timing $(n=3)$, and the presence of diffuse hepatic metastases, leaving too little 'normal' liver parenchyma to delineate $(n=7)$. This left a total study population of 70 patients (50 male/20 female, median age 69, range 39-85) for inclusion; see consort diagram in Figure 1. Part of the study patients (29/70) were included in a previously published multicentre study cohort, which focussed on whole liver texture analysis to predict metachronous CRLM and therefore does not overlap with the aims of the current study ${ }^{15}$. 


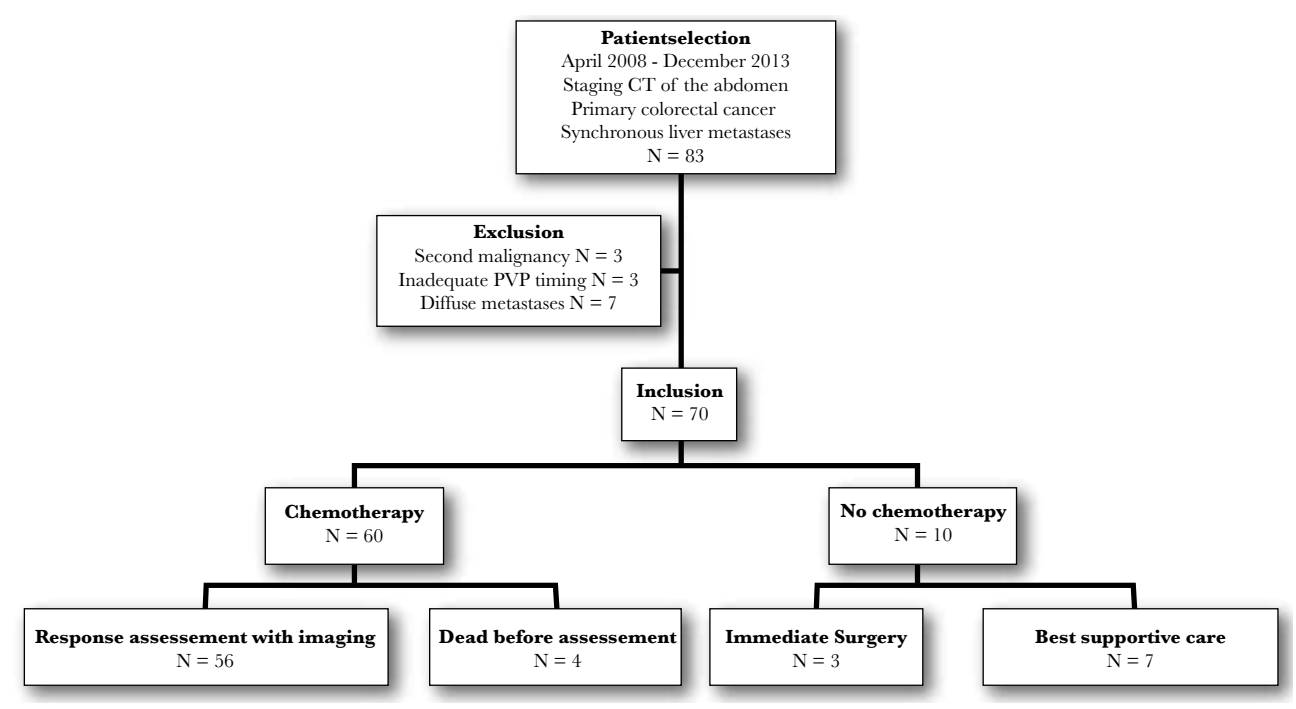

Figure 1. Flow-chart of the selection, inclusion and treatment of the studied patients

\section{CT acquisition}

All CT scans were acquired using multi-slice CT equipment (Philips Brilliance 64, Philips Medical Systems, Best, The Netherlands; Siemens Somatom Sensation 16 or Somatom Definition Flash, Siemens Healthcare, Erlangen, Germany). PVP images of the liver/abdomen were obtained with a tube voltage of 100-120 $\mathrm{kVp}$. The contrast medium (Ultravist $300 \mathrm{mgI} / \mathrm{ml}$; Iopromide, Bayer Healthcare, Berlin, Germany) was prewarmed to $37^{\circ} \mathrm{C}\left(99^{\circ} \mathrm{F}\right)$ and administered intravenously as a bolus injection of $110 \mathrm{ml}$ at a rate of $3.5 \mathrm{ml} / \mathrm{s}$, followed by a saline flush of $40 \mathrm{ml}$. The scan delay for the PVP was set at 70 secs. Images were reconstructed in transverse plane using iterative reconstruction (Siemens Somatom Definition Flash) or filtered backprojection (Philips Brilliance 64 / Siemens Somatom Sensation 16) with a soft tissue filter. Slice thickness was 3 or $5 \mathrm{~mm}$.

\section{Image delineation}

All delineations were performed on the primary staging CT. The PVP images were transferred to an offline workstation for delineation, using an open source software tool (MANGO; Multi-image Analysis GUI, version 2.6, Research Imaging Institute, University of Texas Health Science Genter, San Antonio, TX). One reader with experience in liver delineation $(\mathrm{RB})$ manually delineated per slice (a) all visible liver metastases, and (b) the surrounding (apparently disease free) liver parenchyma (Figure 2). Delineations were performed according to methods pre- 
viously reported ${ }^{13,15,16}$. For the delineation of the surrounding liver, the border of the liver, any visible focal liver lesions (including both benign lesions as well as any metastases), the inferior vena cava, caudate lobe, large hepatic veins, arteries and biliary ducts were excluded from the VOI.

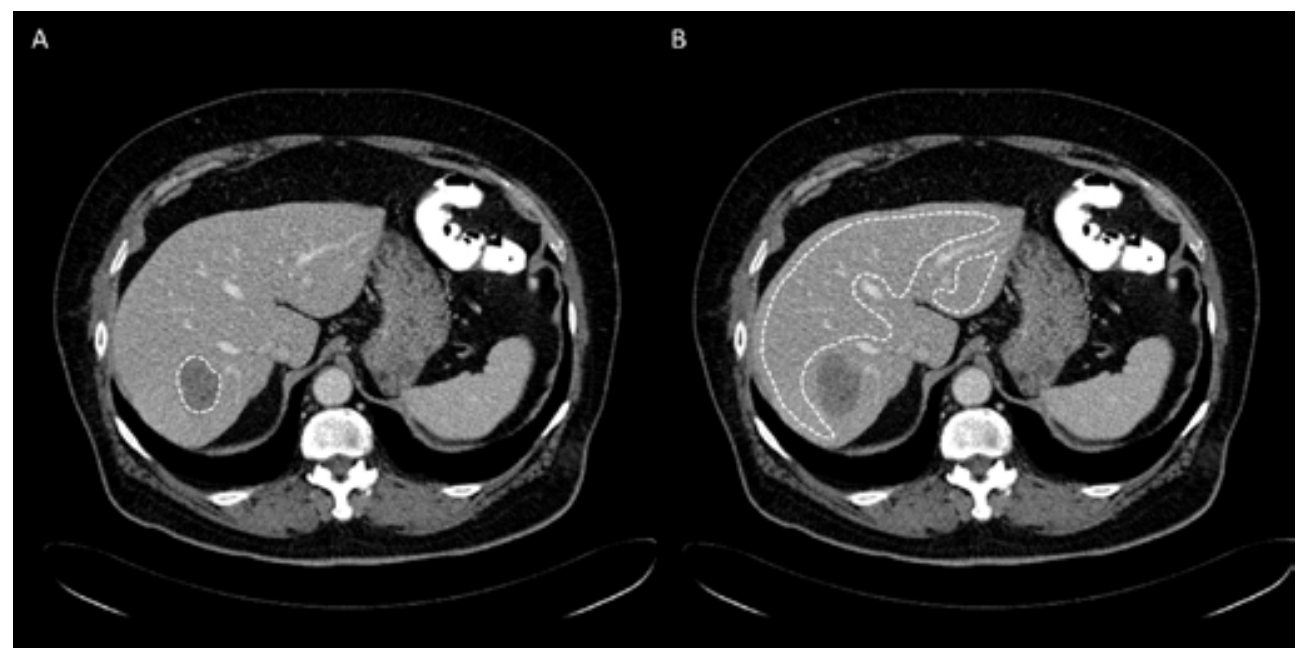

Figure 2. Representative example of the initial staging portal venous phase CT image of a patient with a solitary CRLM. The dotted lines represent the delineations used to derive the texture features. (A) shows the delineation of the metastasis, while (B) shows the delineation of the background liver. The border of the liver, any visible lesions, the inferior vena cava and large portal and hepatic veins were excluded. The ratio of the texture features $(T)$ between the metastases and background liver were calculated as $T_{\text {metastases }} / T_{\text {liver }}$

\section{Texture analysis}

2D Texture analysis was performed with an in-house software written in Python (Python Software Foundation, version 2.7, http://www.python.org) by one of the authors (ST; who was blinded to all clinical patient data and outcomes) largely based on the open source Python package pyradiomics ${ }^{17}$, according to methods previously reported ${ }^{13,15,16}$. The image analysis technique used for this study comprised two main stages: image filtration followed by the quantification of texture. Prior to feature extraction, GT volumes were resampled to isotropy ( $1 \mathrm{x} 1 \mathrm{x} 1 \mathrm{~mm})$ using b-spline basis functions, whereas nearest neighbour was used for the delineations. In addition to the original image, the Laplacian of Gaussian (LoG) filter was applied to enhance edges and irregularities at two different resolutions: fine $(\sigma=0.5)$ and coarse $(\sigma=2.5)$. For quantification of the texture, entropy $(\mathrm{E})$ and uni- 
formity $(\mathbf{U})$ were the main parameters that were extracted, similar to previously reported research on texture analysis in CRLM ${ }^{18}$. The meaning of these two features in relation to tissue microarchitecture is schematically illustrated in Figure 3. Entropy is a measure that gives an indication of the irregularity of the grey-level distribution, while conversely, the uniformity is indicative of its homogeneity. A higher entropy (and low uniformity) typically reflects a more "heterogeneous" distribution of pixels (and thus a more heterogeneous underlying tissue structure) while on the other hand a high uniformity is associated with a more "homogeneous" distribution of pixels (and therefore a more homogeneous tissue structure) ${ }^{19-21}$. Both features were calculated from a histogram, based on the points within the region of interest with a bin size of one Hounsfield unit. For each texture feature the ratio between the metastases and surrounding liver was calculated according to the following formula:

$\mathrm{T}$ represents the respective texture features, $\mathrm{T}_{\text {metastases }}$ represents the VOIs of all visible liver metastases combined for each patient, and $\mathrm{T}_{\text {liver }}$ represents the VOI of the whole volume of the surrounding liver (excluding the metastases). Total time required to delineate and analyse one patient case was approximately 15 minutes. 


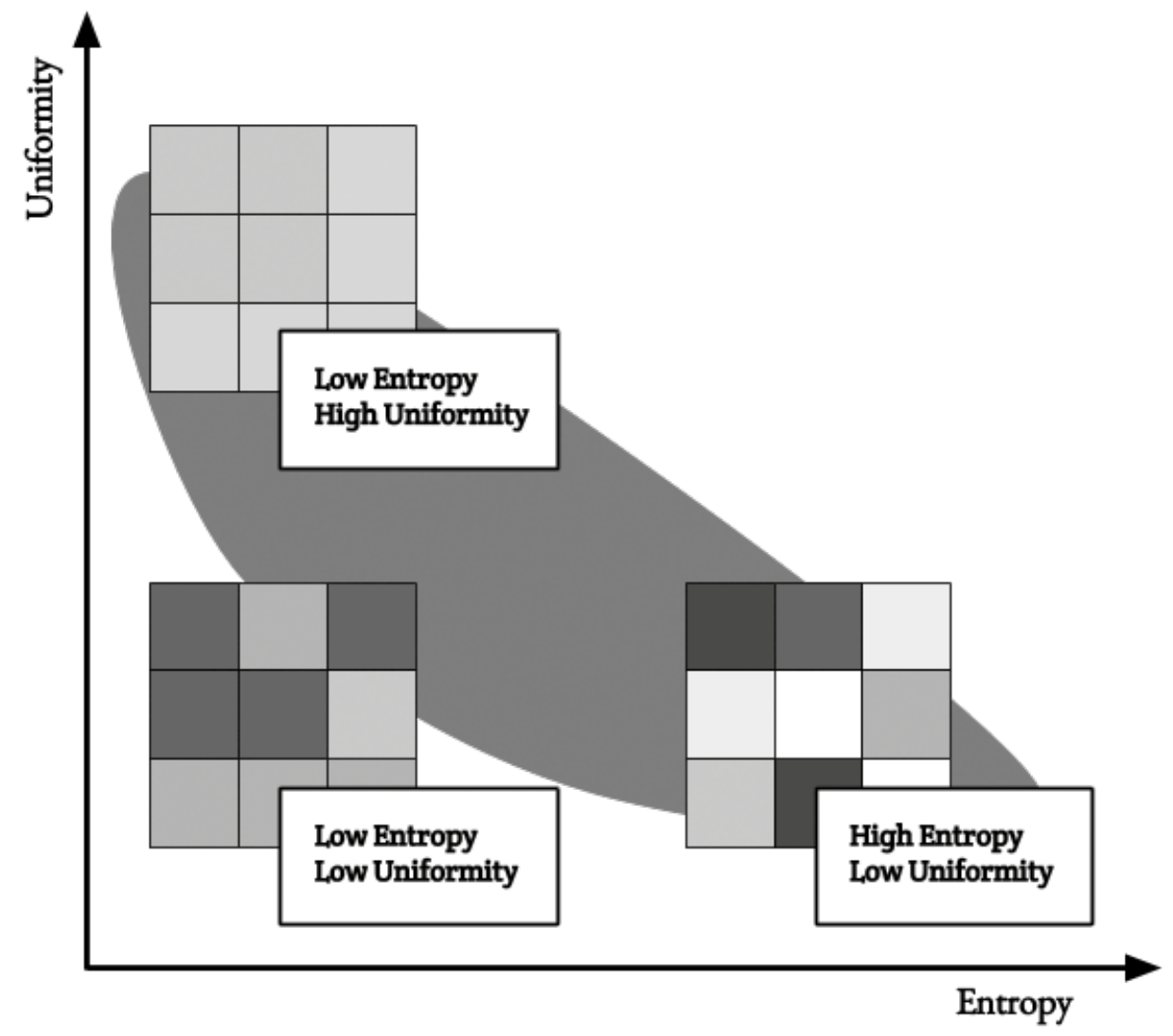

Figure 3. Illustration of the relationship between entropy (E) and uniformity $(U)$ values. Low values of entropy and uniformity are shown in the bottom left with randvom displacement of few intensity values. As the image becomes more hypo-intense, with only few spots of hyper-intensity, the uniformity increases (upper left) while the entropy remains unaffected. On the other hand, allowing for a range of hyper-intensities which will induce a more irregular, unpredictable pattern (bottom right) the entropy will increase, as the distribution becomes more uncertain.

\section{Clinical outcome measures/standard of reference}

Texture features were compared with three clinical outcome parameters: (1) extent of disease, (2) response to chemotherapy, and (3) overall survival (OS). For the extent of disease, patients were categorised based on the number of liver metastases visible at the time of diagnosis: patients with $\geq 5$ liver metastases were classified as the 'extensive disease' group and patients with $<5$ liver metastases as the 'limited disease' group (a cut-off based on previous literature) ${ }^{22}$. Since not all patients underwent surgical resection of their liver metastases, response to 
chemotherapy was assessed on post-chemotherapy imaging and patients were categorized according to RECIST $1.1^{7}$. Patients with complete response (CR) or partial response (PR) were classified as the 'responders' group and patients with stable disease (SD) or progressive disease (PD) were classified as the 'nonresponders' group. OS was defined as the absence of death during follow-up. Fifty-eight patients died during follow-up, median FU in these patients was 14.5 months (range 1-71). In the twelve patients that were still alive at the time of writing, median FU was 57.5 months (rang 43-103).

\section{Statistical analysis}

Statistical analyses were performed using the Statistical Package for the Social Sciences (IBM Corp. Released 2015. IBM SPSS Statistics for Windows, Version 23.0. Armonk, NY: IBM Corp.). The Shapiro-Wilk Test was used to test for normality. Independent sample T-tests (or Mann-Whitney U test in case of non-normally distributed data) were used to compare mean texture features and ratios between (a) patients with limited ( $<5$ liver metastases) versus extensive $(\geq 5$ metastases) disease and (b) responders versus nonresponders (according to RECIST 1.1). The Holm-Bonferroni correction method was used to correct for multiple testing ${ }^{23}$.

The predictive value of texture parameters for OS was assessed by use of multivariable Cox proportional hazards models. With univariable analyses, the potentially predictive factors were identified, which were then entered in the multivariable Cox proportional hazards model. Hazard ratios (HRs) with 95\% confidence intervals $(\mathrm{CI})$ were calculated. $P$-values $\leq 0.05$ were considered statistically significant.

\section{Results}

\section{Patients}

Baseline patient characteristics are described in Table 1. The primary tumor site was the rectum in 30 and the colon in 40 patients. The median number of CRLMs per patient was 3 (range 1-20); 42 patients had $<5$ metastases (limited disease) and 28 had $\geq 5$ metastases (extensive disease). Three patients underwent immediate surgical resection. Sixty patients underwent neoadjuvant or palliative chemotherapy; the routine neoadjuvant chemotherapeutic regimen (in 80\% of patients) consisted of CAPOX with or without the addition of Bevacizumab. In the patients undergoing chemotherapy, response evaluation with imaging (according to 
RECIST 1.1) was available in 56 patients: 31 were responders (all PR), 25 were nonresponders (17 SD, 8 PD). Median OS was 22,5 months (range 1-102 months).

\section{Table 1. Baseline characteristics}

\begin{tabular}{|c|c|}
\hline Patient characteristics & Total $N=70$ \\
\hline \multicolumn{2}{|l|}{ Age (y) } \\
\hline Median & 69 \\
\hline Range & $39-85$ \\
\hline \multicolumn{2}{|l|}{ Sex } \\
\hline Male & $50(71.4)$ \\
\hline Female & $20(28.6)$ \\
\hline \multicolumn{2}{|l|}{ Primary tumor site } \\
\hline Rectum & $30(42.9)$ \\
\hline Colon & $40(57.1)$ \\
\hline \multicolumn{2}{|l|}{ Number of hepatic metastases } \\
\hline Median & 3 \\
\hline Range & $1-20$ \\
\hline \multicolumn{2}{|l|}{ Extrahepatic metastases } \\
\hline No & $36(51.4)$ \\
\hline Yes & $34(48.6)$ \\
\hline Intra-abdominal only & $7(10)$ \\
\hline $\begin{array}{l}\text { Extra-abdominal } \\
(+/- \text { intra abdominal })\end{array}$ & $27(38.6)$ \\
\hline \multicolumn{2}{|l|}{ Treatment CRLM } \\
\hline Immediate surgery & $3(4.3)$ \\
\hline Chemotherapy \& surgery & $22(31.4)$ \\
\hline Palliative chemotherapy & $38(54.3)$ \\
\hline Best supportive care & $7(10.0)$ \\
\hline \multicolumn{2}{|l|}{ Chemotherapy regimen } \\
\hline CAPOX* + Bevacizumab & $39(65.0)$ \\
\hline CAPOX* & $9(15.0)$ \\
\hline Capecitabine & $7(11.7)$ \\
\hline Other & $5(8.3)$ \\
\hline
\end{tabular}

Note. - Unless otherwise indicated, data are numbers of patients and data in parentheses are percentages.

* CAPOX: capecitabine + oxaliplatin 
Texture features to assess limited vs. extensive disease

Table 2 compares the texture features and ratios of patients with limited $(<5$ lesions) and extensive ( $\geq 5$ lesions) disease. The ratio for the entropy without filter $\left(\mathrm{E}_{\text {metastases }} / \mathrm{E}_{\text {liver }}\right)$ was significantly lower in patients with limited disease $(P=0.02)$ while correspondingly the ratio for uniformity $\left(\mathrm{U}_{\text {metastases }} / \mathrm{U}_{\text {liver }}\right)$ was significantly higher $(P=0.02)$. The remaining ratios, as well as the separate texture features $(\mathrm{E}$ and $\mathrm{U})$ of the metastases and liver itself, did not show statistically significant differences between the two groups $(P=0.67-1.00)$.

Texture features to assess response vs. nonresponse (RECIST 1.1)

Table 2 compares the texture features and ratios between responders and nonresponders for the 56 patients for whom a RECIST response assessment after neoadjuvant chemotherapy was available. Only the lesion entropy without filter $\left(\mathrm{E}_{\text {metastases }}\right)$ showed a trend towards a higher value in responders $(P=0.08)$. None of the other features or ratios resulted in any significant outcomes $(P=0.48-1.00)$.

\section{Texture features to predict survival}

Table 3 shows the results for the univariable analyses. Based on these results, the $\mathrm{E}_{\text {metastases }} / \mathrm{E}_{\text {liver }}$ ratio (without filter) was combined with age at diagnosis, chemotherapy $(\mathrm{Y} / \mathrm{N})$, number of CRLM, resection of CRLM $(\mathrm{Y} / \mathrm{N})$ and the presence of extrahepatic metastases (none/abdominal only/extra-abdominal metastases) in the multivariable model, the results of which are presented in Table 4.

The $\mathrm{E}_{\text {metastases }} / \mathrm{E}_{\text {liver }}$ showed a trend towards significance in the multivariable model with a HR of $1.90(0.95-3.78 ; P=0.07)$. Resection of CRLM was an independent predictor of OS (HR 0.26; CI $0.11-0.60 ; P=0.004)$, as was chemotherapy (HR 0.42; CI 0.18-0.98; $P=0.04$ ). 
Table 2. Textural features of patients with $<5$ or $\geq 5$ lesions and responders and nonresponders according to RECIST 1.1

\begin{tabular}{|c|c|c|c|c|c|c|}
\hline & $\begin{array}{c}<5 \text { Lesions } \\
\mathrm{N}=42\end{array}$ & $\begin{array}{c}\geq 5 \text { Lesions } \\
\quad N=28\end{array}$ & $P^{*}$ & $\begin{array}{c}\text { Responders } \\
\mathbf{N}=\mathbf{3 1}\end{array}$ & $\begin{array}{c}\text { Nonre- } \\
\text { sponders } \\
\mathbf{N}=\mathbf{2 5}\end{array}$ & $\boldsymbol{P}^{*}$ \\
\hline \multicolumn{7}{|l|}{ Without filter } \\
\hline $\mathrm{E}_{\text {liver }}$ & $6.37 \pm 0.24$ & $6.29 \pm 0.25$ & 1.00 & $6.32 \pm 0.26$ & $6.34 \pm 0.25$ & 1.00 \\
\hline $\mathrm{U}_{\text {liver }}$ & $0.02 \pm 0.003$ & $0.02 \pm 0.003$ & 1.00 & $0.02 \pm 0.003$ & $0.02 \pm 0.002$ & 1.00 \\
\hline $\mathrm{E}_{\text {metastases }}$ & $6.57 \pm 0.33$ & $6.71 \pm 0.24$ & 0.67 & $6.65 \pm 0.26$ & $6.51 \pm 0.34$ & 0.08 \\
\hline $\mathrm{U}_{\text {metastases }}$ & $0.01 \pm 0.003$ & $0.01 \pm 0.002$ & 0.94 & $0.01 \pm 0.002$ & $0.01 \pm 0.003$ & 1.00 \\
\hline $\mathrm{E}_{\text {metastases }} / \mathrm{E}_{\text {liver }}$ & $1.03 \pm 0.05$ & $1.07 \pm 0.03$ & 0.02 & $1.05 \pm 0.03$ & $1.03 \pm 0.06$ & 0.59 \\
\hline $\mathrm{U}_{\text {metastases }} / \mathrm{U}_{\text {liver }}$ & $0.87 \pm 0.21$ & $0.74 \pm 0.09$ & 0.02 & $0.78 \pm 0.11$ & $0.89 \pm 0.26$ & 0.48 \\
\hline \multicolumn{7}{|l|}{ Fine filter } \\
\hline $\mathrm{E}_{\text {liver }}$ & $5.15 \pm 0.25$ & $5.08 \pm 0.25$ & 1.00 & $5.10 \pm 0.27$ & $5.12 \pm 0.25$ & 1.00 \\
\hline $\mathrm{U}_{\text {liver }}$ & $0.03 \pm 0.006$ & $0.04 \pm 0.006$ & 1.00 & $0.04 \pm 0.008$ & $0.04 \pm 0.006$ & 1.00 \\
\hline $\mathrm{E}_{\text {metastases }}$ & $5.33 \pm 0.29$ & $5.27 \pm 0.24$ & 1.00 & $5.31 \pm 0.28$ & $5.27 \pm 0.25$ & 1.00 \\
\hline $\mathrm{U}_{\text {metastases }}$ & $0.03 \pm 0.006$ & $0.03 \pm 0.005$ & 1.00 & $0.03 \pm 0.006$ & $0.03 \pm 0.006$ & 1.00 \\
\hline $\mathrm{E}_{\text {metastases }} / \mathrm{E}_{\text {liver }}$ & $1.04 \pm 0.04$ & $1.04 \pm 0.02$ & 1.00 & $1.04 \pm 0.03$ & $1.03 \pm 0.04$ & 1.00 \\
\hline $\mathrm{U}_{\text {metastases }} / \mathrm{U}_{\text {liver }}$ & $0.87 \pm 0.11$ & $0.88 \pm 0.06$ & 0.92 & $0.86 \pm 0.08$ & $0.90 \pm 0.11$ & 1.00 \\
\hline \multicolumn{7}{|l|}{ Coarse filter } \\
\hline $\mathrm{E}_{\text {liver }}$ & $6.16 \pm 0.41$ & $6.11 \pm 0.40$ & 1.00 & $6.19 \pm 0.43$ & $6.12 \pm 0.41$ & 1.00 \\
\hline $\mathrm{U}_{\text {liver }}$ & $0.03 \pm 0.008$ & $0.03 \pm 0.009$ & 1.00 & $0.03 \pm 0.008$ & $0.03 \pm 0.009$ & 1.00 \\
\hline $\mathrm{E}_{\text {metastases }}$ & $5.90 \pm 1.20$ & $6.46 \pm 0.65$ & 0.94 & $6.23 \pm 0.79$ & $5.82 \pm 1.42$ & 1.00 \\
\hline $\mathrm{U}_{\text {metastases }}$ & $0.03 \pm 0.03$ & $0.02 \pm 0.009$ & 1.00 & $0.02 \pm 0.01$ & $0.04 \pm 0.04$ & 1.00 \\
\hline $\mathrm{E}_{\text {metastases }} / \mathrm{E}_{\text {liver }}$ & $0.96 \pm 0.20$ & $1.06 \pm 0.12$ & 0.77 & $1.01 \pm 0.14$ & $0.95 \pm 0.23$ & 1.00 \\
\hline $\mathrm{U}_{\text {metastases }} / \mathrm{U}_{\text {liver }}$ & $1.23 \pm 1.32$ & $0.72 \pm 0.32$ & 1.00 & $0.90 \pm 0.50$ & $1.38 \pm 1.63$ & 1.00 \\
\hline
\end{tabular}

Note. - Data are the mean $\pm \mathrm{SD}$, all measurements were performed on primary staging

$\mathrm{CT}$ before treatment, significant results are printed in bold.

E: Entropy

U: Uniformity

${ }^{*} P$-values after Holm-Bonferroni correction 
Table 3. Univariable Cox proportional hazards model

\begin{tabular}{|c|c|c|c|}
\hline Parameter & HR & 95\% Confidence Interval & $\boldsymbol{P}$ \\
\hline \multicolumn{4}{|l|}{ Without filter } \\
\hline $\mathrm{E}_{\text {liver }}$ & 0.63 & $0.23-1.73$ & 0.37 \\
\hline $\mathrm{U}_{\text {liver }}$ & 1.04 & $0.95-1.15$ & 0.41 \\
\hline $\mathrm{E}_{\text {metastases }}$ & 2.59 & $1.00-6.65$ & 0.05 \\
\hline $\mathrm{U}_{\text {metastases }}$ & 0.90 & $0.80-1.00$ & 0.05 \\
\hline $\mathrm{E}_{\text {metastases }} / \mathrm{E}_{\text {liver }} \&$ & 2.51 & $1.44-4.36$ & 0.001 \\
\hline $\mathrm{U}_{\text {metastases }} / \mathrm{U}_{\text {liver }}$ & 0.41 & $0.24-0.72$ & 0.002 \\
\hline \multicolumn{4}{|l|}{ Fine Filter } \\
\hline $\mathrm{E}_{\text {liver }}$ & 0.81 & $0.30-2.19$ & 0.67 \\
\hline $\mathrm{U}_{\text {liver }}$ & 1.01 & $0.97-1.05$ & 0.70 \\
\hline $\mathrm{E}_{\text {metastases }}$ & 0.96 & $0.39-2.39$ & 0.93 \\
\hline $\mathrm{U}_{\text {metastases }}$ & 1.00 & $0.96-1.04$ & 0.92 \\
\hline $\mathrm{E}_{\text {metastases }} / \mathrm{E}_{\text {liver }}$ & 1.23 & $0.73-2.07$ & 0.43 \\
\hline $\mathrm{U}_{\text {metastases }} / \mathrm{U}_{\text {liver }}$ & 0.83 & $0.50-1.40$ & 0.49 \\
\hline \multicolumn{4}{|l|}{ Coarse filter } \\
\hline $\mathrm{E}_{\text {liver }}$ & 0.91 & $0.47-1.75$ & 0.77 \\
\hline $\mathrm{U}_{\text {liver }}$ & 1.00 & $0.97-1.03$ & 0.93 \\
\hline $\mathrm{E}_{\text {metastases }}$ & 1.46 & $1.13-1.89$ & 0.004 \\
\hline $\mathrm{U}_{\text {metastases }}$ & 0.98 & $0.96-1.00$ & 0.012 \\
\hline $\mathrm{E}_{\text {metastases }} / \mathrm{E}_{\text {liver }}$ & 1.81 & $1.06-3.09$ & 0.030 \\
\hline $\mathrm{U}_{\text {metastases }} / \mathrm{U}_{\text {liver }}$ & 0.49 & $0.29-0.84$ & 0.009 \\
\hline \multicolumn{4}{|l|}{ Clinical parameters } \\
\hline $\mathrm{Age}^{\S}$ & 1.01 & $0.98-1.04$ & 0.45 \\
\hline Sex & 1.09 & $0.61-1.93$ & 0.78 \\
\hline Location of primary tumour & 0.61 & $0.32-1.18$ & 0.14 \\
\hline Resection of primary tumour ${ }^{\dagger}$ & 0.35 & $0.20-0.62$ & 0.000 \\
\hline Chemotherapy ${ }^{\dagger \S}$ & 0.26 & $0.12-0.57$ & 0.001 \\
\hline Number of CRLM ${ }^{\S}$ & 1.06 & $1.02-1.10$ & 0.006 \\
\hline Resection of CRLM ${ }^{\dagger \S}$ & 0.20 & $0.10-0.41$ & 0.000 \\
\hline Extrahepatic disease $\mathrm{e}^{\ddagger}$ & 1.378 & $1.04-1.83$ & 0.025 \\
\hline
\end{tabular}


Note. - Texture ratios are dichotomized based on the median value, according to methods previously reported ${ }^{34}$, uniformity values were multiplied by 1000 in line with previous research $^{14}$, significant results are printed in bold.

* left sided (transversum, descendens, sigmoid or rectum) / right sided (ascendens or caecum)

$\dagger$ No / Yes

+ No / abdominal only / extra-abdominal metastases

Variables indicated with $\S$ were included in the multivariable model. To avoid overfitting and because of a relation to other variables, the remaining significant variables were not included in the multivariable model (e.g. the vast majority of patients who underwent resection of their liver metastases also underwent resection of their primary tumour)

Table 4. Multivariable Gox proportional hazards model with entropy ratio

\begin{tabular}{lccc}
\hline Parameter & HR & 95\% Confidence Interval & $\boldsymbol{P}$ \\
\hline $\mathrm{E}_{\text {metastases }} / \mathrm{E}_{\text {liver }}$ (without filter) & 1.90 & $0.95-3.78$ & 0.07 \\
Age & 1.02 & $0.99-1.06$ & 0.16 \\
Number of CRLM & 1.00 & $0.96-1.05$ & 0.90 \\
\hline Chemotherapy & & & \\
\hline$\quad$ No & 1.00 & & \\
$\quad$ Yes & 0.42 & $0.18-0.98$ & $\mathbf{0 . 0 4 4}$ \\
\hline Resection of CRLM & & & \\
\hline$\quad$ No & 1.00 & & \\
$\quad$ Yes & 0.26 & $0.11-0.60$ & $\mathbf{0 . 0 0 4}$ \\
\hline Extrahepatic disease & & & \\
\hline$\quad$ No & 1.00 & & 0.74 \\
$\quad$ Abdominal only & 1.12 & $0.59-2.11$ & 0.19 \\
$\quad$ Extra-abdominal & 2.10 & $0.70-6.29$ & \\
\hline
\end{tabular}

Note. - Texture ratios are dichotomized based on the median value, according to methods previously reported ${ }^{34}$, significant results are printed in bold E: Entropy 


\section{Discussion}

The aim of our study was twofold: to test if we could confirm results of previous literature that CT texture analysis has potential value as a predictive imaging marker in patients with CRLM and to get a better insight into the relationship between the texture of CRLM and the surrounding liver architecture. Our results suggest that analyzing the ratios between textural changes of the metastases and the surrounding liver parenchyma $\left(\mathrm{E}_{\text {metastases }} / \mathrm{E}_{\text {liver }}\right.$ and $\left.\mathrm{U}_{\text {metastases }} / \mathrm{U}_{\text {liver }}\right)$ may be of added value to assess the burden of disease in the liver. Moreover, the texture ratios showed an association with overall survival, albeit it not statistically significant in multivariate analyses. Finally, we observed a subtle trend towards higher entropy in liver metastases that show a better response to treatment.

As shown in Figure 3, a more irregular distribution of 'disease' within a certain VOI will typically lead to a higher entropy (and lower uniformity). One can imagine that in the case of a more aggressive disease profile, the liver lesions become more heterogeneous (higher entropy / lower uniformity) while the surrounding liver remains relatively unaffected. This effect on entropy and uniformity in the liver metastases may be highlighted by comparing it to the surrounding liver (as a normalization factor), which may explain why mainly the ratios were significantly associated with the burden of disease while there was only a subtle, nonsignificant trend for the entropy and uniformity measures itself. An alternative hypothesis would be that the ratio between the texture of the liver metastases and surrounding liver is in itself a unique feature that captures biological properties of the course of metastatic disease within the liver that cannot be identified by looking at either the architecture of the liver lesions or surrounding liver separately.

A higher entropy ratio was also an independent factor that was associated with impaired OS (with a borderline significant HR of 1.90 in multivariate analyses) and may thus be of value as an added biomarker of survival, alongside more well-known clinical predictors such as chemotherapy and resection. This is in line with the findings of previous studies in other tumour types: Ganeshan et al. reported that, for oesophageal cancer, high entropy with a medium to coarse filter was associated with a shorter OS ${ }^{24}$. Hayano et al. also suggested that high entropy with a medium filter was associated with a shorter OS in non-small cell lung cancer ${ }^{25}$. In contrast, other groups found the opposite and reported higher entropy (with a fine filter) to be associated with a better OS in patients with head and neck cancer, oesophageal cancer, and colorectal cancer ${ }^{26-28}$. These seemingly 
discrepant findings may in part be related to the fact that different studies used different image filters. The use of edge enhancement filters in texture analysis, such as the LoG filter used in this study, is to improve the ability to assess and quantify tissue heterogeneity. Lower filter values highlight small changes in intensity and structures with fine textures, while higher filter values highlight structures with medium and coarse textures in the filtered image ${ }^{19}$. As such, the use of different filters may considerably affect study results. Moreover, these previous studies report on a heterogeneous group of tumour types with various different treatment regimens and inherently different tumour prognostic profiles.

When looking at the texture of the metastatic lesions itself, only a subtle, nonsignificant trend towards higher entropy was observed for responders versus nonresponders according to RECIST 1.1. We acknowledge that RECIST measurements are suboptimal as an outcome variable given the known limitations of RECIST to accurately assess response ${ }^{29,30}$. However, since the majority of study patients did not undergo resection of their liver metastases, correlation with histopathology was not feasible in our cohort and we chose RECIST as the main outcome as it is still most commonly used in clinical practice as well as in many previous study reports. Interestingly, our results are in line with a previous report of Rao et al. who did use histologic tumour regression grading (TRG) after surgery as the main outcome of response in a small group of 21 patients with CRLM and reported that - similar to our current findings - a non-significant trend towards higher entropy (without filter) in responders versus nonresponders. Rao et al. did find significant results when looking at relative changes in the texture measures after treatment with significantly decreased entropy compared to pre-treatment measurements in responders and increased entropy in nonresponders ${ }^{13}$. Ahn et al. found no significant difference in the pre-treatment entropy between responders and nonresponders to chemotherapy in a relatively large cohort of 235 patients with CRLM. However, they did describe a profile of other features (including skewness and standard deviation) that underlined the theory of a more heterogeneous imaging texture of liver metastases in responders versus nonresponders ${ }^{31}$. Altogether, the results of studies presented so far - including our own - appear to indicate a subtle but not (yet) strong role for pre-treatment textural assessment of CRLM to predict response.

When looking at previous results for whole-liver texture analysis, several studies describe higher entropy in the surrounding liver of patients with CRLM when compared to patients without metastases ${ }^{15,16,32}$. Moreover, Beckers et al. found 
that differences in the texture of the liver parenchyma can already be observed at the time of primary staging (when no visible lesions are apparent) in patients who develop metachronous metastases in the first 6 months after diagnosis, suggesting that liver texture may serve as a marker to predict the early course of disease ${ }^{15}$. Ganeshan et al. showed that GT texture analysis has potential to identify patients at risk for a reduced survival, based on lower entropy ${ }^{33}$. These findings were however described in a group of patients without metastases. Since our cohort only included patients in whom CRLMs were already present, these previously reported findings could not be explored in the current cohort. When it comes to whole-liver texture analysis for the prediction of the extent of disease, treatment response or survival we could not produce any significant findings.

There are some limitations to our study. First, the sample size is relatively small. Second, despite the standardised protocol, there were some differences between the scanners and slice thickness employed throughout this study, although a previous study suggested that scanner settings are of minor influence on the textural features ${ }^{15}$. Third, as already mentioned above, it was not possible to correlate our findings with underlying histopathology since most patients did not undergo resection of their GRLM. Fourth, in the subgroup undergoing chemotherapy, there were some variations in the chemotherapeutic regimen used. Finally, in the field of texture analysis, many features (derived from both first order as well as higher order statistical models) can be tested, which would result in a risk of false positive findings due to multiple testing (type I error). Therefore, for this study, we chose to only include a selection of first-order texture features commonly used in previous literature within the field of texture analysis in colorectal cancer to allow meaningful comparisons with previous evidence ${ }^{15,18,32}$.

In conclusion, our study suggests that the ratio between the texture of liver metastases and the surrounding liver possibly reflects relevant changes in tissue microarchitecture and may be of value in the future to assess the extent of the disease in the liver and to predict overall survival. 


\section{References}

1. Torre LA, Siegel RL, Ward EM, Jemal A. Global Cancer Incidence and Mortality Rates and Trends--An Update. Cancer epidemiology, biomarkers $\mathcal{E}$ prevention : a publication of the American Association for Cancer Research, cosponsored by the American Society of Preventive Oncology 2016; 25(1): 16-27.

2. Leporrier J, Maurel J, Chiche L, Bara S, Segol P, Launoy G. A population-based study of the incidence, management and prognosis of hepatic metastases from colorectal cancer. Br $\mathcal{F}$ Surg 2006; 93(4): 465-74.

3. Manfredi S, Lepage C, Hatem C, Coatmeur O, Faivre J, Bouvier AM. Epidemiology and management of liver metastases from colorectal cancer. Ann Surg 2006; 244(2): 254-9.

4. Noren A, Eriksson HG, Olsson LI. Selection for surgery and survival of synchronous colorectal liver metastases; a nationwide study. Eur 7 Cancer 2016; 53: 105-14.

5. Bipat S, Niekel MC, Comans EF, et al. Imaging modalities for the staging of patients with colorectal cancer. The Netherlands journal of medicine 2012; 70(1): 26-34.

6. Niekel MC, Bipat S, Stoker J. Diagnostic imaging of colorectal liver metastases with CT, MR imaging, FDG PET, and/or FDG PET/CT: a meta-analysis of prospective studies including patients who have not previously undergone treatment. Radiology 2010; 257(3): 674-84.

7. Eisenhauer E, Therasse P, Bogaerts J, et al. New response evaluation criteria in solid tumours: revised RECIST guideline (version 1.1). European journal of cancer 2009; 45(2): 228-47.

8. Robinson PJ. The effects of cancer chemotherapy on liver imaging. Eur Radiol 2009; 19(7): 1752-62.

9. Therasse P, Arbuck SG, Eisenhauer EA, et al. New guidelines to evaluate the response to treatment in solid tumors. European Organization for Research and Treatment of Cancer, National Cancer Institute of the United States, National Cancer Institute of Canada. $\mathcal{F}$ Natl Cancer Inst 2000; 92(3): 205-16.

10. Castellano G, Bonilha L, Li LM, Cendes F. Texture analysis of medical images. Clinical radiology 2004; $\mathbf{5 9}(12)$ : 1061-9.

11. Lubner MG, Stabo N, Lubner SJ, et al. CT textural analysis of hepatic metastatic colorectal cancer: pre-treatment tumor heterogeneity correlates with pathology and clinical outcomes. Abdom Imaging 2015; 40(7): 2331-7.

12. Miles KA, Ganeshan B, Griffiths MR, Young RC, Chatwin GR. Colorectal cancer: texture analysis of portal phase hepatic CT images as a potential marker of survival. Radiology 2009; 250(2): 444-52.

13. Rao SX, Lambregts DM, Schnerr RS, et al. CT texture analysis in colorectal liver metastases: A better way than size and volume measurements to assess response to chemotherapy? United European Gastroenterol 7 2016; 4(2): 257-63.

14. Caruso D, Zerunian M, Ciolina M, et al. Haralick's texture features for the prediction of response to therapy in colorectal cancer: a preliminary study. Radiol Med 2017.

15. Beckers RCJ, Lambregts DMJ, Schnerr RS, et al. Whole liver CT texture analysis to predict the development of colorectal liver metastases - A multicentre study. European journal of radiology 2017; 92: 64-71.

16. Rao SX, Lambregts DM, Schnerr RS, et al. Whole-liver CT texture analysis in 
colorectal cancer: Does the presence of liver metastases affect the texture of the remaining liver? United European Gastroenterol 7 2014; 2(6): 530-8.

17. Griethuysen van JJM, Fedorov A, Parmar C, et al. Computational Radiomics System to Decode the Radiographic Phenothype. 2017.

18. Ganeshan B, Miles KA, Young RC, Chatwin CR. Hepatic entropy and uniformity: additional parameters that can potentially increase the effectiveness of contrast enhancement during abdominal CT. Clinical radiology 2007; 62(8): 761-8.

19. Davnall F, Yip CS, Ljungqvist G, et al. Assessment of tumor heterogeneity: an emerging imaging tool for clinical practice? Insights Imaging 2012; 3(6): 573-89.

20. Ganeshan B, Miles KA. Quantifying tumour heterogeneity with CT. Cancer imaging : the official publication of the International Cancer Imaging Society 2013; 13: 140-9.

21. Chen C, Pau L, Wang P. The Handbook of Pattern Recognition and Computer Vision, 1998. World Scienti: 207-48.

22. Weiser MR, Jarnagin WR, Saltz LB. Colorectal cancer patients with oligometastatic liver disease: what is the optimal approach? Oncology (Williston Park) 2013; 27(11): 1074-8.

23. Holm S. A simple sequentially rejective multiple test procedure. Scandinavian journal of statistics 1979: 65-70.

24. Ganeshan B, Skogen K, Pressney I, Coutroubis D, Miles K. Tumour heterogeneity in oesophageal cancer assessed by CT texture analysis: preliminary evidence of an association with tumour metabolism, stage, and survival. Clin Radiol 2012; 67(2): 157-64.

25. Hayano K, Kulkarni NM, Duda DG, Heist RS, Sahani DV. Exploration of Imaging Biomarkers for Predicting Survival of Patients With Advanced Non-Small Cell Lung Cancer Treated With Antiangiogenic Chemotherapy. AfR Am $\mathcal{f}$ Roentgenol 2016; 206(5): 987-93.

26. Ng F, Ganeshan B, Kozarski R, Miles KA, Goh V. Assessment of primary colorectal cancer heterogeneity by using whole-tumor texture analysis: contrast-enhanced CT texture as a biomarker of 5-year survival. Radiology 2013; 266(1): 177-84.

27. Yip C, Landau D, Kozarski R, et al. Primary esophageal cancer: heterogeneity as potential prognostic biomarker in patients treated with definitive chemotherapy and radiation therapy. Radiology 2014; 270 (1): 141-8.

28. Zhang H, Graham CM, Elci O, et al. Locally advanced squamous cell carcinoma of the head and neck: CT texture and histogram analysis allow independent prediction of overall survival in patients treated with induction chemotherapy. Radiology 2013; 269(3): 801-9.

29. Chun YS, Vauthey J-N, Boonsirikamchai P, et al. Association of computed tomography morphologic criteria with pathologic response and survival in patients treated with bevacizumab for colorectal liver metastases. FAMA 2009; 302(21): 2338-44.

30. Chung WS, Park MS, Shin SJ, et al. Response evaluation in patients with colorectal liver metastases: RECIST version 1.1 versus modified CT criteria. AfR Am $\mathcal{J}$ Roentgenol 2012; 199(4): 809-15.

31. Ahn SJ, Kim JH, Park SJ, Han JK. Prediction of the therapeutic response after FOLFOX and FOLFIRI treatment for patients with liver metastasis from colorectal cancer using computerized CT texture analysis. European journal of radiology 2016; 85(10): 1867-74.

32. Ganeshan B, Miles KA, Young RC, Chatwin CR. Texture analysis in non-contrast 
enhanced CT: impact of malignancy on texture in apparently disease-free areas of the liver. Eur 7 Radiol 2009; 70(1): 101-10.

33. Ganeshan B, Miles KA, Young RC, Chatwin CR. Hepatic enhancement in colorectal cancer: texture analysis correlates with hepatic hemodynamics and patient survival. Academic radiology 2007; 14(12): 1520-30.

34. Altman DG, Royston P. The cost of dichotomising continuous variables. BMF 2006; 332(7549): 1080. 


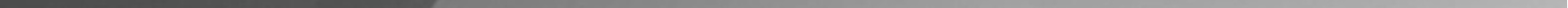




\section{Quantitative imaging of the liver in colorectal cancer patients: a comparison between diffusion- weighted MRI and CT texture analysis}

Rianne C.J. Beckers, Stefano Trebeschi, Monique Maas, Geerard L. Beets, Janneke B. Houwers, Regina G.H. Beets-Tan, Doenja M.J Lambregts 
7. General Discussion 


\section{General discussion}

The time that imaging could solely provide information about tumour size and morphology has passed. In recent years, we have seen enormous developments in the field of functional imaging and advanced image post-processing, allowing us to extract imaging biomarkers that can provide novel insights into underlying biological tissue properties. One of such techniques is 'texture analysis'. Texture analysis is an example of an image post-processing technique where 'routine' diagnostic imaging data such as CT or MRI are re-assessed with the help of statistical or mathematical models without the need for extra image acquisitions, or advanced computational software.

A variety of methods exist to derive texture features from an image ${ }^{1}$. With the most basic statistical-based methods (such as the ones used in this thesis), we evaluate the frequency and spatial distribution of signal intensities within a certain region of interest in an image, for example within the liver on a routine diagnostic CT image ${ }^{1,2}$. When this spatial distribution is more irregular, it is associated with a more heterogeneous underlying tissue microarchitecture, while vice versa a more regular distribution of signal intensities correlates with a more homogeneous tissue structure ${ }^{3}$. Two commonly used texture features in this respect are 'uniformity' (a feature reflecting a more homogeneous distribution) and 'entropy' (a more or less opposite feature reflecting a higher heterogeneity) $)^{4}$ In oncology, heterogeneity is known to be associated with tumour biology. Although the exact bio-oncological substrate for individual texture features is not fully understood, measures of heterogeneity appear to be related to intratumoural spatial variations in cellularity, angiogenesis, extracellular matrix and necrosis ${ }^{3}$.

Potential clinical applications of texture analysis are emerging and the topic of an increasing number of research studies. So far studies have mainly focussed on texture analysis in a pre-clinical setting, with limited data on its function as a predictor of clinical outcome. With this thesis, we aimed to further build the evidenced base for the potential clinical value of CT texture analysis in oncology, in specific for the clinical management of patients with colorectal liver metastases. To achieve this, we have first focussed on studying the potential of whole-liver CT texture analysis in predicting the course of metastatic disease. Previous work in this field has been conducted by the groups of Rao et al and Ganeshan et al. They both described that texture features derived from the apparently normal (non-diseased) liver parenchyma in patients with colorectal cancer may contain potentially valuable information that can help to establish the presence of met- 
astatic disease within the liver ${ }^{5,6}$. Apparently, the texture of the whole liver is altered when patients are affected by hepatic metastases. Ganeshan et al stated that these changes in liver texture are related to the total hepatic blood flow and glucose metabolism ${ }^{7,8}$. From a clinical point of view, it is interesting to see whether these changes in liver texture already occur before focal metastatic lesions become apparent within the liver. If so, whole liver texture analysis may have potential to predict the course of metastatic disease. In Chapter 3, we confirmed results of previous studies that there is a difference in the whole liver texture of patients with and without present colorectal liver metastases. In particular, we found low uniformity, indicating an overall more heterogeneous liver microarchitecture in patients with metastases. Although the exact mechanism is not fully known, changes in liver texture as a result of metastatic involvement have been proposed to be related to changes in liver perfusion or changes on a cellular level caused by the presence of micro metastases ${ }^{8-10}$. Interestingly, similar changes in liver texture were also observed in patients who presented without metastases at the time of diagnosis but proceeded to develop liver metastases within 6 months. This suggests that whole liver CT texture analysis also has potential to predict patients at risk of developing early metachronous liver metastases during the course of their disease. However, whole liver texture analysis did not prove to be robust enough to identify patients at risk of developing metastases at a later stage (within one or two years), for which there could be two logical explanations. First, it may be that in patients that develop metastases after one to two years, no changes are present yet in the liver parenchyma at the time of primary diagnosis. Alternatively, subtle changes may already be occurring at that time, but too small to be detected with our current techniques.

As a follow-up of the study in Chapter 3, we wanted to find out whether the predictive power of our texture approach could be improved by performing a segmental texture analysis instead of a whole liver analysis. The rationale for this approach would be that the textural changes could be more localized to a certain area within the liver (i.e., the specific site where at a later stage the metastases will become visible) and more related to focal changes on a cellular level (i.e., presence of occult micrometastases) compared to more generalized parenchymal changes. If so, we hypothesized that a segmental texture analysis should better predict the occurrence of metastases in specific parts of the liver. The results described in Chapter 4, however, do not support this hypothesis as changes in texture on a segmental level were less apparent than texture changes derived from the whole liver, which appears to favour the hypothesis that the texture changes we measure 
are related to more diffuse parenchymal changes. We believe that these are likely related to changes in liver perfusion and hepatic hemodynamics ${ }^{8,11}$. With this in mind, one can imagine that texture measures may be influenced and therefore highlighted according to the timing of image acquisition after contrast injection. It has indeed previously been demonstrated that contrast timing in GT can significantly affect texture measurements. For example, in previous studies by Ganeshan et al, results for liver CT analyses were more significant when using arterial phase scans ${ }^{7,12}$. In our studies we mainly used portal venous phase contrast scans as in common clinical practice this is often the only phase that is routinely acquired. The potential benefit of adding extra (dynamic) contrast phases therefore remains to be investigated by future studies.

Second, we aimed to explore the possibilities of CT texture analysis as a biomarker for the prediction of response to therapy and survival. As a first exploratory step, in Chapter 2 we performed a literature review to study the available evidence on the prediction of response to chemotherapy in colorectal liver metastases using various imaging techniques, including texture analysis. Most promising results so far have been reported for functional MR imaging, in specific diffusion-weighted imaging. With regard to texture analysis, evidence so far is sparse. Only one report by Rao et al specifically addressed the use of CT texture features of metastatic liver lesions to predict response to chemotherapy in colorectal can$\operatorname{cer}^{15}$. They found that changes in CT texture measures after treatment ( $\Delta$ uniformity and $\Delta$ entropy) outperformed RECIST and tumour volume measurements to assess the treatment response after completion of chemotherapy, but none of the texture features was beneficial in predicting treatment response beforehand. This is in line with the findings described in Chapter 5. Neither texture features derived from the metastatic liver lesions, nor the background liver parenchyma were capable of predicting response to chemotherapy pre-treatment. Similarly, no significant results were found for the prediction of survival using whole liver or lesional texture features. Interestingly, however, when a ratio was calculated by dividing the texture of the metastatic lesion by the texture of the whole liver parenchyma, results improved considerably. Apparently clinically relevant changes in texture can be highlighted by looking at the relation between the texture of the liver lesions itself and the background liver. An increased lesion-to-liver entropy ratio (albeit not significant) was associated with a poorer overall survival. Moreover, texture ratios were associated with the extent of metastatic disease in the liver. Although, to our knowledge, we are the first to report on using ratios between the texture of liver metastases and the background liver in such a way, 
our results support the findings of previous studies that reported significant correlations between texture features and survival, both in colorectal liver metastases as well as in other tumour types ${ }^{11,13}$.

We have encountered some challenges when investigating the clinical potential of CT texture analysis in colorectal liver metastases. Our group is one of the first to perform a clinical study on CT texture in a multicentre setting. This involved dealing with differences in hardware, scan protocols and acquisition-related parameters within the participating centres. An important challenge was to properly take these effects into account. In our multicentre study in Chapter 3, we tried to compensate for such effects by performing a multilevel analysis per CT scanner. However, we could not fully rule out potential confounding effects. Several studies have indicated that factors such as slice thickness, contrast timing and CT acquisition parameters (i.e. $\mathrm{kVp}$ and slice collimation) may influence texture features, although the exact effects are still unknown $n^{7,8,11,13,14}$. Also, there are several different methods to conduct texture analysis. In this thesis, we have solely explored first order statistics features. As with other imaging techniques, standardisation of protocols and analysis methods is an important item that deserves attention in future research to further facilitate the implementation of texture as an imaging biomarker.

As a final step of this thesis, we aimed to put texture analysis in perspective with regard to other currently highly researched techniques, especially diffusion-weighted MRI (DWI). DWI bases its contrast mainly on changes in tissue cellularity and has been shown to be highly sensitive and superior to CT, PETCT, and ultrasound for the detection of small focal liver lesions ${ }^{15}$. Furthermore, quantification of liver diffusion by means of the apparent diffusion coefficient (ADC) has shown promise for lesion characterization and prognosticating the response of colorectal liver metastases to chemotherapy and radiotherapy ${ }^{16,17}$. In a previous report by our group (Lambregts et al.) on liver DWI-MRI histogram analysis, significant differences were found when comparing the whole liver $\mathrm{ADC}$ of patients with colorectal liver metastases to that of healthy controls ${ }^{18}$. In our study in Chapter 3 on CT texture analysis, we found similar differences in the whole liver texture features between colorectal cancer patients with and without any metastatic liver disease. As such, we believed it would be interesting to compare ADC and texture features of the liver in colorectal cancer patients, which resulted in the study presented in Chapter 6. Only a few weakly significant correlations were found between CT texture features and ADC- related 
parameters derived from DWI-MRI. This makes sense since the two techniques are distinctly different. Whereas texture analysis focuses on tissue heterogeneity, DWI provides a measure of a tissue's cellular microarchitecture by assessing the diffusivity of water protons. Although a potential relation with corresponding (micro)perfusional changes has been proposed for both DWI ${ }^{19}$ and texture analy$\operatorname{ses}^{8}$, the underlying mechanism of action is thus different for the two techniques. Moreover, there is a considerable difference in image resolution and soft tissue contrast between CT and MRI, which will likely also affect results. Interestingly, in the study in Chapter 6, none of the ADC-related parameters showed significant differences between normal liver parenchyma and metastatic liver lesions, while multiple texture features (especially entropy and uniformity with a medium to coarse filter) were distinctly different in the metastases. This at first seems contra-intuitive since - when visually assessing DWI-MRI - the difference in signal between metastases and the normal background liver is much more pronounced. This has to do with the way the diffusion images are displayed. Typically, a very narrow window-width is chosen, which greatly exaggerates differences between the metastases and background liver (although small in an absolute sense), thereby highlighting the metastases. Although DWI can thus certainly be of help to detect metastases, from a quantitative point of view, texture analysis appears to better equipped to characterize metastatic tissue within the liver ${ }^{20-22}$. 


\section{Summary and Recommendations}

The aim of this thesis was to build on evidence for the use of CT texture analysis as a biomarker in colorectal liver metastases. We have gained a better understanding of the relationship between texture analysis and the amount of metastatic disease in colorectal cancer. We have been able to confirm that there is a potential clinical value in textural analysis particularly for assessing the presence and severity of disease in the liver and thereby estimating the risk of developing metachronous metastases early after diagnosis. In addition, there seems to be valuable information contained in studying the ratio of the texture of metastatic liver lesions and the surrounding liver parenchyma. The main challenge for translating this further into clinical practice is to overcome practical limitations related to variations in measurements caused by hardware and acquisition-related differences, which can make multicentre research challenging. Future studies should, therefore, aim at gaining a better understanding of these effects so that they can be taken into account in upcoming studies to enable potential clinical implementation. Moreover, future research should focus on further establishing the role of quantitative imaging techniques such as textural analysis and on combining different quantitative imaging biomarkers with other histopathological markers, clinical features and genomics to develop comprehensive clinical models to further facilitate personalised cancer treatment. Finally, image quantification typically requires manual delineation of tumours and/or organs, which is time-consuming and influenced by human error. As such deep learning and automated segmentation techniques should be further developed to facilitate more quantitative research in the future. 


\section{References}

1. Ganeshan B, Miles KA. Quantifying tumour heterogeneity with CT. Cancer imaging : the official publication of the International Cancer Imaging Society 2013; 13: 140-9.

2. Materka A, Strzelecki M. Texture analysis methods-a review. Technical university of lodz, institute of electronics, COST B11 report, Brussels 1998: 9-11.

3. Davnall F, Yip CS, Ljungqvist G, et al. Assessment of tumor heterogeneity: an emerging imaging tool for clinical practice? Insights Imaging 2012; 3(6): 573-89.

4. Miles KA, Ganeshan B, Hayball MP. CT texture analysis using the filtration-histogram method: what do the measurements mean? Cancer imaging : the official publication of the International Cancer Imaging Society 2013; 13(3): 400-6.

5. Rao SX, Lambregts DM, Schnerr RS, et al. Whole-liver CT texture analysis in colorectal cancer: Does the presence of liver metastases affect the texture of the remaining liver? United European gastroenterology journal 2014; 2(6): 530-8.

6. Ganeshan B, Miles KA, Young RC, Chatwin CR. Texture analysis in non-contrast enhanced CT: impact of malignancy on texture in apparently disease-free areas of the liver. Eur $f$ Radiol 2009; 70(1): 101-10.

7. Ganeshan B, Miles KA, Young RC, Chatwin CR. Hepatic entropy and uniformity: additional parameters that can potentially increase the effectiveness of contrast enhancement during abdominal CT. Clinical radiology 2007; 62(8): 761-8.

8. Ganeshan B, Miles KA, Young RC, Chatwin CR. In search of biologic correlates for liver texture on portal-phase CT. Academic radiology 2007; 14(9): 1058-68.

9. Guenod C, Leconte I, Siauve N, et al. Early changes in liver perfusion caused by occult metastases in rats: detection with quantitative CT. Radiology 2001; 218(2): 556-61.

10. Leen E. The detection of occult liver metastases of colorectal carcinoma. Fournal of hepato-biliary-pancreatic surgery 1999; 6(1): 7-15.

11. Ganeshan B, Miles KA, Young RC, Chatwin CR. Hepatic enhancement in colorectal cancer: texture analysis correlates with hepatic hemodynamics and patient survival. Acad Radiol 2007; 14(12): 1520-30.

12. Ganeshan B, Burnand K, Young R, Chatwin C, Miles K. Dynamic contrast-enhanced texture analysis of the liver: initial assessment in colorectal cancer. Invest Radiol 2011 ; 46 (3): 160-8.

13. Miles KA, Ganeshan B, Griffiths MR, Young RC, Chatwin CR. Colorectal cancer: texture analysis of portal phase hepatic CT images as a potential marker of survival. Radiology 2009; 250(2): 444-52.

14. Bezy-Wendling J, Kretowski M, Rolland Y, Le Bidon W. Toward a better understanding of texture in vascular CT scan simulated images. IEEE transactions on bio-medical engineering 2001; $\mathbf{4 8}$ (1): 120-4.

15. Kenis C, Deckers F, De Foer B, Van Mieghem F, Van Laere S, Pouillon M. Diagnosis of liver metastases: can diffusion-weighted imaging (DWI) be used as a stand alone sequence? European journal of radiology 2012; 81(5): 1016-23.

16. Cui Y, Zhang XP, Sun YS, Tang L, Shen L. Apparent diffusion coefficient: potential imaging biomarker for prediction and early detection of response to chemotherapy in hepatic metastases. Radiology 2008; 248(3): 894-900.

17. Koh DM, Scurr E, Collins D, et al. Predicting response of colorectal hepatic me- 
tastasis: value of pretreatment apparent diffusion coefficients. AfR Am $\mathcal{F}$ Roentgenol 2007; 188(4): 1001-8.

18. Lambregts DM, Martens MH, Quah RC, et al. Whole-liver diffusion-weighted MRI histogram analysis: effect of the presence of colorectal hepatic metastases on the remaining liver parenchyma. European journal of gastroenterology \& hepatology 2015; 27(4): 399-404.

19. Sehy JV, Ackerman JJ, Neil JJ. Evidence that both fast and slow water ADC components arise from intracellular space. Magn Reson Med 2002; 48(5): 765-70.

20. Bipat S, Niekel MC, Comans EF, et al. Imaging modalities for the staging of patients with colorectal cancer. The Netherlands journal of medicine 2012; 70(1): 26-34.

21. Bipat S, van Leeuwen MS, Comans EF, et al. Colorectal liver metastases: CT, MR imaging, and PET for diagnosis--meta-analysis. Radiology 2005; 237(1): 123-31.

22. Niekel MC, Bipat S, Stoker J. Diagnostic imaging of colorectal liver metastases with CT, MR imaging, FDG PET, and/or FDG PET/CT: a meta-analysis of prospective studies including patients who have not previously undergone treatment. Radiology 2010; 257(3): 674-84. 

8. Summary / Samenvatting 


\section{Summary}

The aim of this thesis was to investigate the current role of imaging techniques in the assessment of colorectal liver metastases and to determine the possible added value of new techniques, in particular, CT texture analysis.

In chapter 2 we studied the role of PET, PET-CT, CT and MRI in a systematic review of 16 radiological studies to predict the response to chemotherapy in patients with colorectal liver metastases. First of all, it turned out that the available literature was relatively scarce and extremely heterogeneous, which made it difficult to draw firm conclusions. Nevertheless, ADC appears to be a promising technique in the prediction of response to chemotherapy. A striking finding, moreover, was that techniques that predicted a good RECIST or metabolic response were also often associated with a shorter survival in patients with colorectal liver metastases.

Chapter 3 describes a multicentre study investigating the value of CT texture analysis to assess the presence of synchronous metastatic disease in the liver and predict the development of metachronous colorectal liver metastases. Through CT texture analysis, we were able to distinguish between patients with and without colorectal liver metastases. We were also able to predict the occurrence of liver metastases within 6 months after diagnosis, but the technique was not robust enough to predict the occurrence of metachronous in the longer term.

In the study in chapter 4, we aimed to further improve our method of CT texture analysis described in chapter 3 by investigating whether a separate analysis of the texture in different liver segments offers added value above the assessment of the average texture of the whole liver volume. However, the more detailed segmental registration did not prove to be of added value to predict metachronous disease. This indirectly suggests that changes in CT texture measured in the liver appear to be due to changes diffusely distributed throughout the liver parenchyma and less likely to be caused by occult local disease.

In chapter 5 we analysed the relationship ('ratio') between the CT texture of metastases in the liver and the surrounding normal liver parenchyma with the aim of gaining a better understanding in the underlying disease mechanism. This ratio was significantly different in patients with a limited number of metastases compared to patients with extensive liver metastases, indicating that texture 
ratios may be of added value to predict the burden of disease. Moreover, we saw a trend that texture ratios may also be of value for predicting the response to chemotherapy and survival in the longer term.

In chapter 6 we investigated whether correlations exist between parameters obtained by CT texture analysis and parameters from diffusion-weighted MRI of the liver in patients with colorectal cancer. We compared measurements obtained from liver metastases with measurements from different parts of the healthy liver parenchyma. There were only a few weak correlations between CT texture and DWI-related parameters, but no correlation was found for the majority of the tested parameters. CT texture parameters was better able to quantitatively distinguish between normal liver parenchyma and metastases. In addition, texture measurements were less sensitive to measurement variations within the normal parenchyma and were, therefore, more robust than DWI-related parameters. 


\section{Samenvatting}

Het doel van dit proefschrift was om de huidige rol van beeldvormende technieken te onderzoeken in de beoordeling van colorectale levermetastasen en om te bepalen wat de mogelijk toegevoegde waarde is van nieuwe technieken, in het bijzonder CT textuur analyse.

In hoofdstuk 2 bestudeerden we middels een systematische review van 16 radiologische studies de rol van PET, PET-CT, CT en MRI om de respons op chemotherapie te voorspellen in patiënten met colorectale levermetastasen. Allereerst bleek dat de beschikbare literatuur relatief schaars en uitermate heterogeen was, wat het lastig maakt harde conclusies te trekken. Desondanks lijkt ADC een veelbelovende techniek te zijn in de voorspelling van respons op chemotherapie. Een opvallende bevinding was bovendien dat technieken die een goede RECIST of metabole respons voorspelden vaak tevens geassocieerd waren met een kortere overleving in patiënten met colorectale levermetastasen.

Hoofdstuk 3 beschrijft een multicentrische studie waarin de waarde van CT textuur analyse werd onderzocht voor het voorspellen van de aanwezigheid van synchrone metastatische ziekte in de lever en het ontstaan van metachrone colorectale levermetastasen. Middels CT textuur analyse konden we een onderscheid maken tussen patiënten met en zonder colorectale levermetastasen. De techniek was tevens in staat om het ontstaan van levermetastasen binnen 6 maanden na diagnose te voorspellen, maar niet robuust genoeg om het ontstaan van metachrone op langere termijn te voorspellen.

In de studie in hoofdstuk 4 hebben we getracht onze methode van textuuranalyse beschreven in hoofdstuk 3 verder te verbeteren door te onderzoeken of het separaat analyseren van de textuur in verschillende leversegmenten meerwaarde biedt boven het beoordelen van de gemiddelde textuur van de gehele lever. De meer gedetailleerde segmentele intekening bleek echter niet van meerwaarde om metachrone ziekte te voorspellen. Dit suggereert indirect dat textuurveranderingen gemeten in de lever lijken te berusten op veranderingen diffuus verspreid door het gehele lever parenchym en minder waarschijnlijk worden veroorzaakt door occulte lokale ziekte.

In hoofdstuk 5 analyseerden we de relatie ('ratio') tussen de CT textuur van metastasen in de lever en het omringend normaal leverparenchym met als doel 
een beter inzicht te krijgen in het onderliggende ziektemechanisme. Deze ratio was significant anders in patiënten met een beperkte hoeveelheid metastasen in vergelijking met patiënten met uitgebreide levermetastasen, indicerend dat textuur ratio's van meerwaarde kunnen zijn om de ziektelast te voorspellen. Bovendien zagen we een trend dat textuur ratio's mogelijk ook van waarde kunnen zijn voor het voorspellen van de respons op chemotherapie en de overleving op langere termijn.

In hoofdstuk 6 onderzochten we of er correlaties bestaan tussen parameters verkregen middels CT textuur analyse en parameters uit diffusie-gewogen MRI van de lever bij patiënten met een colorectaal carcinoom. We vergeleken hierbij metingen verkregen uit levermetastasen met metingen uit verschillende delen van het gezonde leverparenchym. Er waren slechts enkele zwakke correlaties tussen CT textuur en DWI-gerelateerde parameters, maar voor het merendeel van de geteste parameters werd geen correlatie gevonden. CT textuur parameters bleken daarnaast beter in staat om kwantitatief het onderscheid te maken tussen normaal leverweefsel en metastasen. Textuur metingen bleken bovendien minder gevoelig voor meetvariaties binnen het normale parenchym en waren derhalve robuuster dan DWI-gerelateerde parameters. 


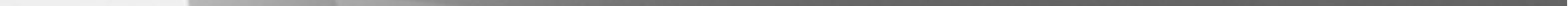


9. Valorisation addendum 


\section{Valorisation addendum}

Colorectal cancer (CRC) is the most common form of cancer in The Netherlands, with 15.550 new cases in $2015^{1}$. Incidence is expected to rise to 17.000 new cases in 2020 because of the implementation of the nationwide screening program, the growing incidence (especially in men) and the growing and ageing population ${ }^{1}$. Once GRC is diagnosed, the next step is to determine its stage. The stage of GRC is based on the local tumour extent and on whether there are signs of cancer spread to lymph nodes and other organs. This is typically assessed with imaging, including a CT scan or MRI of the abdomen and a CT scan or X-ray of the chest. In case of stage IV cancer, cancer has spread to distant organs, with one of the most important sites of metastases being the liver. This is considered 'advanced' CRC and is generally treated with chemotherapy. Some patients may benefit from chemotherapy with even a curative path in combination with surgery. However, there are still many patients for whom chemotherapy will only be a palliative solution. To date, we still have an insufficient insight into which factors determine the course of the disease and consequently to determine which patients are at risk to develop advanced disease ${ }^{2}$. Moreover, once the metastatic disease is present it remains unclear which patients will likely show a good response to treatment and which patients will not.

So far, the mainstay of imaging evaluation has been to assess the morphology (e.g. shape, signal) and size of tumour lesions ${ }^{3}$. In other words, we have so far mainly focussed on things that can be appreciated by the 'naked eye'. There is, however, much more information 'hidden' in images that could potentially provide us with more in-depth knowledge about the underlying tumour biology. This information can be distilled when we look at images with more sophisticated methods. An example of such a method is CT texture analysis, which is a mathematical method that assesses the distribution of signal intensities on CT images ${ }^{4}$.

\section{Relevance}

The results of this thesis show that CT texture analysis can be a useful adjunct for the imaging of colorectal liver metastases as it can provide quantitative 'imaging markers' to predict the course of the disease. For example, texture analysis has shown capable of predicting the occurrence of metastases within six months after diagnosis, which enables an early selection of patients at risk of developing metastases. This is in line with the current trend to promote "personalised medicine", which means that medical decisions, practices, interventions and/ 
or products are tailored to the individual patient, based on their predicted disease risk profile. In future practice, novel imaging tools such as texture analysis may thus aid in optimising treatment for individual patients, thereby aiming to ultimately improve outcome and survival. Moreover, when patients can be better informed about their risk profile, this can lead to a better-informed decisionmaking process between doctor and patient.

\section{Target population}

There are several people who could benefit from the results presented in this thesis (once properly validated and confirmed by further studies). First, obviously, all colorectal cancer patients can benefit from CT texture analysis as it is a noninvasive tool that can provide the patient's treating physicians with additional information that provides a better insight into their disease and can thus help optimise treatment to obtain the best possible outcome. Second, healthcare professionals who are in the decision-making process among patients with GRC could benefit from the 'imaging biomarkers' provided by texture analysis. Finally, in the field of radiology, the results obtained with texture analysis in colorectal cancer may be extrapolated and explored further in other malignancies, but also in other non-oncologic conditions including chronic liver disease such as steatosis and cirrhosis. Further research is needed, to explore these opportunities.

\section{Products}

Currently, there are a few commercial products available that incorporate texture analysis within daily used imaging software. This is mainly because to date, evidence on the clinical utility of texture analysis is still relatively sparse. Once the clinical added value is confirmed by further and larger studies, the incorporation of texture analysis into clinical imaging tools should be further explored therewith building on the important bridge between research and clinical practice.

\section{Innovation and future}

Up until now, CT texture analysis has not been part of daily radiological clinical practice. With this thesis, we aimed to give an overview of the current potential of this method and its possible beneficial role as a clinical diagnostic tool. Future research should focus on building on this preliminary evidence by performing large-scale validation studies, detailed correlation with pathology and standardisation of scanning protocols. 
Moreover, it will be interesting to apply texture analysis as a post-processing method not only to CT data but also to MRI sequences including both routine morphological sequences as well as exciting novel functional imaging techniques such as diffusion-weighted and perfusion imaging that focus on more and more specific aspects of the tumour biology. Finally, imaging features such as texture should be combined with other clinical features such as histopathology and genomics in order to build smart multiparametric clinical models that can offer comprehensive insights into a patient's disease profile and prognosis. 


\section{References}

1. Cijfers over kanker. 2015. http://www.cijfersoverkanker.nl2017).

2. Manfredi S, Lepage C, Hatem C, Coatmeur O, Faivre J, Bouvier AM.

Epidemiology and management of liver metastases from colorectal cancer. Annals of surgery 2006; 244(2): 254-9.

3. Eisenhauer E, Therasse P, Bogaerts J, et al. New response evaluation criteria in solid tumours: revised RECIST guideline (version 1.1).

European journal of cancer 2009; 45(2): 228-47.

4. Ganeshan B, Miles KA. Quantifying tumour heterogeneity with CT. Cancer imaging : the official publication of the International Cancer Imaging Society 2013; 13: 140-9. 


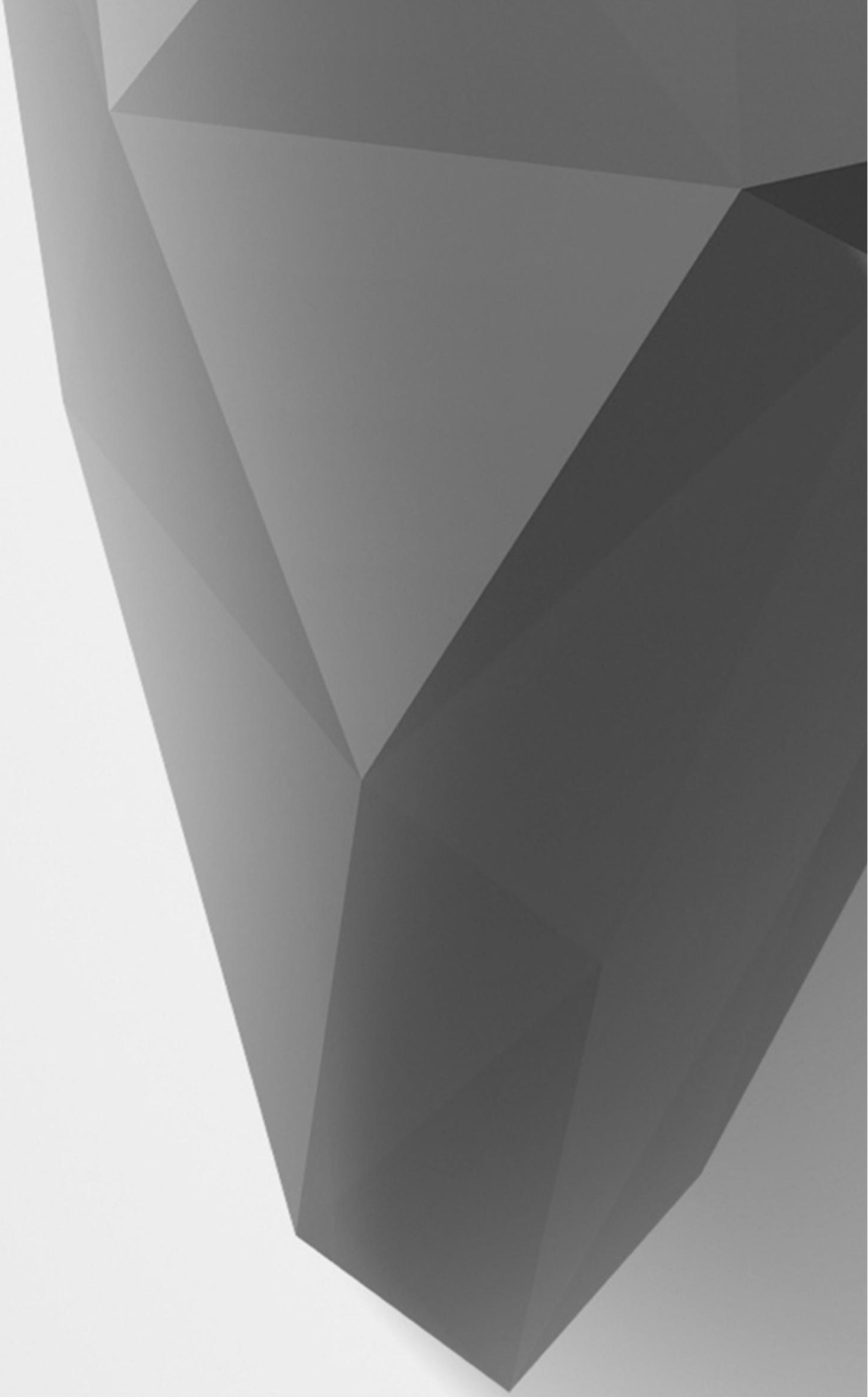




\section{List of publications}

Beckers RCJ, van der Linden FThMP, Oomen APA. Centralisatie van zorg rondom electieve aneurysmachirurgie - Een retrospectieve analyse in een perifere, niet-opleidingskliniek.

Nederlands tijdschrift voor Heelkunde 23.5 (2014): 46-49

Beckers RCJ, Beets-Tan RGH, Schnerr RS, Maas M, da Costa Andrade LA, Beets GL, Dejong CHC, Houwers JB, Lambregts DMJ. Whole-volume vs. segmental CT texture analysis of the liver to assess metachronous colorectal liver metastases. Abdominal Radiology 42.11 (2017): 2639-2645.

Beckers RCJ, Lambregts DMJ, Schnerr RS, Maas M, Rao S-X, Kessels AGH, Thywissen T, Beets GL, Trebeschi S, Houwers JB, Dejong CHC, Verhoef C, Beets-Tan RGH. Whole liver CT texture analysis to predict the development of colorectal liver metastases - A multicenter study. European journal of radiology 92 (2017): 64-71.

Beckers RCJ, Trebeschi S, Schnerr RS, Maas M, Sijmons JML, Beets GL, Houwers JB, Beets-Tan RGH, Lambregts DMJ. CT texture analysis in colorectal liver metastases and the surrounding liver parenchyma and its potential as an imaging biomarker of disease aggressiveness, response and survival. European journal of radiology 102 (2018): 15-21.

Beckers RCJ, Lambregts DMJ, Lahaye MJ, Rao S-X, Kleinen K, Grootscholten C, Beets GL, Beets-Tan RGH, Maas M. Advanced imaging to predict response to chemotherapy in colorectal liver metastases - a systematic review. HPB 20.2 (2018): 120-127.

Rao S-X, Lambregts DMJ, Schnerr RS, Beckers RCJ, Maas M, Albarello F, Riedl RG, Dejong CHC, Martens MH, Heijnen LA, Backes WH, Beets GL, Zeng M-S, Beets-Tan RGH. CT texture analysis in colorectal liver metastases: a better way than size and volume measurements to assess response to chemotherapy? United European Gastroenterology Journal 4.2 (2016): 257-263. 
de Jong MC, Beckers RCJ, van Woerden V, Sijmons JML, Bemelmans MHA, van Dam RM, Dejong CHC. The liver-first approach for synchronous colorectal liver metastases: more than a decade of experience in a single centre. HPB (2018) epub ahead of print. 


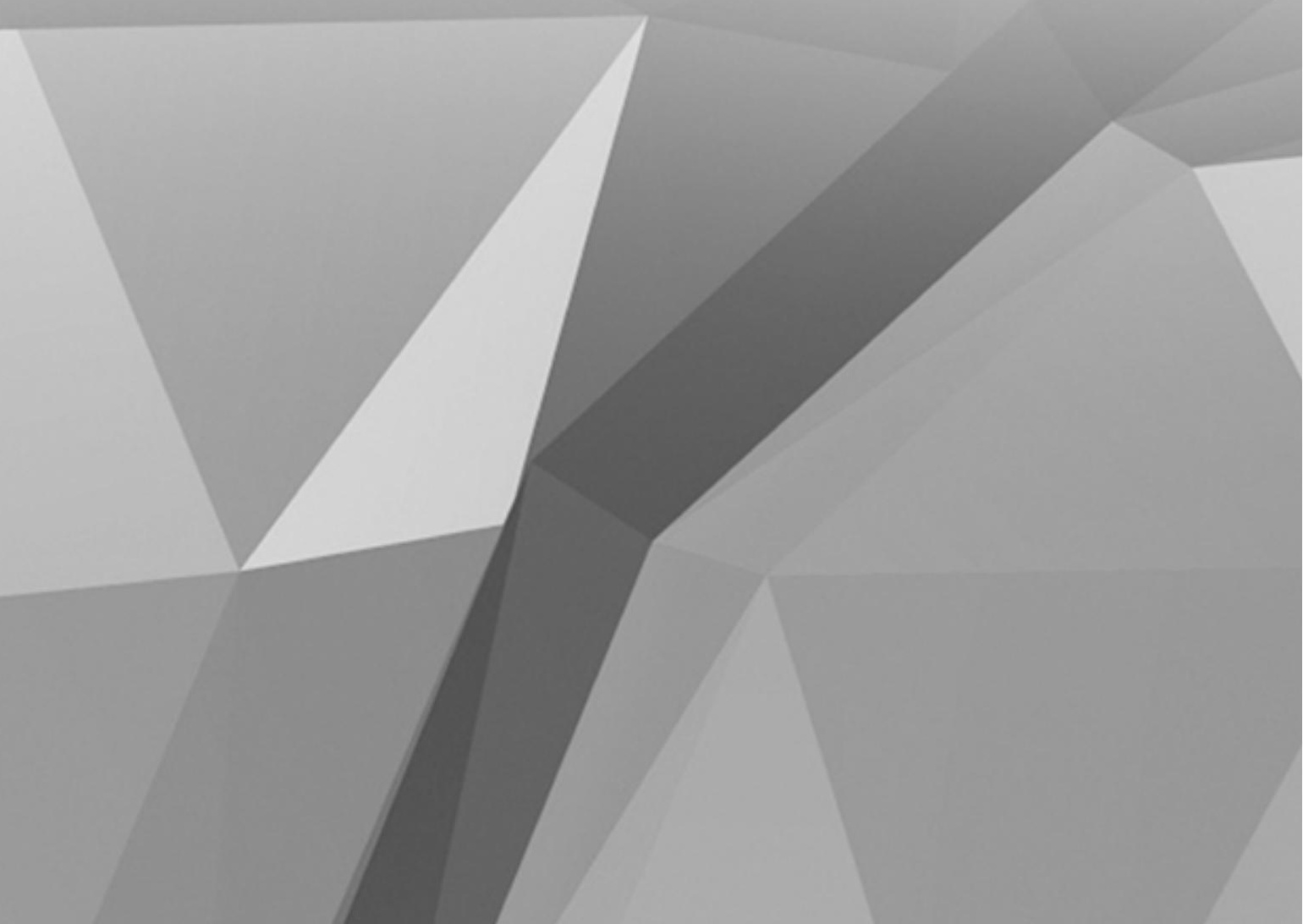




\section{Dankwoord}




\section{Dankwoord}

Zoals gebruikelijk, wil ik in dit laatste hoofdstuk iedereen bedanken die aan dit proefschrift heeft bijgedragen. Daar waar sommigen een concrete bijdrage leverden, stonden anderen meer op de achtergrond. Ook zonder hen had ik dit proefschrift niet kunnen afronden.

Allereerst wil ik graag mijn promotoren bedanken, prof. dr. Regina Beets-Tan en prof. dr. Geerard Beets. Bedankt voor jullie vertrouwen in mij en voor de mogelijkheid die jullie me geboden hebben om mijn eigen lijn te ontdekken. Jullie enthousiasme, passie en kritische noot hebben mij gestimuleerd te blijven nadenken en om buiten de gebaande paden te durven gaan. Het was een eer om onder jullie vleugels te mogen werken.

Doenja, wat had ik zonder jou als co-promotor gemoeten? Je bent een voorbeeld voor velen met je doorzettingsvermogen en relativeringsvermogen en je bereidheid om op ieder willekeurig moment van de dag mee te denken of te grasduinen. Ondanks de afstand tussen Amsterdam en Maastricht heb ik nooit het gevoel gehad dat ik er alleen voor stond. Bedankt dat je er voor me was, dat ik ongenuanceerd tegen je mocht ventileren, dat je me de vrijheid gaf om mijn eigen plan te trekken en dat je me dat laatste zetje gaf daar waar nodig.

De beoordelingscommissie, bestaande uit Prof. dr. Masclee, prof. dr. Backes, prof. dr. R.C. Dresen, prof. dr. van der Heide en prof. dr. Neumann, wil ik bedanken voor hun tijd en interesse om dit proefschrift te beoordelen.

Wetenschappelijk onderzoek doe je niet alleen. Ik wil dan ook alle co-auteurs heel hartelijk danken voor hun inzet en hulp bij het verzamelen van de data, het analyseren van de beelden, de statistische ondersteuning en de het redigeren van de tekst.

"Een warm bad", dat is de enige juiste benaming voor het fameuze Recteam. Of het nu een congresbezoek was, een uitstapje naar Disneyland of een nacht doorhalen in een karaokebar, jullie waren er in alle enthousiasme bij. Max, bedankt voor je reflecties en wijze woorden. Afgewisseld met een dosis droge humor was het altijd weer een feest. Monique, statistisch wonder, bedankt voor je waardevolle input en briljante voorspellingen. Luc en Milou, waarde voorgangers, het was een groot genoegen om in jullie voetsporen te mogen treden en de zorg voor de Wait\&See 
patiënten over te mogen nemen. Miriam en Britt, lieve kamergenoten, bedankt voor jullie geduld, washi-tape-schema's, uitbrak-op-de-bank momenten, lekkere koffie en veelvuldige lachmomenten. Joost en Stefano, één belletje was genoeg om ieder computer-gerelateerd probleem op te lossen, jullie hebben me meer dan eens gered. Rebecca, voormalig semi-arts en inmiddels waar onderzoeker, bedankt voor je hulp en gezelligheid bij de beruchte laatste loodjes. Marit en Lisa, jullie zijn de volgende generatie en al een heel eind onderweg. Heel veel succes en plezier met het afronden van jullie onderzoek.

Suzanne, paranimf, het is alweer zeven jaar geleden dat we elkaar leerden kennen in Manipal, India. Sinds die tijd zijn we nooit meer heel ver bij elkaar vandaan geweest. Via WESP/GEZP neurochirurgie en chirurgie allebei naar ANIOS, naar onderzoek om vervolgens allebei het roer om te gooien, voor onszelf te kiezen en ons hart te volgen. Het lijkt haast geen toeval dat onze wegen ook nu weer parallel lopen. Bedankt voor al je lieve woorden, je morele support, je hulp bij het tuinieren/klussen en de vele inspirerende koffiemomentjes. Ik vind het fijn dat je ook nu weer achter me staat.

Maartje, paranimf, wie had dat gedacht vijf jaar geleden op B4? Jij nog als verpleegkundige en ik als ANIOS chirurgie. Inmiddels tientallen etentjes verder, vele ervaringen rijker, borrelen met onze mannen en klussen in en om het huis. Ik vind het een eer dat je achter me staat. Bedankt voor je inspiratie, je immer oprechte interesse, je eindeloze klinische ervaring en je jaloersmakende organisatietalent. Ik kijk ernaar uit om straks weer met je samen te mogen werken bij de MDL.

Wat is een promotie zonder stille krachten op de achtergrond? De afdeling radiologie en chirurgie van het MUMC+, met in het bijzonder de dames van het secretariaat, de dames en heren van de balie, Jos Slenter, Janneke Houwers, Frans Bakers, Jeroen Kroll, onderzoekers en overige stafleden; jullie hulp was ontzettend waardevol. Julie Sijmons en Suzanne Pruijssers, bedankt dat jullie je kostbare tijd wilden spenderen aan het doen van wetenschappelijk onderzoek tijdens jullie geneeskunde studie. Ook GROW, met destijds prof. dr. Frans Rademakers aan het roer, jullie maakten het mogelijk dat ik ondanks de verhuizing van onze onderzoeksgroep naar Amsterdam een prettig thuis hield in Maastricht.

Collega's uit het Zuyderland; ook al waren jullie er nog niet tijdens mijn onderzoeksjaren, jullie steun en toeverlaat in de afrondende fase was meer dan 
welkom. Prof. dr. Ad Masclee, dr. Jacqueline Buijs en drs. Frank Stifft, heel hartelijk dank voor jullie vertrouwen in mij en voor de kans die jullie mij geboden hebben om mijn opleiding tot maag-darm-leverarts bij jullie te mogen volgen.

Dames van de "te gekke etentjes"; bedankt voor jullie wijze woorden, jullie steun en jullie heerlijke kookkunsten. Jullie ervaringen en onze diversiteit maken het altijd weer een interessante en gezellige avond!

Edward van Kempen, heel hartelijk bedankt voor je creativiteit en snelheid om dit boekje tot een prachtig vormgegeven resultaat te maken.

Dierbare (schoon)familie en vrienden; jullie zijn met velen, sommigen dichtbij en anderen helaas ver weg. Allemaal ontzettend bedankt voor jullie positiviteit, oprechte interesse en steun in de afgelopen jaren. Jasper, Jesper, Dirk, Kevin, Mitchell en Maurice; St. Jan mag dan al jaren achter ons liggen, het blijft bijzonder hoe we ondanks de vaak grote afstand elkaar altijd weer weten te vinden.

Lieve pap en mam, Stan, opa en oma; toen ik zei dat ik vier jaar achter een bureau ging zitten om onderzoek te doen, hebben jullie me uitgelachen en je hardop afgevraagd waar ik aan begon. In de afgelopen tijd heb ik meermaals gepoogd dit uit te leggen en ik hoop dat dit tastbare bewijs jullie iets wijzer zal maken. Bedankt voor jullie onvoorwaardelijke liefde, steun en vertrouwen.

Tot slot mijn lieve mannen, Koen en Ties. Koen, je hebt wel eens gekscherend gezegd dat ik het zonder jullie vast nog sneller had gekund. Maar weet dat ik deze tijd met jullie voor geen goud had willen missen. Ik kijk ontzettend uit naar een fijne en rustige tijd met ons viertjes in ons verbouwde thuis. 


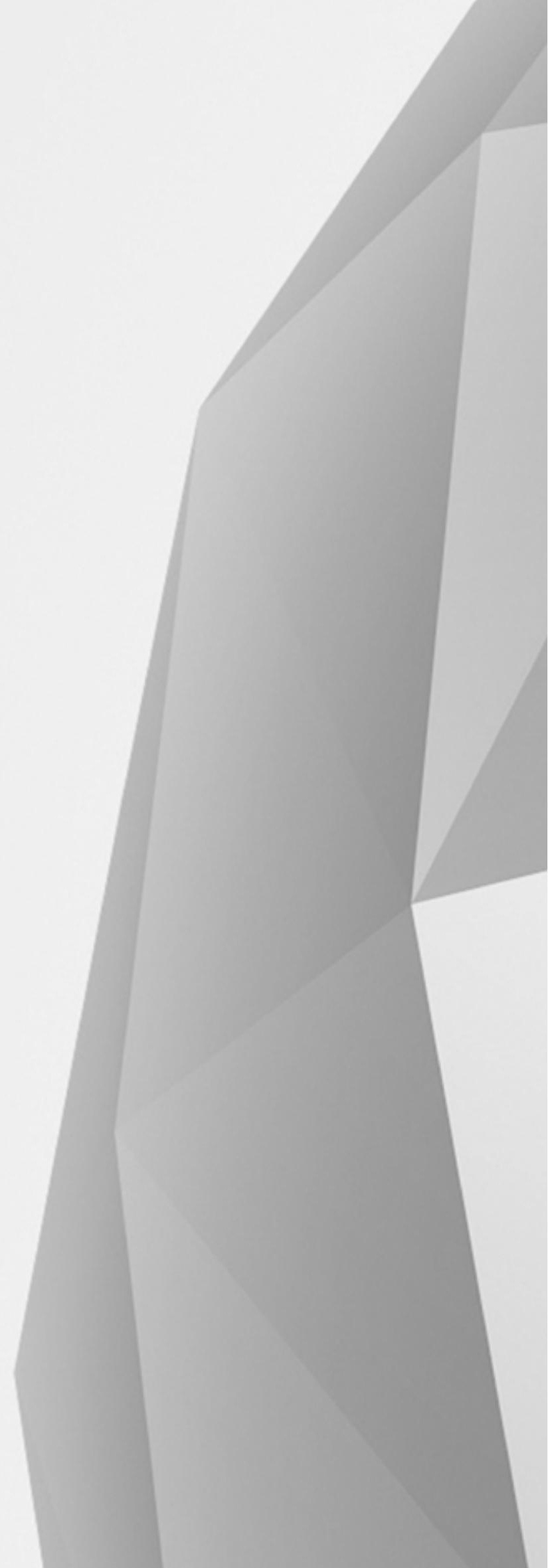


12. Curriculum Vitae 


\section{Gurriculum Vitae}

Rianne C.J. Beckers was born on March 29 1986 in Brunssum, the Netherlands. After obtaining her gymnasium degree in 2004 at Sint-Janscollege in Hoensbroek, she started a bachelor in Health Sciences with a major in Health, Policy and Management at the Faculty of Health, Medicine and Life Sciences at Maastricht University. In 2006 she started her medical study at the Faculty of Medicine at Maastricht University. In 2008 she finished her bachelor in Health Sciences while continuing her medical study. After obtaining her medical doctor degree in 2013, Rianne immediately started working as a surgical resident at the Maastricht University Medical Center. After one year of working in surgery, she started in 2014 as a PhD student at the GROW School for Oncology and Developmental Biology under supervision of prof. dr. R.G.H. Beets-Tan, prof. dr. G.L. Beets and dr. D.M.J. Lambregts.

In September 2017, she started her residency in Gastroenterology at the Zuyderland hospital in Sittard-Geleen and Heerlen under supervision of prof. dr. A.A.M. Masclee. 


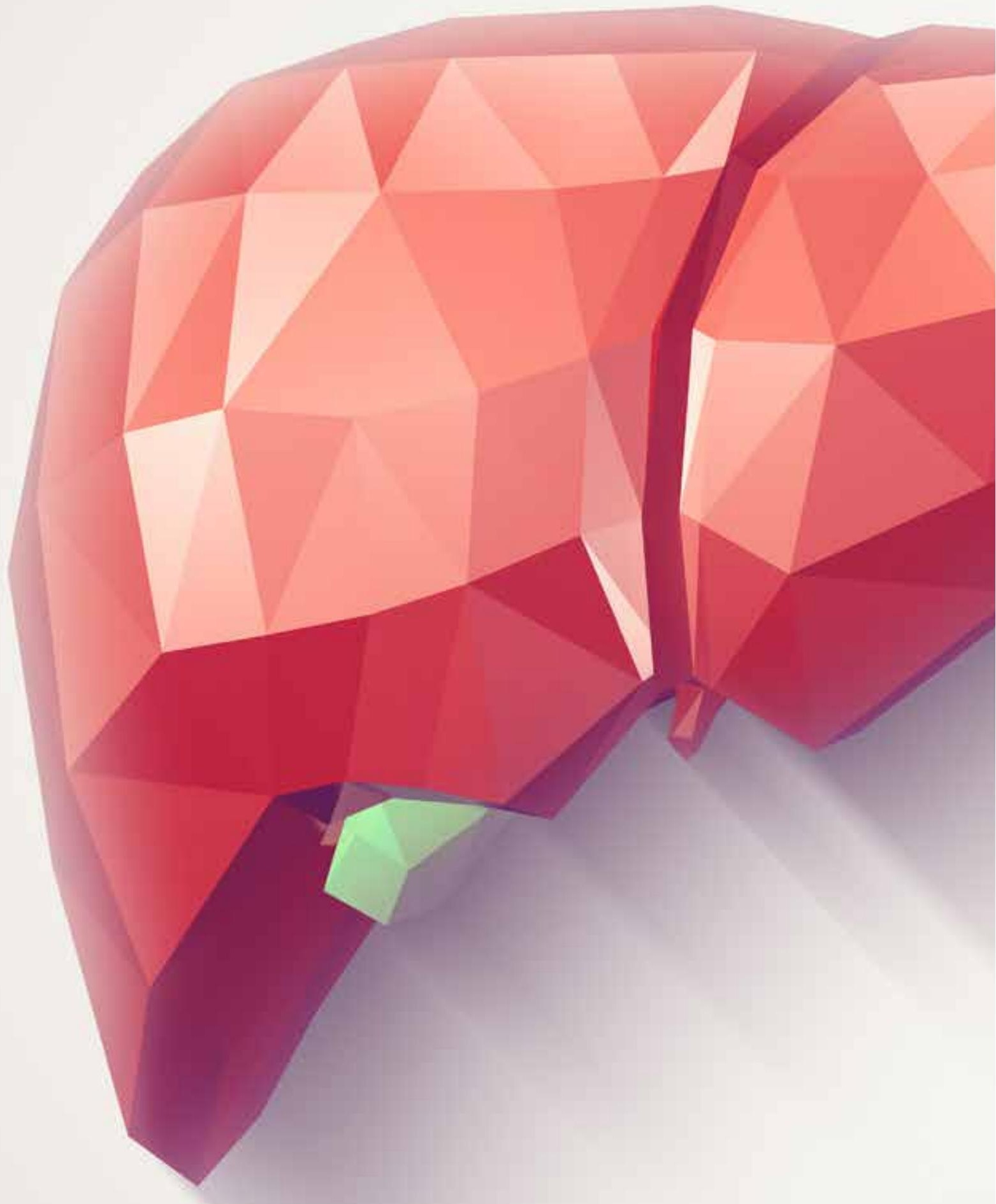

